Historic, Archive Document

Do not assume content reflects current scientific knowledge, policies, or practices. 

Reserve

aCiL6R4

. $M 6 B 5$

1380
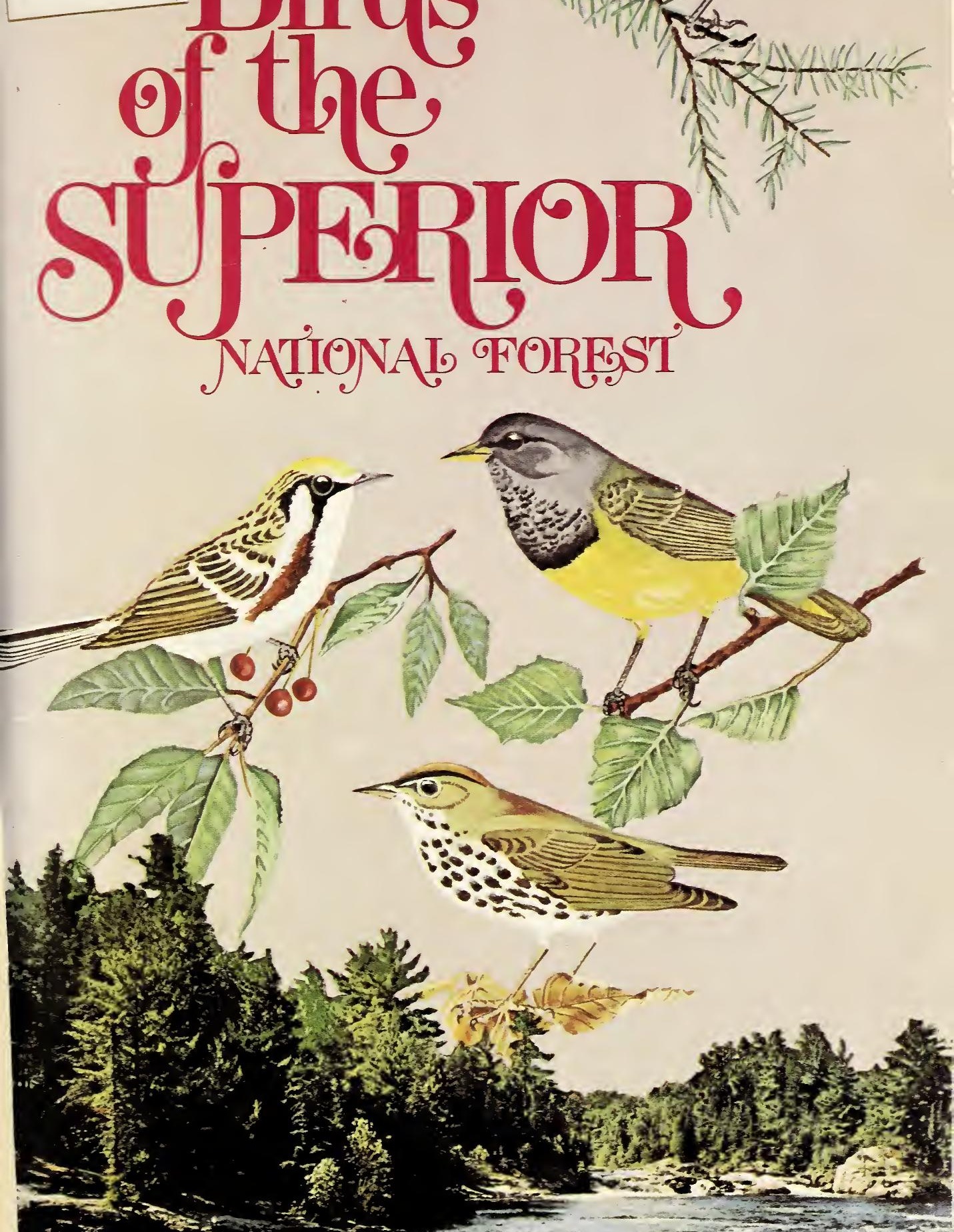


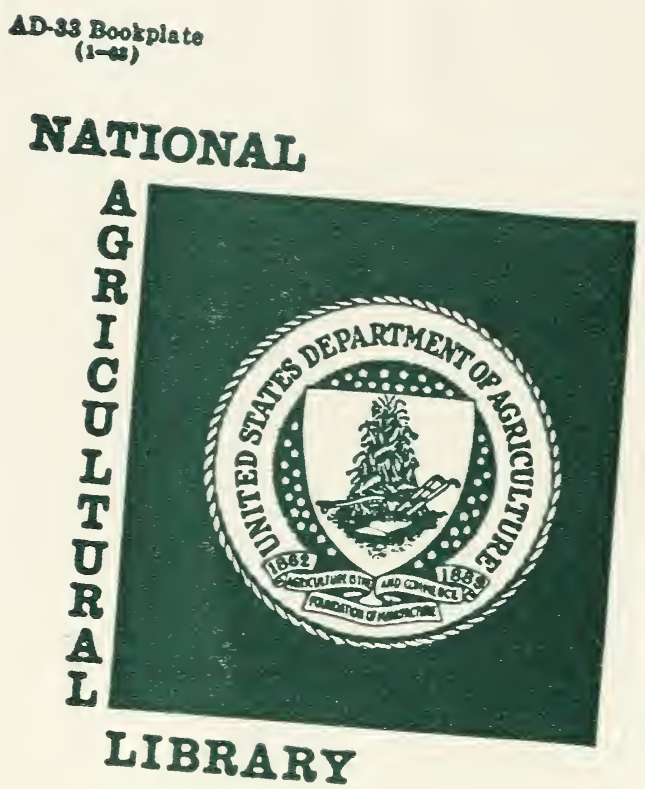




\section{U.S. DEPT. OF AGRICULTURAL NATIONAL AGRICULTURAL LIBRARY}

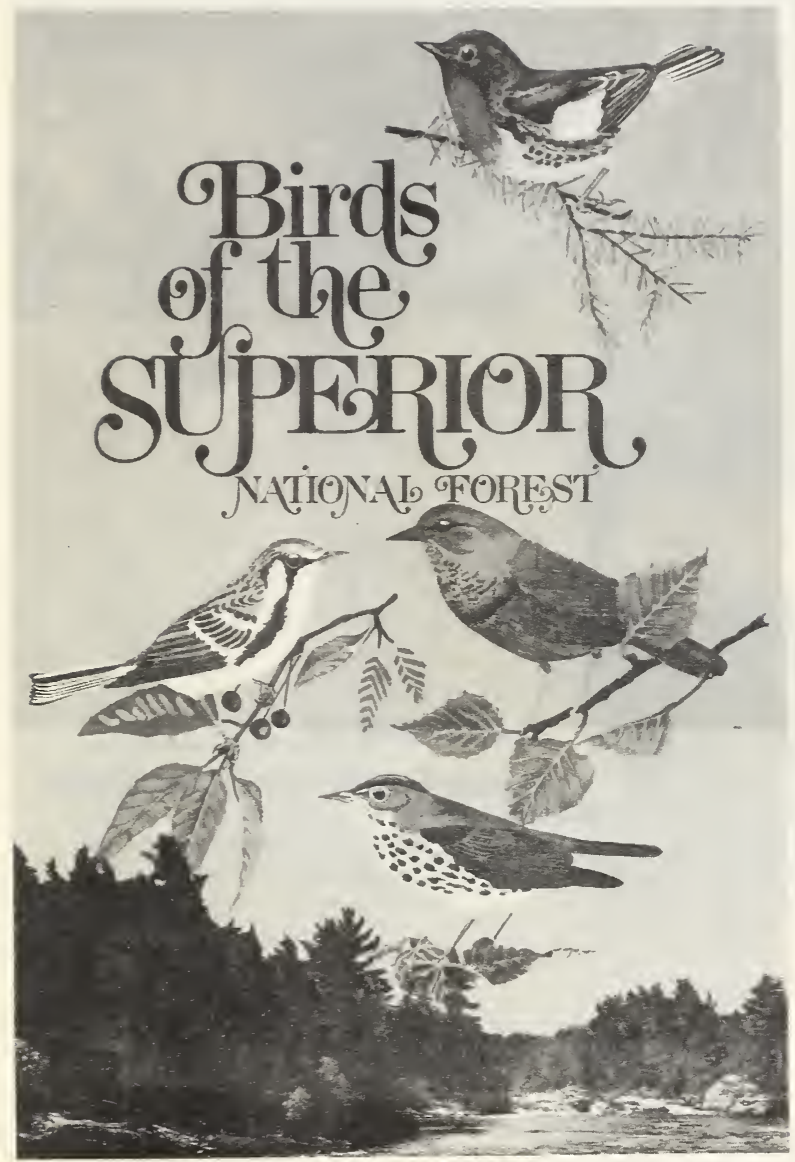

MAY 271980

CATALOGING $\equiv$ PREP.

The family, PARULIDAE, or wood warblers, includes 24 species on the Superior National Forest, an astonishing record of warbler abundance. These warblers are distinguishable primarily by their differing coloration, not size or shape. From top to bottom are the blackburnian, the mourning, the chestnutsided, and the ovenbird warbler. 


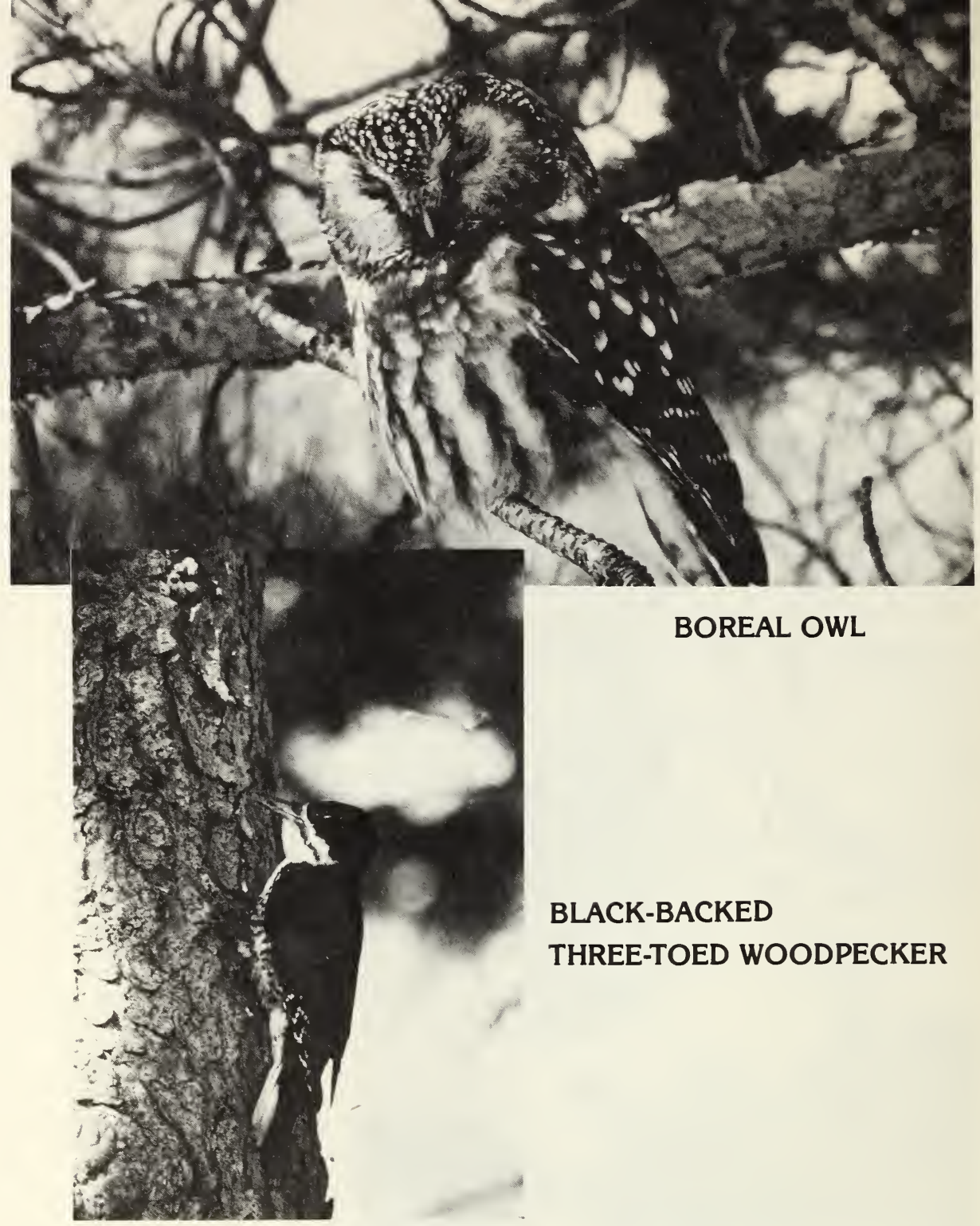

The boreal owl, Aegolius funereus, formerly listed as a rare winter visitor, invaded northeastern Minnesota in the winter of 1977-78 with 66 birds sighted. Even more astonishing was the first documented nesting of this species in the lower 48 States. A nest with five young was observed in the Superior National Forest in the summer of 1978. Fifteen additional singing males were heard on the Forest in the spring of 1978.

Although the black-backed three-toed woodpecker, Picoides arcticus, is considered to be rare on the forest, it is often common in spruce budworm infested areas or in the recently burned forest. This species is at the southern limit of its range in northern Minnesota. 


\title{
BIRDS \\ OF THE \\ SUPERIOR NATIONAL FOREST
}

\author{
Superior National Forest \\ Forest Service, U. S. Department of Agriculture \\ 1980 \\ By: \\ Janet C. Green \\ and \\ Gerald J. Niemi
}

Acknowledgments

Marjorie M. Carr provided the photographs of the black-backed three-toed woodpecker, bald eagle, common loon, white-throated sparrow, and common raven. Al Wolter provided the gray jay photograph. Don Goodermote provided the boreal owl photograph. Pictures in chapter 4 provided by G. Niemi and K. Siderits. Original cover art by Howard H. Hoffman.

For more information, contact:

Karl P. Siderits

Wildlife Biologist

Superior National Forest

P.O. Box 338, Federal Building

Duluth, Minn. 55801 


\section{CONTENTS}

Page

CHAPTER 1: INTRODUCTION ....................... 5

CHAPTER 2: BIRDS IN THE FOREST $\ldots \ldots \ldots \ldots \ldots \ldots \ldots \ldots \ldots . \ldots 7$

CHAPTER 3: DISTINCTIVE SPECIES $\ldots \ldots \ldots \ldots \ldots \ldots \ldots \ldots \ldots \ldots$

CHAPTER 4: BIRD COMMUNITIES $\ldots \ldots \ldots \ldots \ldots \ldots \ldots \ldots \ldots$

CHAPTER 5: BIRD FINDING $\ldots \ldots \ldots \ldots \ldots \ldots \ldots \ldots \ldots \ldots \ldots \ldots \ldots \ldots \ldots \ldots \ldots \ldots$

CHAPTER 6: ANNOTATED LIST $\ldots \ldots \ldots \ldots \ldots \ldots \ldots \ldots \ldots \ldots \ldots$

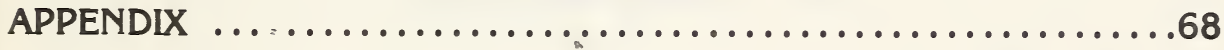

SELECTED BIBLIOGRAPHY $\ldots \ldots \ldots \ldots \ldots \ldots \ldots \ldots \ldots \ldots \ldots \ldots \ldots$ 


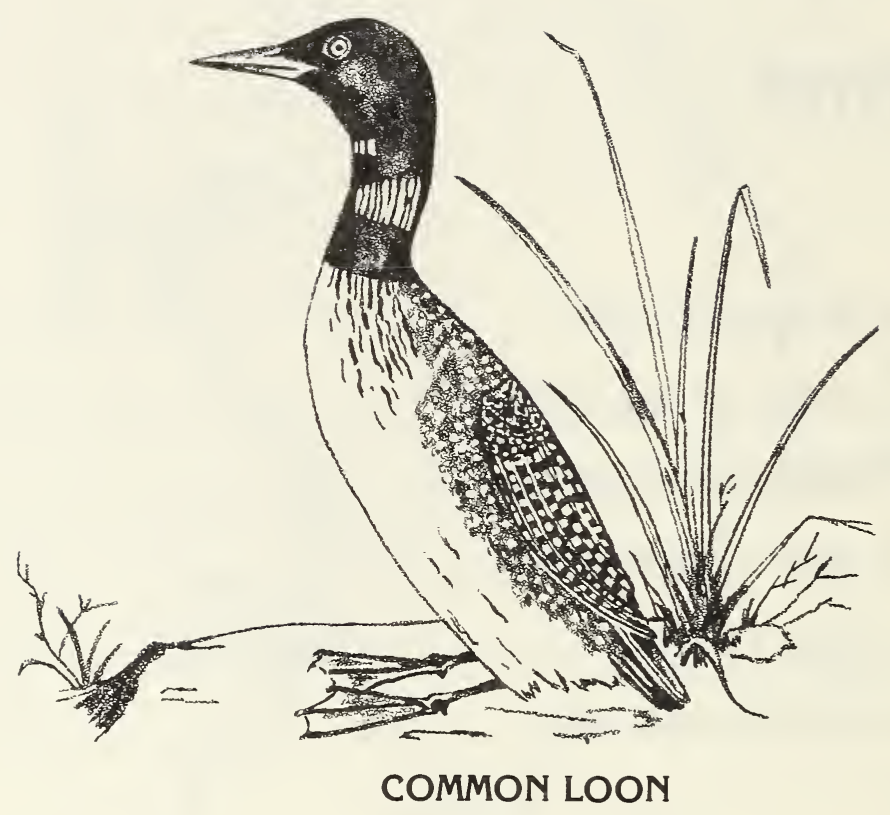




\section{BIRDS \\ OF THE \\ SUPERIOR NATIONAL FOREST}

\section{CHAPTER 1: INTRODUCTION}

\section{PURPOSE AND SCOPE}

Birds occur in a forest in a great variety of species and numbers, depending on the season and the habitat. This booklet describes the avian distribution in the Superior National Forest in northeastern Minnesota.

An interest in natural history is increasing among the outdoor public, while at the same time the professional biologist is becoming more aware of the need to manage for the total forest community. The intent of this booklet is to provide basic information about birds, especially during the summer nesting season, that will be of interest to both the amateur and professional. A section on the life histories of several common species is included to stimulate the interest of beginning naturalists. The section on bird finding is to help the traveling birder who wants to see particular species, usually northern coniferous forest birds, and does not have the time to explore the national forest extensively. The section on bird communities establishes a basic understanding of ecology and the relationship of birds to the forest environment. The annotated list is a review of the status of all bird species known to occur in the Superior National Forest.

Far more species of birds (155) breed in the Superior National Forest than any other class of vertebrate animal; birds account for 79 percent of the breeding wildlife species (mammals, reptiles, amphibians, and birds). Yet most people, whether they are a casual traveler or a serious biologist, are seldom aware of the existence of more than about 50 species, like ducks or hawks. More than two-thirds of the summer resident birds are often overlooked. These include about 100 small and inconspicuous songbirds that are often hidden by the thick foliage. Their presence is more easily noted soon after dawn during the early summer when they are the most active and in full song, but when few people are out and about. Seeing them requires much patient standing and stalking, a challenging task in a woods full of biting insects. If the psychological barriers of early rising and bedevilment by flying insects are overcome, the observer is rewarded by seeing many brightly colored birds, particularly the 24 species of wood warblers. Besides being beautiful and interesting, birds are accepted as good indicators of environmental diversity and health.

Learning the identifying marks and behaviors of forest birds is a first step. After this, the bird student often wants to know in what habitats they occur and whether there is a predictability to finding certain species in specific plant communities. A breeding bird census, conducted in May and June, is the method used to determine which species, and in what density, occur in a 
particular plant community, such as mature pine or bog. The observer takes to the field at sunrise and walks a predetermined course, listening to bird sounds and watching for birds, as the breeding males declare their territory by sight and sound. The references given for further reading are intended to aid in an overall understanding of avian and forest ecology.

\section{LOCATION AND LAND USE}

The Superior National Forest stretches 130 miles across the northeastern tip of Minnesota from the Lake Superior shore to the international border just east of Voyageurs National Park and Rainy Lake. It encompasses parts of Cook, Lake, and St. Louis Counties and contains 3,300,000 acres of land and water. The 1 million acre wilderness area along the Canadian border is the Boundary Waters Canoe Area (BWCA), famous for its abundant lakes. Almost 20 percent of the BWCA is water and all of it is publicly owned. The remainder of the Superior National Forest also contains many lakes. It is almost entirely forested, except for sporadic settlements along the western and southeastern edges of the national forest. Land ownership outside the BWCA is mixed; the bulk of it is owned by the county, State, and Federal governments. Most of the public, nonwilderness land is managed for a multiple of resources including timber, wildlife, water, range, and recreation. The major towns are resort communities along the North Shore and in the Ely-Winton area, with logging and mining also of importance to the local economy. Open country, once cleared for farming but rarely farmed today, is found inland from Grand Marais, in the Toimi-Brimson and the Britt-Angora areas, and around Ely and Winton. The main travel corridors are U.S. Highway 61 along Lake Superior, Minnesota Highway 1, and Lake County Highway 2 connecting the North Shore with Ely, and U.S. Highway 53 and Minnesota Highway 169 along the western edge of the Forest. Penetrating into the prime lake and resort country are the Gunflint Trail north of Grand Marais, the Fernberg Road east of Ely, and the Echo Trail northwest of Ely. In spite of their back-country sounding names, these roads are for the most part paved highways. The southern half of the Superior National Forest is laced with many gravel roads used for logging. The community of Isabella is the nucleus of the logging activity in the center of the National Forest.

\section{NATURAL SETTING}

The birds in the forest depend on the vegetation for nesting and feeding sites. The vegetation, in turn, is determined by such climatic factors as heat, light, and precipitation; earth forms and materials including slope, soil fertility, and drainage; and, historical disturbances like fire, logging, and disease.

The climate of the Superior National Forest is classed as mid-continental temperate with seasonal contrasts of hot, moist summers and long, cold, and snowy winters. Annual precipitation averages 27 inches, 60 percent of it in rain from early April to early November. The rest is in the form of snow, averaging 60 inches annually and covering the ground for about 150 days. The growing 
season varies from 100-120 days with the last killing frost as late as early June and the first fall frost in early September. Maximum summer temperatures may reach $95^{\circ} \mathrm{F}$ with a high monthly average of $62^{\circ} \mathrm{F}$ in July. Winter temperatures reach a low of $-45^{\circ} \mathrm{F}$ with a low monthly average of $12^{\circ} \mathrm{F}$ in January. The larger, deeper lakes usually freeze over in early December and break up in early May.

The Superior National Forest is geologically part of the ice-scoured Canadian Shield composed of Precambrian bedrock, 1 to 2.7 billion years old. Most of the hills and lakes are the result of the Wisconsin stage ice age that ended 10,000 years ago. The northern part of the Forest is alacially eroded landscape of rough topography and thin soils. In the southin and western parts of the Forest, the terrain is dominated by glacial features like drumlins and moraines. The land is characteristically rolling with little bedrock outcrop and much swamp. A special topographic feature in the eastern part of the National Forest is the North Shore Highland, where ancient volcanic rocks form ridges as far as 20 miles back from the Lake Superior shore and are flanked inland by extensive moraine. The local climatic effect of Lake Superior on this highland provides the only place within the Superior National Forest where the maple forest community flourishes.

\section{CHAPTER 2: BIRDS IN THE FOREST}

\section{ROLE OF VEGETATION}

The most striking aspect of the vegetation in the Superior National Forest is its variety. This reflects the Forest's position in a transition zone between two broad ecological formations - the northern boreal forest and the temperate deciduous forest.

The northern boreal forest occurs throughout the high latitudes of Canada. Here, precipitation is light and often in the form of snow, the growing season is short, and temperatures are highly variable. The vegetation in this zone is typically coniferous trees and deciduous asfen and birch.

The temperate deciduous forest occurs at the midlatitudes from the Great Lakes to New England, where precipitation is moderate, the growing season longer than in the boreal region, and temperatures warmer and not as variable. This zone, in which deciduous trees predominate, is found throughout the eastern United States. This transition area is called the White Pine-Northern Hardwoods Zone by ecologists and the Lakes States-St. Lawrence Forest by foresters. The boreal forest component includes the white spruce-balsam fir, jack pine, black spruce-tamarack, bog, and aspen-white birch communities. The more southerly influence is expressed in the sugar maple-yellow birch and white pine communities. It is common in the forest for the coniferous and deciduous species to be mixed in a very complex mosaic of forest communities.

In addition, the forest is constantly changing through a process called succession. When disturbance, such as fire or logging occurs, the "pioneer" 
species that require much light and are adaptable to more open growing conditions flourish. The aspen-birch and jack pine communities are early successional communities. In contrast, the more shade tolerant communities of northern white cedar and balsam fir are later successional communities. Cedar and firs often start to grow beneath the pioneer species and replace these short-lived species when they die. This process of succession is dependent on many factors including climate, soils, and topography. If succession were allowed to proceed, a climax community of cedar-white spruce-balsam fir would develop. However, the balsam fir is subject to periodic kills by outbreaks of spruce budworm, thus providing fuel for forest fires. It is doubtful that an extensive climax forest was ever present as fire was prevalent before 1900. Logging now takes the place of fire for stand renewal in most managed forests, and the early successional communities of aspen, birch and jack pine are dominant.

In visualizing a virgin forest (a forest affected only by nature), most people do not think of these early successional communities, but instead picture stands of huge red and white pines. Indeed, these existed to a much larger extent in the pre-logging era. These old-growth stands of red and white pine were the prize lumber of the logging era that began in the late 19th century in northern Minnesota. The big pines are mostly gone today except in parts of the BWCA. Replacement stands of red pine and white spruce are now managed largely for sawtimber. Blister rust kills white pine so it is no longer a commercially viable species.

Plant ecologists and foresters think of the forest in terms of its species composition while wildlife biologists and birders visualize herbaceous, shrub, and canopy layers. It is not so much the particular tree species that determines bird habitat but the vegetative profile or structural diversity (age, size, and density of the vegetation). Diversity in the vegetative profile can be depicted in a vertical plane by layers (bare ground, herbaceous, shrub, subcanopy, canopy) and in a horizontal plane by patches (clumps of trees or shrubs of different age or form). Birds require vegetation as sites for nesting and foraging for their food. In general, the greater the diversity in the vegetative profile, the greater the opportunity for fulfilling the nesting and food needs for a variety of bird species. Structurally simple sites like recent clearcuts and open bogs generally have limited bird populations. Closed-canopy, single-species conifer plantations and even-aged deciduous stands with little understory also do not provide much structural diversity, and are consequently poor in birdlife. A richer and more numerous bird population is found in more complex communities. Some examples would be 1) shrub swamp (alder and willow wetlands) with patches of cedar and deciduous trees and 2) scattered old growth pine with a subcanopy of aspen-spruce-fir and a well developed shrub layer.

Much research remains to be done on the significance of birds in energy and nutrient cycles and on their regulatory role as predators on insect populations. 


\section{BIRDS DURING THE SEASONS}

Winter: There is a seasonal rhythm to the fluctuations of bird life in the forest that is dependent primarily on the availability of food. The severe climatic conditions and the scarce food resources of winter means that very few birds can survive. Most species migrate, while even those that are present all year sometimes wander in search of food. Snow-covered deciduous woods in late winter are particularly devoid of birds. Conifer forests offer more in the way of shelter and food, but even there birds are scarce unless cones are prolific, inviting an invasion of winter finches. Winter population studies conducted on foot in the Superior National Forest in a variety of communities produced an average of six birds for 5 hours in the field during a year of very low numbers of winter finches and 33 birds for 5 hours in an average finch year. The populations of all bird species in northern areas, whether resident or winter visitors, are cyclic, with numbers varying from year to year based on the nesting success of the previous breeding season, weather conditions, and the amount of food available.

The common raven, a scavenger on carcasses from predator and road kills, is the most conspicuous winter bird in the national forest; its raucous cries often are the only sound to pierce the cold winter air. In the absence of flocks of nomadic winter finches, most observations are of chickadees (boreal, black-capped) and woodpeckers (pileated, hairy, downy, black-back three-toed), two families that search out insect larvae hidden in wood and bark crevices. Other permanent residents that could be encountered in the winter woods include: spruce and ruffed grouse; great horned, barred, and great gray owls; Northern three-toed woodpecker (scarce), gray jay, white-breasted and red-breasted nuthatches. The blue jay and common crow, permanent residents farther south, depart for the winter except in the vicinity of towns. In fact, food is at such a premium during the winter that resident birds are most numerous around settlements, attracted by the artificial supply of food at feeders.

Resident birdlife during the winter is augmented by erratic influxes of species from farther north or west. Why these invasions occur is not clearly understood, but they probably correlate with food supplies in breeding and wintering territories and with reproductive success during the preceding nesting season. Where the birds come from is also not precisely known. Most species originate in the northern boreal forest-tundra zone, but it is possible that some invasions come from large local populations. With all these uncertainties, it is difficult to predict the timing and extent of the nomadic wanderings of winter birds. Usually a few goshawks and northern owls are found every year but big invasions seem to occur in about 10 year cycles. Two other predators, the snowy owl and northern shrike, are more regular in occurrence, although their winter numbers also vary. Small flocks of most of the northern finches and waxwings are also present each year, with big influxes occurring every 2 to 3 years. The species regularly involved in winter invasions include: vertebrate predators - goshawk, great horned owl (minor), hawk owl, barred owl (minor), great gray owl, and boreal owl; berry eaters 
(mountain ash mostly) - American robin, Bohemian waxwing, and cedar waxwing (minor); seed eaters - evening grosbeak, purple finch (minor), pine grosbeak, hoary redpoll, common redpoll, pine siskin, red crossbill, and whitewinged crossbill.

There are other less common winter visitors that can sometimes be found in the Forest or along the shore of Lake Superior. Their status is described in the annotated list.

\section{Migration}

The migration of birds is a spectacular and interesting phenomena. What causes the little black-and-white warbler to leave the Superior National Forest in early fall and migrate to the Caribbean when a similar species, the redbreasted nuthatch, will stay in the forest all year long? How do birds navigate between two places, thousands of miles apart, returning to the exact same place winter and summer?

The modern explanations for bird migration have focused on 1) the onset of cold weather, 2) the lack of food on the breeding grounds during winter, and 3) a genetic response. Migration has probably evolved independently in different bird populations responding to different environmental circumstances. The stimulus for initiating migration is due mostly to the change in day length, whereas the actual time of departure from a given area is due to local weather conditions. Favorable weather, especially clear skies and sustained winds, aid in the efficient passage from one area to another.

After the winter invaders return north at the end of March, there is a quiet time in the woods before the first wave of migrants return in middle or late April after the snow has melted. These early flocks are composed of passerines like the brown creeper, winter wren, hermit thrush, kinglets, and yellow-rumped warbler. They have spent the winter in the central and southern United States. Waterfowl, blackbirds, and hawks also migrate at this time. The second spring migration peak occurs in mid to late May and involves the passerines that have wintered in the tropics or sub-tropics, mostly warblers, vireos, and fly catchers. Although there is a trickle of insect-eating species returning to the national forest throughout May, most do not come until late in the month when the supply of food is more dependable. The latest waves are composed of species that will nest further north in the boreal forest. They continue to migrate throughout early June. Sometimes it is difficult to separate migrating individuals from breeding individuals since different populations of the same species are involved in both activities at the same time. Shorebirds that nest on the tundra also have a late migration peak, sometime around the first of June.

Shorebirds are the first migrants to return in the fall, with some arriving in mid-July. The fall migration period for all species combined is twice as long as in the spring. It extends for 5 months, into mid-December. The first fall peak is between mid-August and early September when most of the warblers, vireos, thrushes, and flycatchers are once again migrating south. Most shorebirds also pass through at this time. The second peak is from the end of September 
through mid-October and involves the crows, blackbirds, and sparrows. The waterfowl move out of the Forest in late October through mid-November as the shallow lakes and rivers freeze over. Early flocks of northern finches may start to arrive any time after October 20 . Theoretically, there are more birds moving through in the fall due to the recent production of young, but the migration does not seem as intense as in the spring because the birds gradually depart over a longer period of time.

The schedule of migration outlined above is very weather dependent, and the seasonal peaks may vary as much as 2 weeks if the weather patterns are unusually favorable or adverse. The national forest has little suitable habitat for shorebirds or waterfowl so these families do not contribute much to the migration. Waves of passerines can be found in any wooded situation, but because the forest environment is so extensive, they are not as visibly concentrated as in agricultural areas further south. More information on bird finding during migration is presented in Chapter 5.

\section{Summer}

Warblers and vireos comprise about half of the songbirds nesting in the national forest. They spend a remarkably short time on their northern breeding grounds, 3 months at the most, and actual nesting takes about 6 weeks long enough to produce one brood of young. Upon first arrival in late May, the birds rapidly set up territories. Singing male activity is most conspicuous from about June 1 to July 4. Most young are fledged by mid-July and the woods then are very quiet in contrast to the territorial songs heard only a few weeks before. Wandering flocks of post-breeding birds, usually family groups of warblers or chickadees, are encountered beginning in mid-July. Migration really gets underway by late July or early August after the birds have molted.

The emphasis of this booklet is on the requirements of forest-dwelling birds during the summer season. The chapter on bird communities places the species in their preferred habitat, while the appendix lists their nesting and feeding strategies as well as giving some quantitative information on abundance for "common" species based on the U.S. Fish and Wildlife Service's Cooperative Breeding Bird Surveys. Habitat density data generated in the Regional Copper-Nickel Study Area (Hoyt Lakes to the South Kawishiwi River) gives some indication of the avian density of selected habitats. The figures average 1,295 pairs per square mile $\left(\mathrm{mi}^{2}\right)$ for recent clearcuts and open bogs; 1,729 to 2,223 pairs per $\mathrm{mi}^{2}$ for closed-canopy deciduous and coniferous upland stands, and 2,470 to 3,705 per $\mathrm{mi}^{2}$ in shrub or young deciduous communities.

One special community that has not been mentioned in any of these studies is the spruce budworm infested balsam fir community. When outbreaks of this insect occur, several bird species respond by dramatically increasing their populations in the affected area. The Tennessee, cape may, and bay-breasted warblers and the evening grosbeak are well-known for this response. However, no population counts have been made in this community in the Superior National Forest. The last spruce budworm outbreak occurred in 
the Two Harbors Ranger District in 1974-75.

Table 1 accompanies the annotated list and gives the abundance of breeding birds. There are a few species on that list classified as very rare whose actual nesting is not documented - northern three-toed woodpecker, Wilson's warbler, rusty blackbird, and red crossbill. They are near, or at the margin, of their range on the Forest and their breeding needs confirmation. A few other species have been reported in summer and might nest since they too have breeding populations not far to the north in Canada - solitary sandpiper, hawk owl, orange-crowned warbler, pine grosbeak, and white-winged crossbill. Evidence for their breeding is too slim to include them as summer residents now.

Finally, there is a category of breeding residents for whom the Superior National Forest is the center of their breeding range in Minnesota. These are termed indigenous species and include:

Goshawk
Sharp-shinned hawk
Merlin
Spruce grouse
Saw-whet owl
Boreal owl
Black-backed three-toed
woodpecker
Northern three-toed woodpecker
Yellow-bellied flycatcher
Olive-sided flycatcher
Gray jay
Boreal chickadee
Brown creeper
Winter wren

Solitary vireo
Philadelphia vireo
Tennessee warbler
Cape May warbler
Black-throated blue warbler
Bay-breasted warbler
Palm warbler
Northern waterthrush
Connecticut warbler
Wilson's warbler
Rusty blackbird
Evening grosbeak
Red crossbill
Dark-eyed junco
Lincoln's sparrow

Solitary vireo

Philadelphia vireo

Tennessee warbler

Cape May warbler

Bay-breasted warbler

Palm warbler

Northern waterthrush

Connecticut warbler

Wilson's warble

Rusty blackbird

Evening grosbeak

Red crossbill

Lincoln's sparrow

\section{CHAPTER 3: DISTINCTIVE SPECIES}

The northern bald eagle, Haliaeetus leucocephalus, has recently received an endangered status in most of the northern United States and a threatened status in five States, including Minnesota. The eagle population on the Superior National Forest is stable with 23 active territories producing 40 young in 1979. A majority of the eagles are in the prolific lake country of the BWCA. The Forest Service has a very intensive program of eagle management including nest census and regulations for protection of the nest and adjacent territory on national forest lands.

The-osprey, Pandion haliaetus, depends almost entirely on fish for its diet unlike the bald eagle which often scavenges for meat. Osprey characteristically build a huge nest, over 6 feet in width, on top of a snag. Repeating aerial censuses are usually difficult as these nests are subject to destruction by 

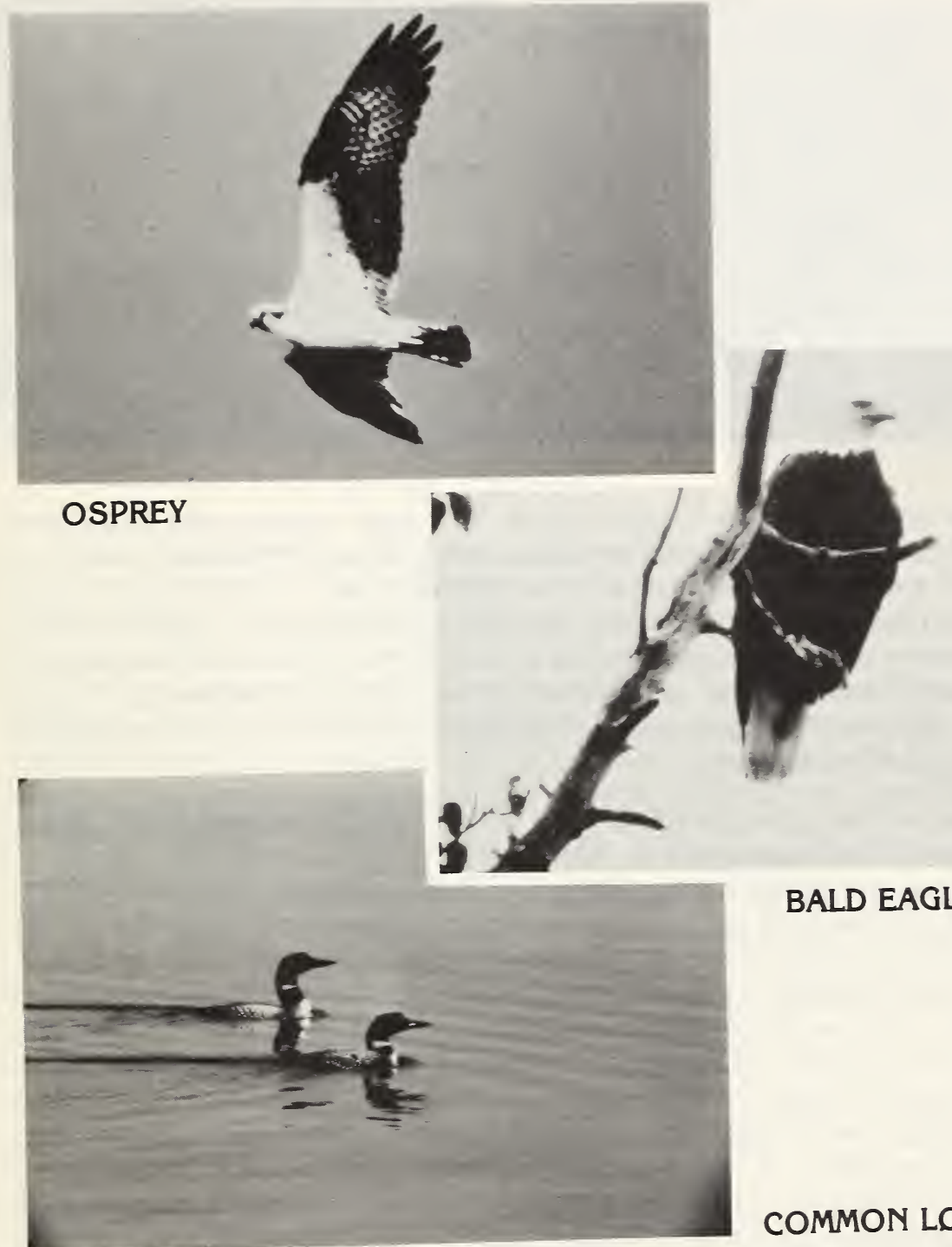

BALD EAGLE

\section{COMMON LOONS}

the winter storms. Osprey and eagles may build several nests within their territory with individual occupancy changing after 3 to 5 years. During the nesting season, active and unused nests in an active territory are repaired and green pine boughs are placed in the nests. In 1979, 16 osprey territories were active with 24 young fledged.

The common loon, Gavia immer, a holartic species, is commonly found on lakes, especially in the northern part of the forest. Designated the State bird of Minnesota, the loon has a spectacular breeding ritual involving many calls and displays on the water. 


\section{COMMON RAVEN}

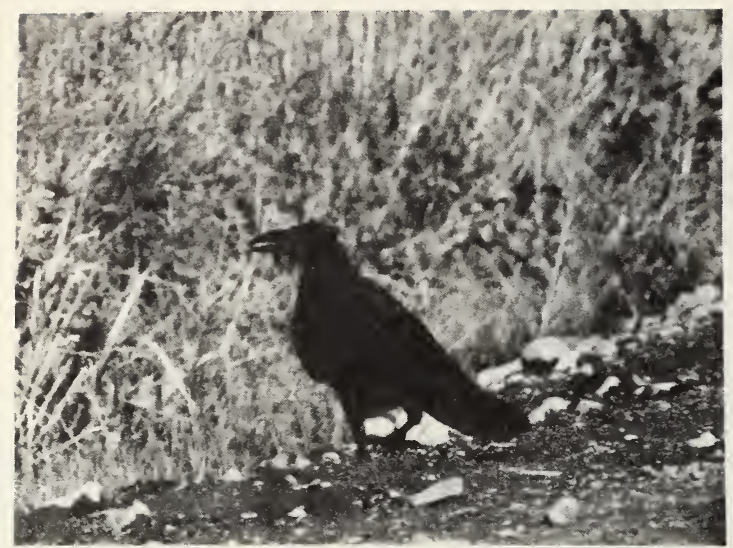

\section{WHITE-THROATED SPARROW}

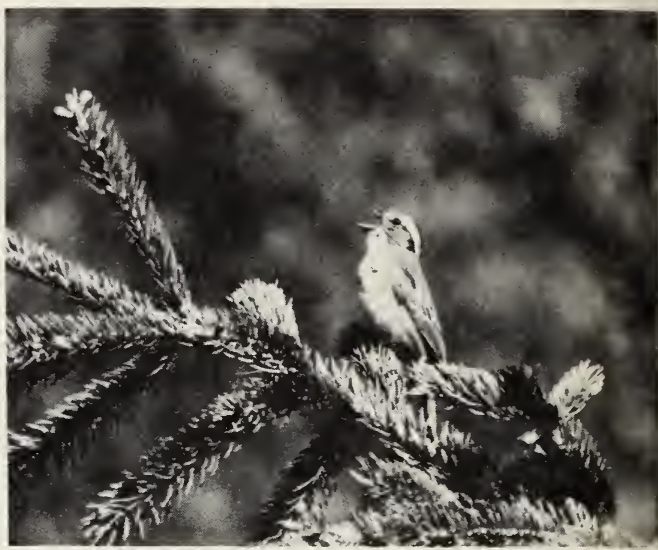

The common raven, Corvus corax, is a large conspicuous black bird and is most often encountered by visitors to the Superior National Forest as it feeds on a roadside killed animal, or as it slowly soars over fields and forest. The raven stands about 20 inches high and has a wingspan of about 4 feet. The best way to identify a raven from a crow is by the rounded tail feathers and by its loud hoarse "croak", in contrast to the square tail feathers and "cawcaw" of the crow. The raven is also larger than a crow, but this is often difficult to distinguish in the field.

The raven is a permanent resident of the Superior National Forest, which constitutes its primary range in Minnesota. The raven feeds on a variety of food items, but mostly on the remains of hares, squirrels, skunks, and deer. The raven is also believed to follow wolf packs where it will scavenge on the remains of a wolf killed carcass. The raven ranges over a wide area and, thus, can be encountered in many different habitats. Its nesting habitat, however, is most frequently on a cliff ledge or at the top of a large pine or spruce tree. The nest is about 4 feet in diameter and is usually placed very high on the cliff or tree, being quite inaccessible to predators. Four or five eggs are generally laid in early March and incubation lasts about 3 weeks. The young remain in or near the nest about 4 to 5 weeks. Thus, fledging takes place in late May or early June. Following the fledging stage, the raven is generally nomadic and feeds throughout the forest. With the approach of cold weather, the species may wander to the south, but it only occasionally occurs as far south as the Minneapolis-St. Paul area.

The white-throated sparrow, Zonotrichia albicollis, is a common breeding bird in theForest. This sparrow is commonly found in shrub and logged areas, perching on a branch above the dense understory. It is easily recognizable by its distinctive song, which is one low note followed by four high whistles. It is commonly referred to as "Old Man Peabody ... Peabody ... Peabody." The nest is constructed of grasses in a concealed location on the ground. 


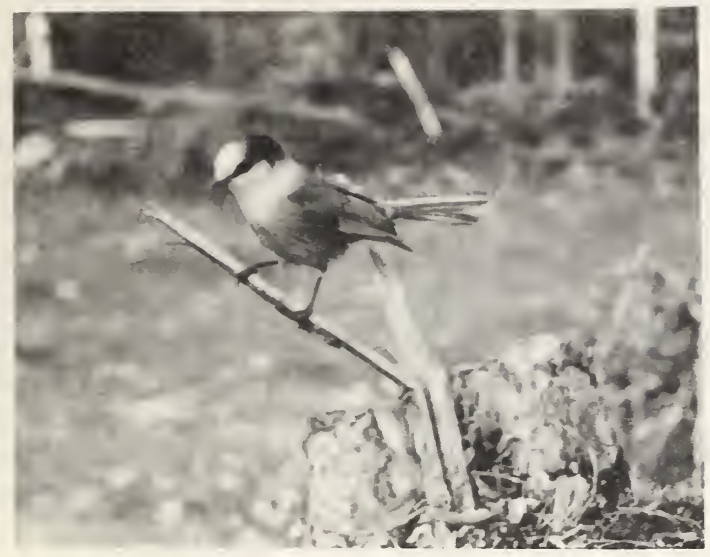

The friendly gray jay, also known as Canada jay, whiskey jack, lumberjack bird, or camp robber, is well known to the people who visit the Superior National Forest. Many encounter the species as it snitches a tidbit of food from the picnic table or even directly from a sizzling frying pan on an open campfire. The gray jay can be found throughout the Superior National Forest wherever evergreen forests of spruce, tamarack, pine, or cedar occur. It is, thus, a species very indicative of the boreal flavor of the Superior National Forest. Like many of the boreal bird species, the gray jay is very tame and generally unafraid of people.

Since this species generally nests during the months of March, April, and May, it is one of the earliest nesting birds in the forest. The nest is placed about 4 to 12 feet up in an evergreen tree and is built of twigs, strips of bark, grasses, and moss. The eggs are laid in late March and hatch in early April. The incubation period is about 16 to 18 days and the young remain in the nest about 15 days. The young are usually able to fly by late April. From early May through the summer, a family of gray jays including two adults and from one to five sooty-colored, juvenile-plumaged young can be found roving through the forests in search of food. With the approach of autumn, the young birds undergo a molt and then obtain the adult plumage. In the fall, the gray jay continues its nomadic wandering and some individuals may move south or west but few venture far from the boreal forest. Most gray jay individuals stay in the Superior National Forest all winter where they can be found in the forests, bogs, and occasionally visiting feeders in towns. Like many boreal bird species, the gray jay population varies yearly. One year the species will be quite common and many will be sighted away from the boreal forest, while the next year they are difficult to find even in suitable habitats. 


\section{CHAPTER 4: BIRD COMMUNITIES}

A major objective of this booklet is to provide an ecological approach to birding and the correlation of birds with their habitat. The forest is a complicated system with many interactions among plants, animals, climate, and soil. We have simplified this system by classifying several major forest communities for the purpose of discussion. Birds probably do not recognize communities as we do, but the following community classification has proved useful in managing the wildlife of our forests. Some species are very selective and restricted to a particular community, while others find their needs in several communities.

Fourteen forest communities are identified in this chapter on the basis of

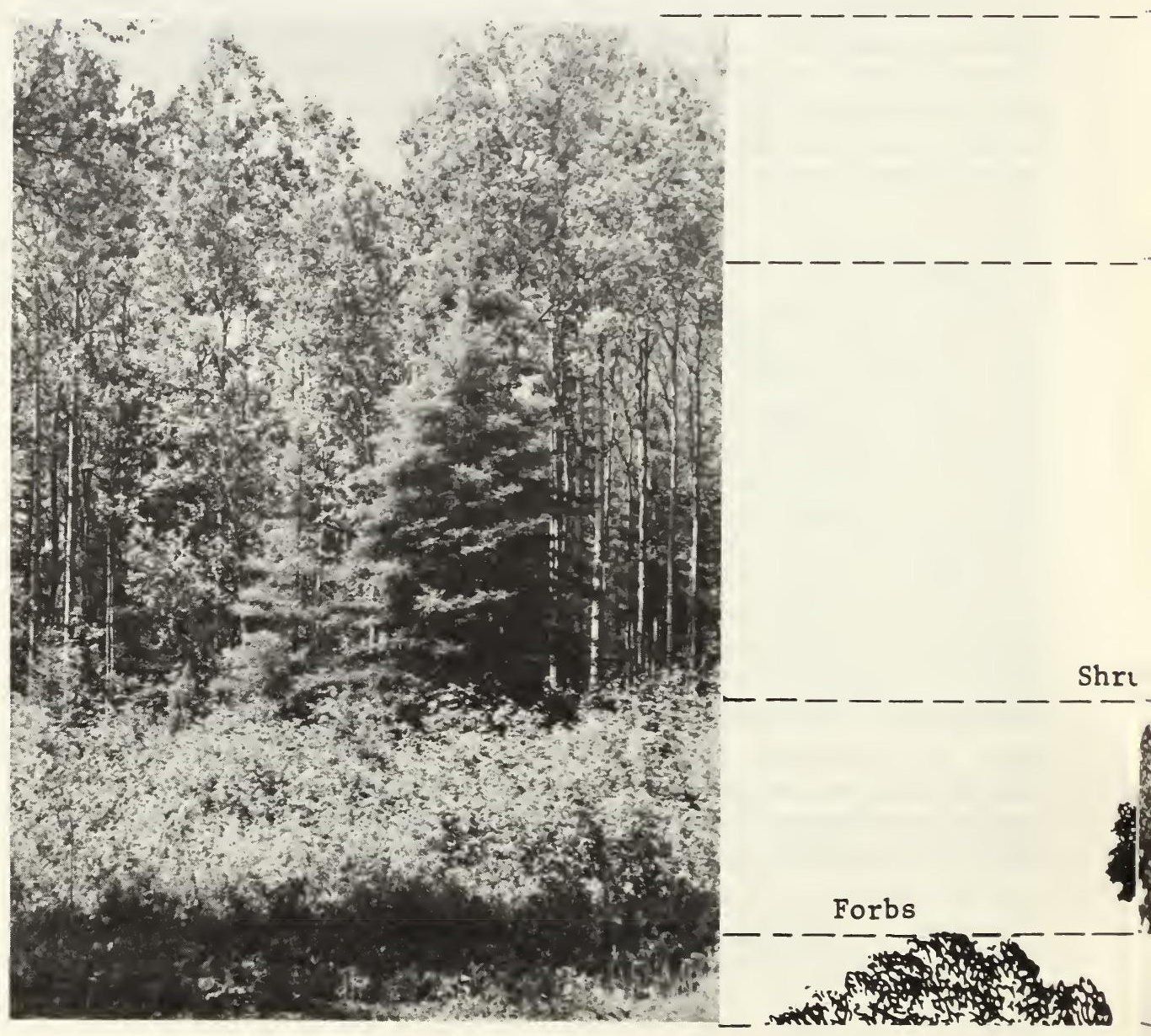


In classification, a species is placed into a community for which its behavioral and morphological adaptations are best suited. For example, an ovenbird has relatively long legs and a large bill for a warbler. The ovenbird is best adapted to walking and feeding on the ground or on the larger, lower branches of trees. The blackburnian warbler, in contrast, with short legs and a small bill, is best adapted to living near the top of conifer trees. An extreme example is the loon which is highly adapted to the water environment. The loon can hardly walk on land because its legs are positioned far to the posterior end of its body. But because of this leg position and its sleek body contour, the loon can penetrate deeper into lakes than most diving ducks. Thus, a species is found in a given habitat because its ancestors adapted a more efficient use of one habitat over another. Remember, this process is not static but rather dynamic, where individuals of a species are continuously attempting to colonize other presumably suboptimum areas. This is why species are found in areas that are not considered typical breeding habitats.

We must also consider what the reproductive success of each species would be if every year all species breeding in the forest randomly selected. nesting areas. If this were true, then species would be continually competing with one another for food, shelter, and nest sites. This would generally be an inefficient process. Thus, birds select breeding communities based on vegetative structure, allowing them to spend more time obtaining resources necessary to live and to reproduce. Most birds return to the same breeding area year after year. Because the species was raised in the specific habitat, it is more familiar in how to procure food, shelter, and nesting sites.

Another facet to the understanding and appreciation of bird communities is to identify the role of a particular species. The term "niche" is a composite of all the activities of a species. It includes: Where (canopy, subcanopy, shrubs or ground) a species conducts its activities; what (seeds, insects, berries) a species eats; how (flycatching, probing the bark of trees, or feeding on leaf litter) a species obtains its food; and when (late spring, summer) a species uses the community. Thus, the species niche allows many species to inhabit the same community.

Photographs have been included to aid in the description and recognition of each bird community. Obviously, there can be much variation from this "average appearance" but the photographs are intended to aid your understanding of the vegetative structure concept and help you find the various communities in the field. The vegetation of a community is described in terms of strata and typical plant species. Description of bird species found in the community is limited to three basic levels. First, the primary species that are very common or abundant and conspicuous breeding birds of the community that can be found with reasonable searching effort by a competent observer. Second, secondary species that also occur in other communities, but are often found breeding in the specific community being discussed. Species that are inconspicuous, may not always occur in the community, or require considerable effort to find may also be described. ldeally, these categories should be based on species population densities in the community; 
however, these data do not exist at this time.

The wildlife management program on the Superior National Forest has the maintenance or improvement of plant community diversity as its major objective. Maintenance of a variety of plant communities provides for wildlife species diversity. As a community increases in acreage, wildlife species that have feeding, nesting, and cover needs not found in the community will find unsuitable habitat and leave the area. A major consideration of this management program is to identify the variety of communities before management occurs. This allows the biologist and the forester to analyze the alternatives for management of a given area in a biological framework. Naturally, social and economic considerations are part of an ecological approach and must also be considered.

\section{PINE COMMUNITY}

The mature pine community is generally composed of large red, white, or jack pine up to 100 feet tall. White and red pine are often present as a supercanopy high above another community. The subcanopy is generally quite sparse, but often is composed of paper birch, balsam fir, black spruce, and mountain ash. The shrub layers are poorly developed and are often composed of mountain maple, beaked hazel, and juneberry. Ground cover is typically sparse with a dense mat of bunchberry, wintergreen, and pine nee-

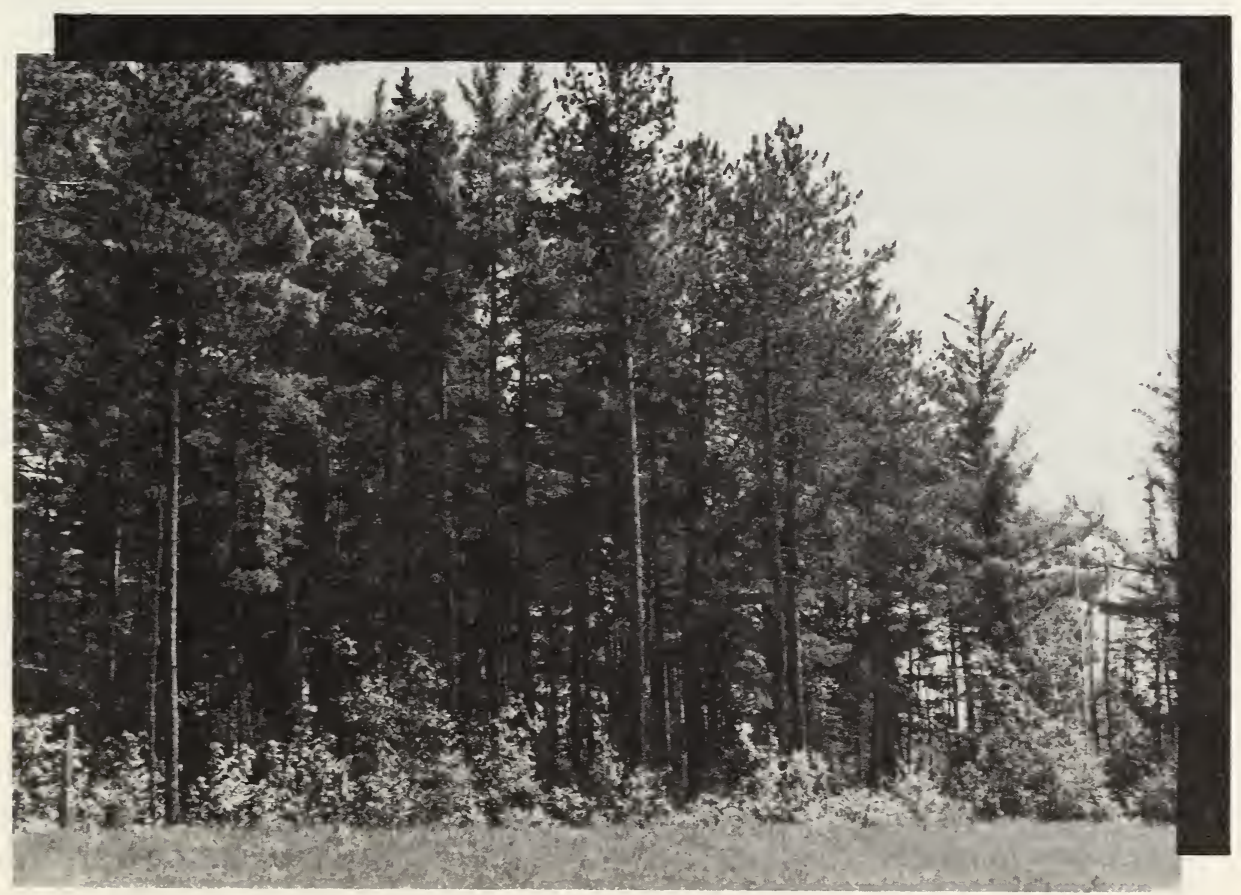


dles. Lichens and mosses are often predominant herbaceous or ground cover plants.

Primary breeding species of this community are:

Red-breasted nuthatch

Brown creeper

Hermit thrush

Golden-crowned kinglet

Ruby-crowned kinglet

Secondary breeding species include:

Sharp-shinned hawk

Yellow-bellied sapsucker

Least flycatcher

Eastern wood pewee

Gray jay

Solitary vireo

Nashville warbler

Cape May warbler
Yellow-rumped warbler

Blackburnian warbler

Ovenbird

Chipping sparrow

The pine community is easily recognized. Today, it is prevalent in the northern portion of the Superior National Forest, especially the Interior Zone of the BWCA, where logging has been minimal. During the early 1900's, many acres of pine stands were logged. Succession to the aspen community followed. One hundred years ago, pine forest covered approximately 7 million acres in Minnesota, Wisconsin, and Michigan, while today it covers about 1 million acres. Thus, this community is much less common than it was in presettlement times.

\section{MATURE DECIDUIOUS COMMUNITY}

The mature deciduous community includes a variety of tree species because it is difficult to separate different bird communities within the various deciduous communities. In the Superior National Forest, the following tree species have been grouped into the mature deciduous community: quaking aspen, bigtooth aspen, balsam poplar, paper birch, yellow birch, red maple, sugar maple, and red oak. The community structure is typically between 30 and 70 feet high. The canopy is dominated by any of the eight previously listed tree species. The subcanopy is typically well developed with sapling trees of balsam fir, black spruce, and berry-producing trees such as juneberry. The shrub layer is also well developed and consists of beaked hazel, juneberry, dogwood, mountain maple, and young saplings of the canopy. The herbaceous layer is well developed with a diversity of plant species including the large-leaf northern aster, wild sarsaparilla, and bracken fern.

Bird species associated with this community are typically found in the temperate deciduous forest biome and, thus, are common in the southern and eastern areas of the forest.

Primary breeding species are: 
Broad-winged hawk

Yellow-bellied sapsucker

Least flycatcher

Black-capped chickadee

Veery

Red-eyed vireo
Black-and-white warbler

Ovenbird

American redstart

Scarlet tanager

Rose-breasted grosbeak

Secondary breeding species include:

Ruffed grouse

Hairy woodpecker

Downy woodpecker

Eastern wood pewee

Hermit thrush
Philadelphia vireo (rare)

Black-throated green warbler

Canada warbler

Purple finch

White-throated sparrow

There are also species that are generally restricted to the southern part of the Superior National Forest. They are at the northern limits of their range and include the great crested flycatcher, white-breasted nuthatch, and wood thrush.

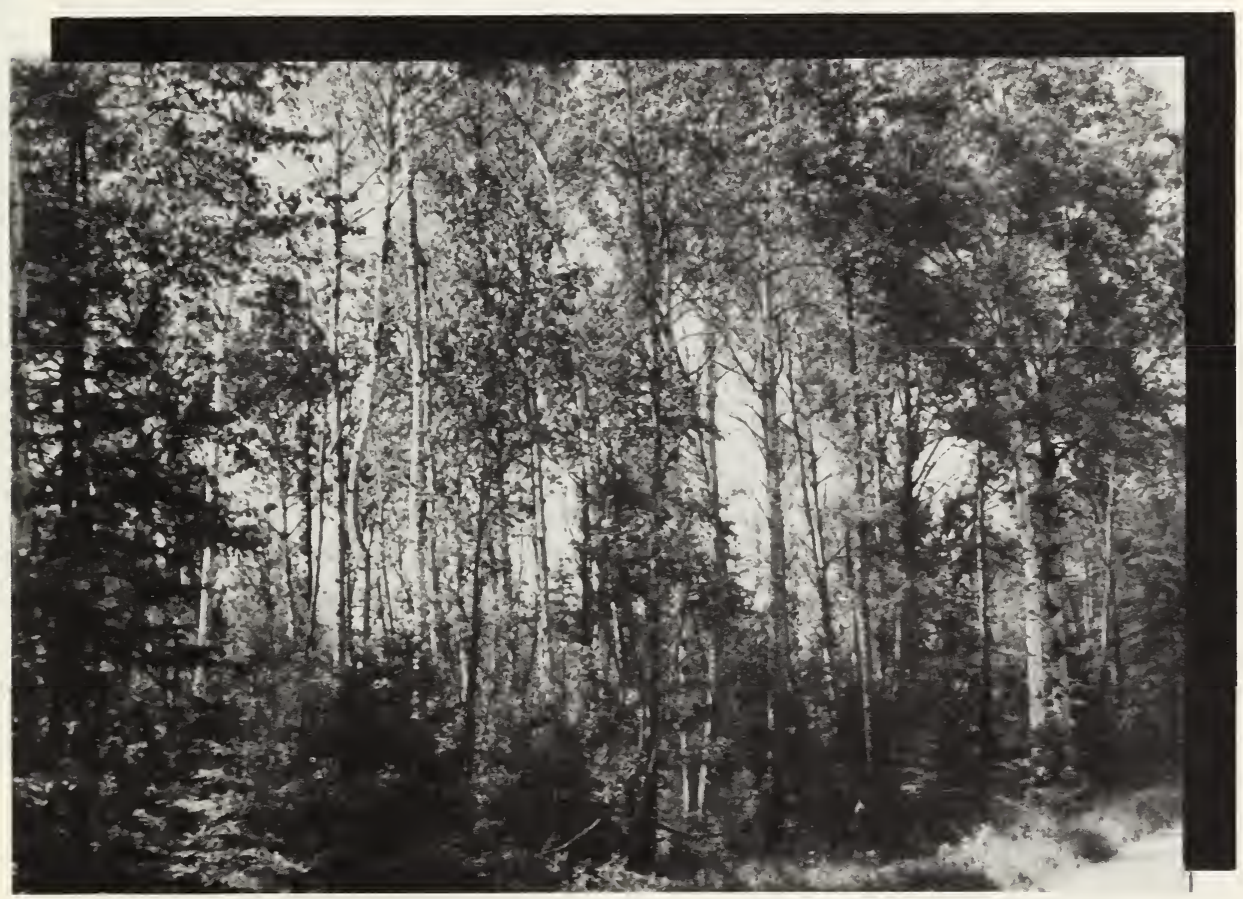

In general, most bird communities are similar for all the mature deciduous stands. However, the mature northern hardwood type (maple-basswoodyellow birch), which is considered to occur in response to the climate created by its proximity to Lake Superior, deserves special consideration. This com- 
munity occurs along the North Shore highland adjacent to Lake Superior and represents the climax phase of the eastern deciduous forest. The blackthroated blue warbler is a species unique to this specific community of the forest.

\section{BLACK SPRUCE-TAMARACK COMMUINITY}

One of the most unique bird communities in the Superior National Forest is found in the black spruce-tamarack community. This community, associated with the boreal ecosystem, is often in lowland areas and typically is dominated by black spruce or tamarack, with some balsam fir or jack pine. The subcanopy is usually poorly developed and consists of black spruce, balsam fir, and clumps of alder. The high shrub layer is also poorly developed and most often consists of willow and alder. The low shrub layer is variable and may often be quite substantial when ericaceous shrub species are present, especially Labrador tea. The herbaceous layer is dominated by mosses and is usually quite prominent.

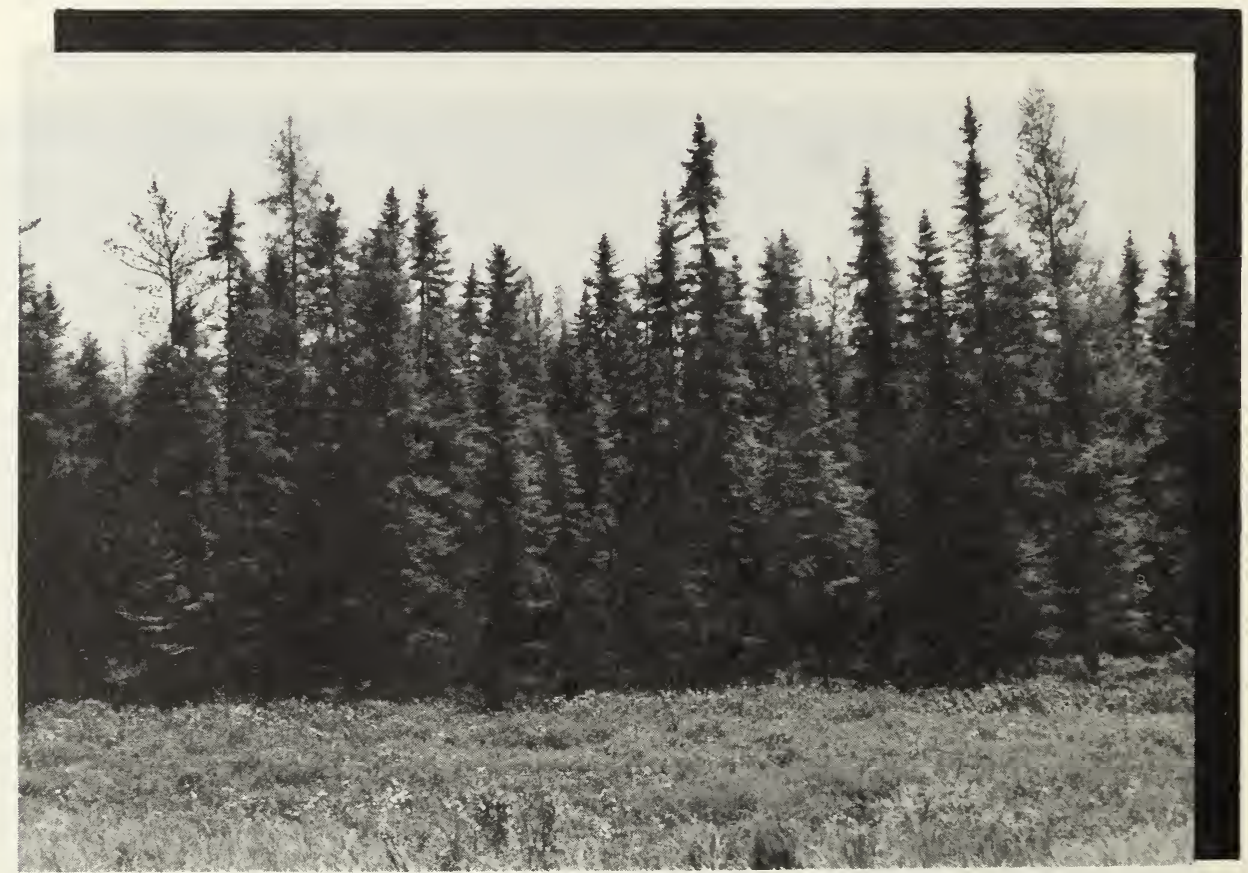

The bird species found within this community are generally among the most unique and indigenous to northeastern Minnesota. That is, their breeding distributions within the United States are restricted to areas where this community occurs such as in isolated parts of northern Wisconsin, the Upper Peninsula of Michigan, New England, and most abundantly in Minnesota. This community is distributed throughout the Forest but is most abundant between Aurora and Isabella. 
Primary breeding species of this community are:

Yellow-bellied flycatcher

Hermit thrush

Swainson's thrush

Golden-crowned kinglet

Ruby-crowned kinglet

Secondary breeding species include:

Spruce grouse

Black-backed three-toed woodpecker

Olive-sided flycatcher

Gray jay

Boreal chickadee

Red-breasted nuthatch

Winter wren

Solitary vireo
Nashville warbler

Cape May warbler

Yellow-rumped warbler

Connecticut warbler
Tennessee warbler

Northern parula

Magnolia warbler

Blackburnian warbler

Bay-breasted warbler

Northern waterthrush

Evening grosbeak

Pine siskin

Dark-eyed junco

Chipping sparrow

This may be the best community in which to observe the northern threetoed woodpecker in Minnesota, especially in the winter.

\section{ERICACEOUS-MUSKEG BOG COMMUNITY}

Another distinctive northern boreal community is the ericaceous-muskeg bog community. It has few trees except for occasional black spruce and

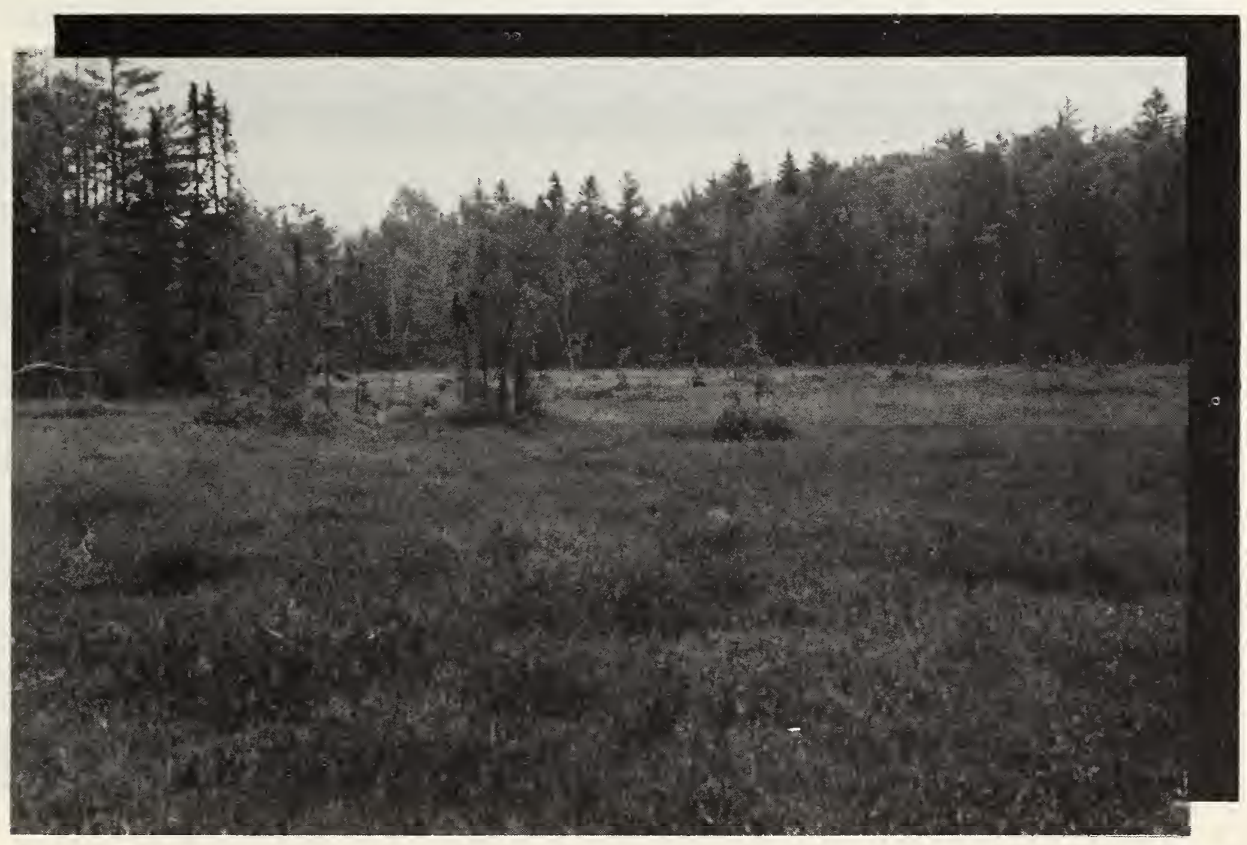


tamarack. Often, this community is difficult to distinguish from the sprucetamarack community if the tree layer becomes extensive. The subcanopy and high shrub layers are virtually non-existent except for occasional patches of alder, willow, birch, black spruce, or tamarack. Characteristic species of the low shrub layer - the most dominant layer, are the ericaceous-heath species such as Labrador tea, leather leaf, bog laurel, bog rosemary, and dwarf birch. Characteristic herbaceous species include blueberry, cranberry, and various mosses.

Primary breeding species of this community are:

Nashville warbler

Connecticut warbler

Lincoln's sparrow

Common yellowthroat

Swamp sparrow

Secondary breeding species dependent on the availability of at least a few scattered trees include:

Yellow-bellied flycatcher

Hermit thrush

Tree swallow

Tennessee warbler

Gray jay

Boreal chickadee

Palm warbler (rare)

Dark-eyed junco

This community is also used by the spruce grouse for breeding activities. If the tree layer is extensive, any of the species listed in the spruce-tamarack community could be found in this community.

\section{MIXED DECIDUOUS-CONIFEROUS COMMUNITY}

This community is very common in the forest. It is defined as an all-

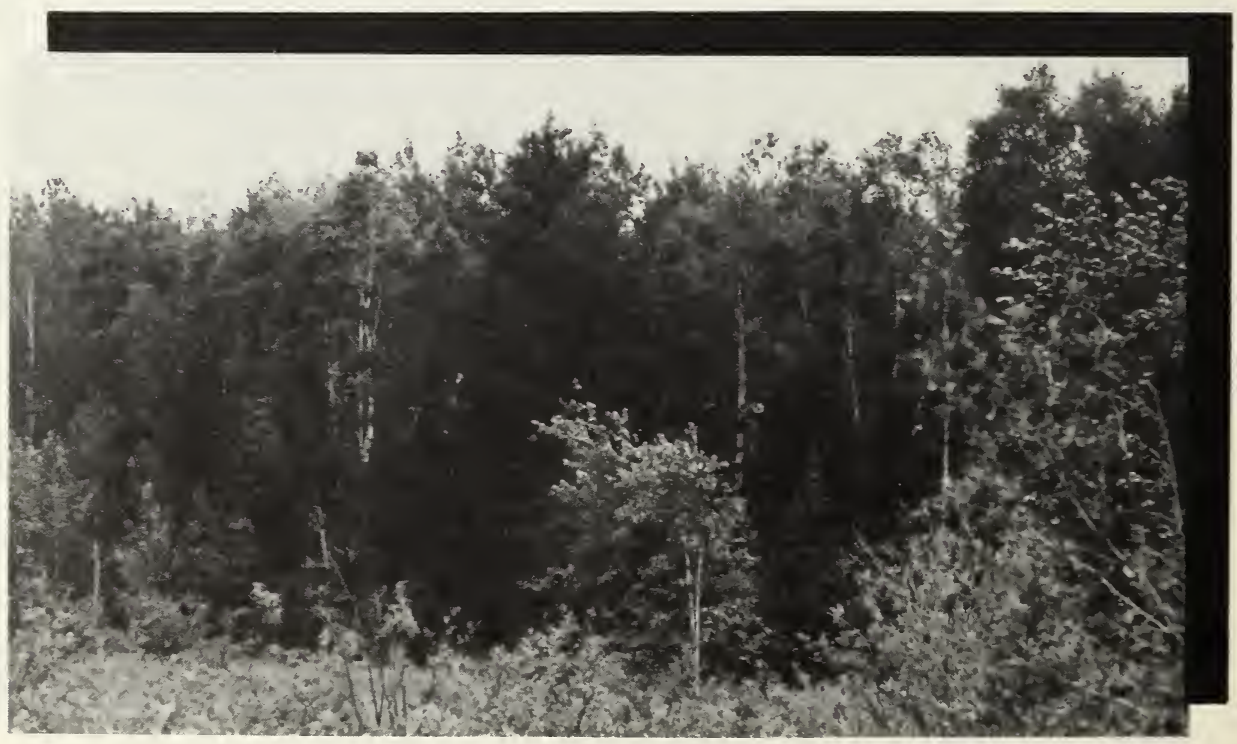


inclusive forest community and includes both mature deciduous and coniferous components. The canopy is the predominant vegetative strata and varies from moderate to highly dense. Tree species are highly variable. The subcanopy and shrub layers are normally well developed and consist of younger species of the forest canopy or hazel, juneberry, dogwood, and mountain maple. Low shrub layers are normally not well developed and herbaceous layers consist of large-leaf northern aster, wild sarsaparilla, and bunchberry.

The bird species found in this mixed community may include any of the species previously identified in the deciduous or coniferous communities. However, the following species are especially typical of this community:
Broad-winged hawk
Black-throated green warbler
Ruffed grouse
Black-capped chickadee
Ovenbird
Veery
Canada warbler
Black-and-white warbler
Purple finch
White-throated sparrow

This community is especially common in the southern part of the Forest where the balsam fir-birch community is prominent.

\section{OPEN DISTURBED COMMUNITY}

This community is usually created by forest fires and logging activity. The species associated with these areas are often similar, but depending on the type of disturbance and the number of trees remaining in the area, they can also be quite different. For example, if a logged area has been completely clearcut and no trees remain, there is little suitable habitat for birds dependent

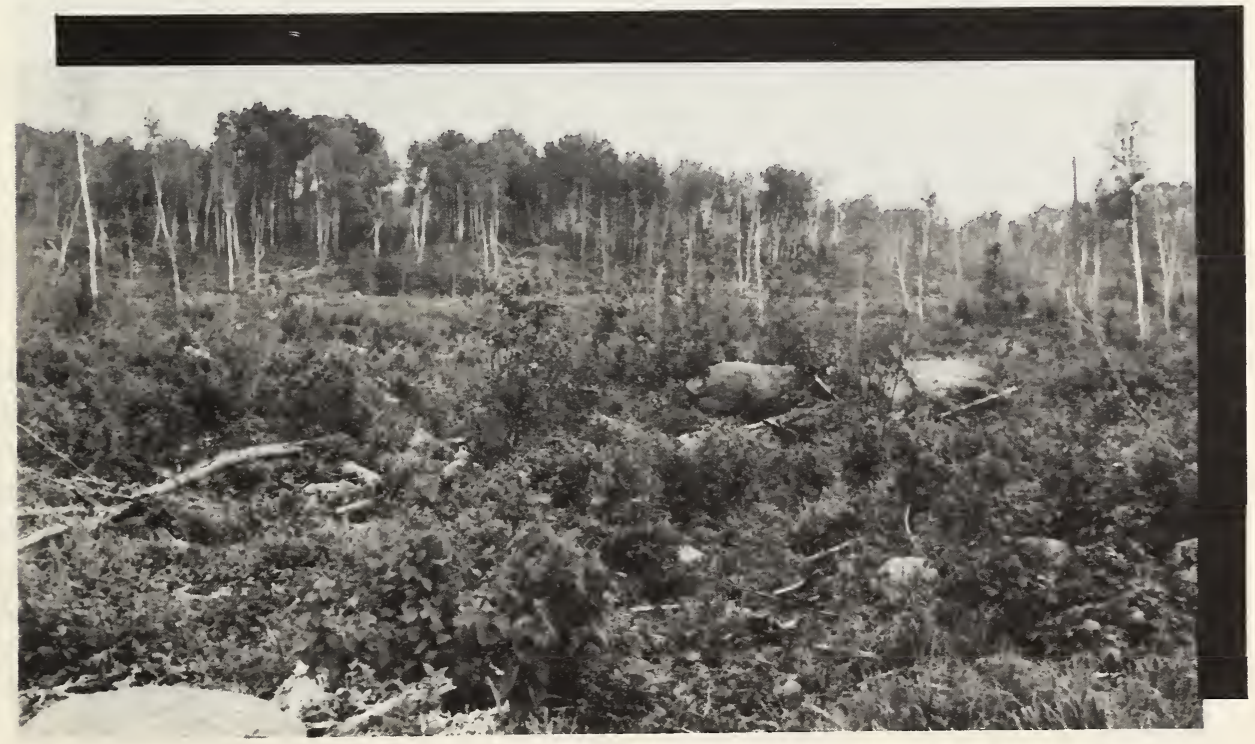


on snags such as cavity nesting woodpeckers or wrens. Conversely, if an area has been selectively cut, a logged area and a burned area may offer similar habitat to birds. No distinction has been made between deciduous or coniferous trees present in this community. Rather, the presence or absence of trees in a specific area determines if some of the species mentioned here will occur.

The main vegetative feature of this community is the dominant shrub layer or patches of herbaceous plants, such as raspberry. Typical shrub species include aspen, hazel, birch, dogwood, pincherry - especially in burn areas, juneberry, jack pine, or other sapling trees that will dominate later successional stages. Typical herbaceous species that invade barren ground and waste areas are fireweed, geranium, bristly sarsaparilla, bindweed, and many composites including goldenrod and asters.

The bird species in these areas are generally distinctive from other communities, although the red-eyed vireo, least flycatcher, and veery are more typical of later successional stages.

Primary breeding species of this community are:

Red-tailed hawk

American kestrel

Common flicker

Eastern kingbird

Tree swallow

House wren
Brown thrasher

American robin

Chestnut-sided warbler

Mourning warbler

White-throated sparrow

Song sparrow

Secondary breeding species include:

Ruffed grouse

Killdeer (early stages only)

Black-backed three-toed woodpecker

Red-headed woodpecker (west only)

Hairy woodpecker

Downy woodpecker

Olive-sided flycatcher

Blue jay
Gray catbird

Hermit thrush

Eastern bluebird (rare)

Golden-winged warbler (south only)

Common yellowthroat

Indigo bunting

American goldfinch

Dark-eyed junco

The most important difference between the burned and logged areas is the presence of trees. Trees provide nesting sites (holes), resting sites, feeding perches for such birds as kestrel and red-tailed hawk, and song posts for passerines. If clear-cut logged areas are small, the trees on the perimeter can be used for these purposes. In addition, in many disturbed areas the first successional stages are grassland communities where the savannah sparrow, grasshopper sparrow, LeConte's sparrow, vesper sparrow, and clay-colored sparrow are found. With settlement of northern Minnesota, these species are probably more common in the Forest than they were prior to settlement of this area. 


\section{YOUING DECIDUOUS COMMUNITY}

The young deciduous community is an intermediate stage between the disturbed open and the mature deciduous communities. Precise separation between the three communities is difficult because they gradually change from one to another. The dominant vegetative strata is the subcanopy consisting largely of pole-sized apsen or birch. The age of this community is approximately 10 to 30 years, although a better measure is the vertical tree height of about 15 to 30 feet. A very dense layer is present and consists of birch, hazel, dogwood, mountain maple, and juneberry. The herbaceous species include those species of disturbed and mature deciduous communities.

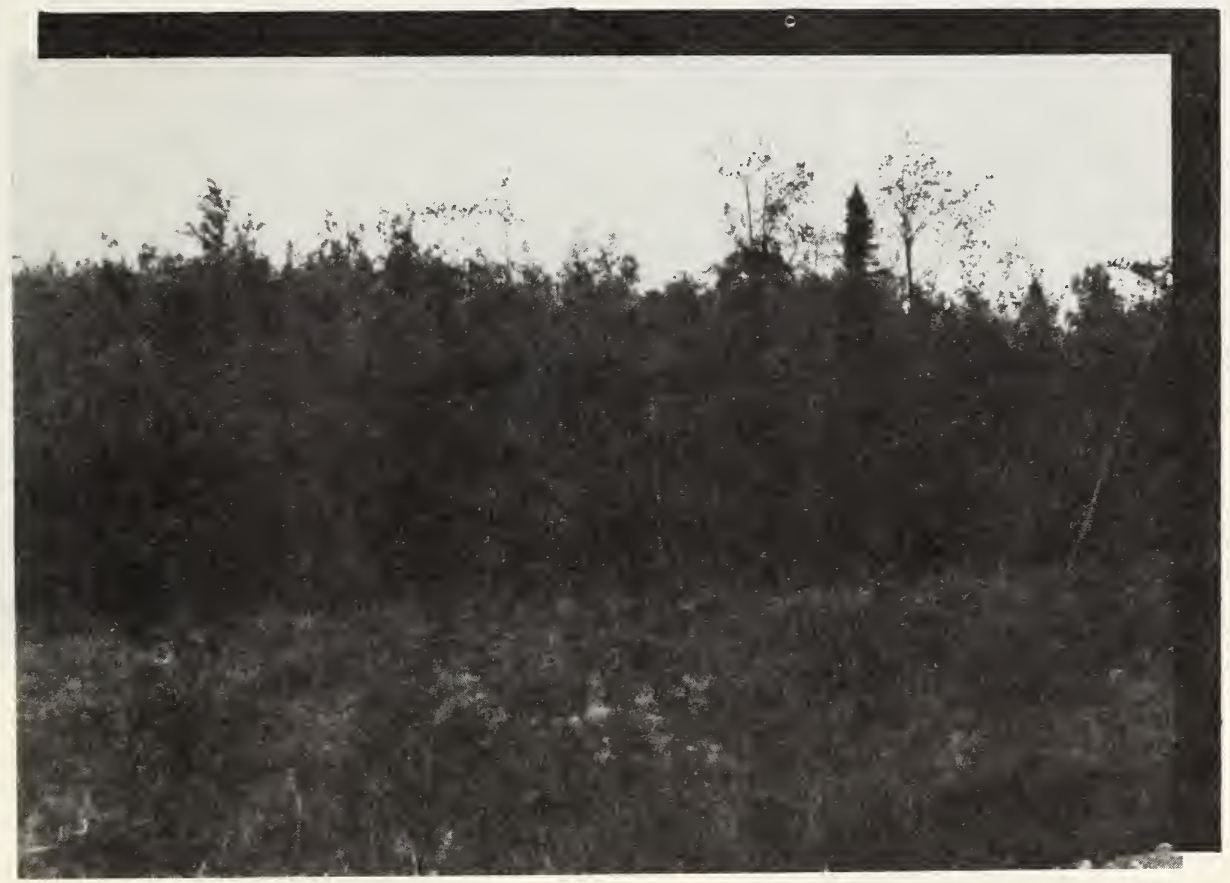

It is difficult to define the exact bird species that are exclusive to this community. Most often, the species are those that are more representative and have higher population densities in earlier successional stages, for example the mourning warbler, chestnut-sided warbler, and white-throated sparrow, or in later successional stages, like the least flycatcher, red-eyed vireo, ovenbird, and rose-breasted grosbeak. Some species may find this community most suitable or optimum for reproduction. Among these species are the ruffed grouse, downy woodpecker, blue jay and American redstart.

\section{YOUNG CONIFEROUS COMMUNITY}

The young coniferous community is a transition between young dis- 
turbed and mature coniferous communities. No distinction has been made between such tree communities as young red pine plantations, young black spruce stands, young tamarack stands, and young jack pine stands. The structural community is dominated by subcanopy-sized conifers, approximately 15 to 30 feet high. As with the young deciduous community, many of the birds associated with this community are in a transition. They are being

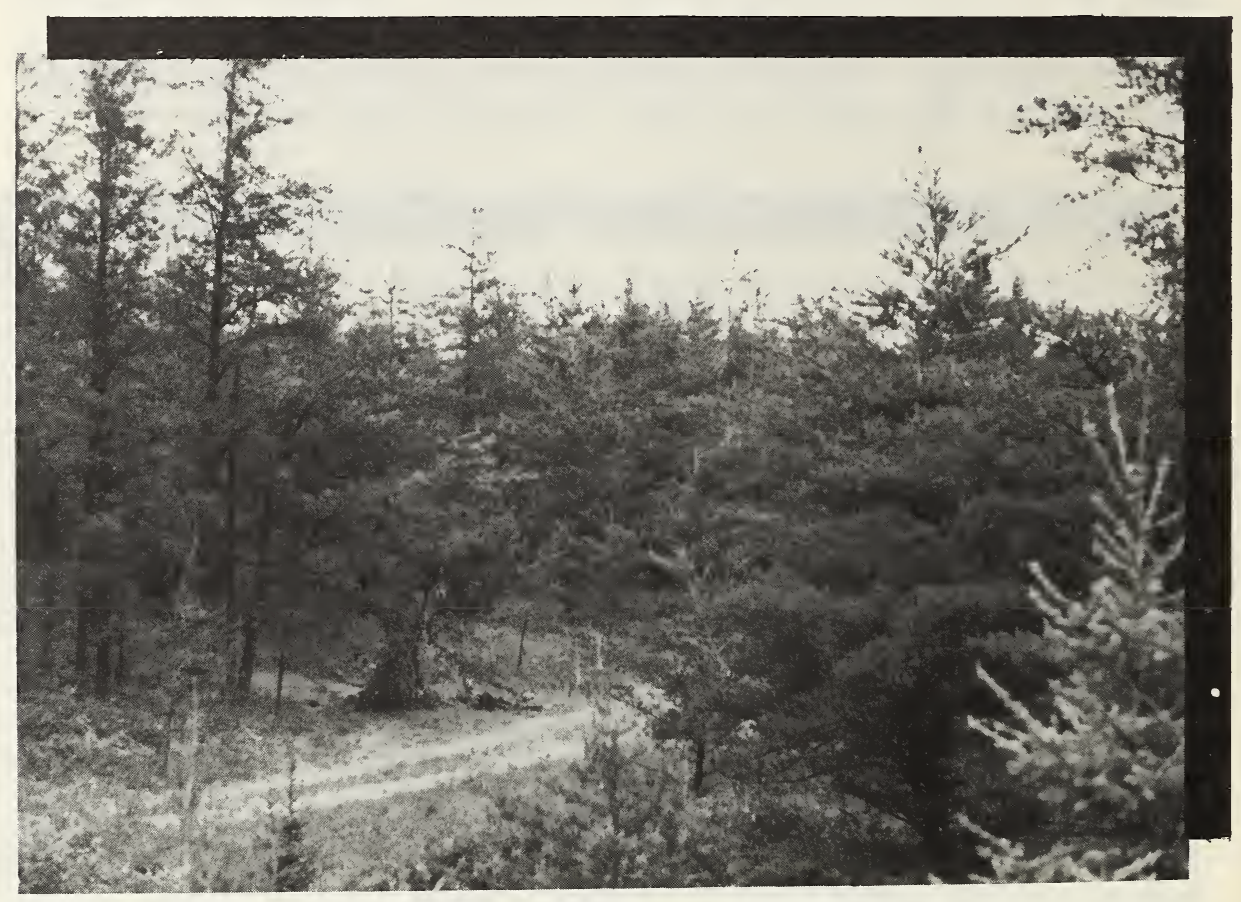

eliminated in the community as in the case of an early successional stage species like the chestnut-sided warbler, mourning warbler, and white-throated sparrow, or are colonizing the older community like the species typical of later successional stages including the Nashville warbler and yellow-rumped warbler. There are few species exclusive to the community, but the magnolia warbler is one typical species.

\section{WHITE CEDAR COMMUNITY}

This community is less extensive than the other communities and the bird species associated with it are not well known. The predominant canopy species is white cedar and is generally no more than 25 feet high. Understory vegetation varies considerably in density and species. Sphagnum moss, alder, willow, black spruce, tamarack, and ericaceous species may be present. Black ash, a lowland hardwood tree species, is not widespread in the Forest but it often occurs with white cedar. 


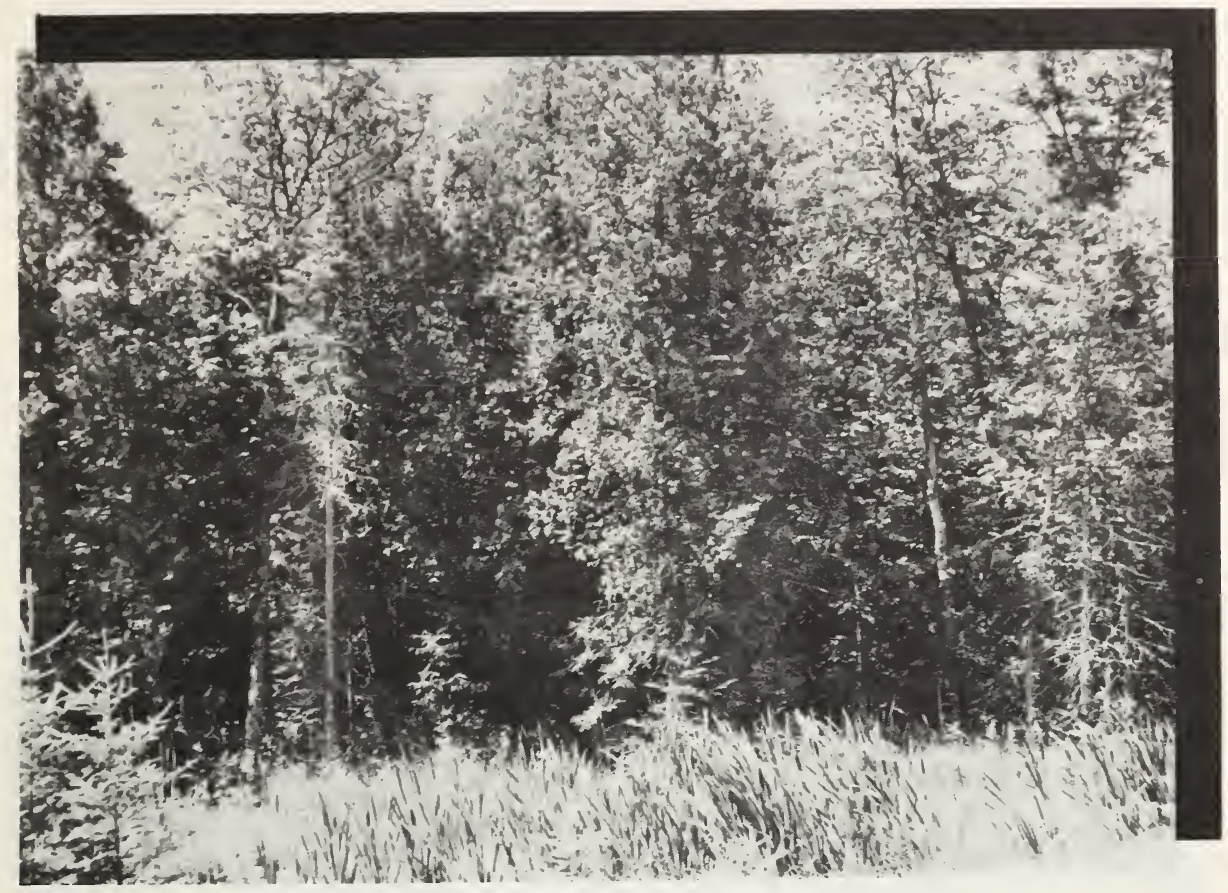

Almost any of the species found in both the spruce-tamarack or ericaceous muskeg-bog communities could be found in this community. Since there is very little known about the birds of this community, it is impossible to differentiate between primary and secondary breeding species. The following species, however, are distinctive species of the community:

$\begin{array}{ll}\text { Yellow-bellied flycatcher } & \text { Solitary vireo } \\ \text { Gray jay } & \text { Nashville warbler } \\ \text { Boreal chickadee } & \text { Magnolia warbler } \\ \text { Winter wren } & \text { Yellow-rumped warbler } \\ \text { Swainson's thrush } & \text { Northern waterthrush } \\ \text { Ruby-crowned kinglet } & \text { (water edges) } \\ \text { Golden-crowned kinglet } & \text { Canada warbler }\end{array}$

\section{ALDER-WILLOW COMMUNITY}

This is a relatively simple structured community and is especially common in the forest east of Aurora. In this area, there are many northeast to southwest ridges resulting from the last glaciation and this community occurs in the low areas between the ridges. Generally, no canopy or subcanopy layers exist in this community, while there are a few scattered tamarack, black spruce, or white cedar. This community often forms the understory of other communities such as the black spruce-tamarack. The dominant shrub species and the dominant vegetative strata are alder and willow with occasional 
patches of hazel, red-osier dogwood, and berry producing shrubs. The low shrub and herbaceous layers are usually dense and composed of a variety of marsh plants such as grasses, sedges, rushes, cattails, or ericaceous species.

Few bird species are exclusive to this community, as most are associated with other communities. However, bird species diversity and density have been found to be very high.

Primary breeding species include the following:

Alder flycatcher

Gray catbird

Yellow warbler

Chestnut-sided warbler

Mourning warbler
Common yellowthroat

American goldfinch

Swamp sparrow

Song sparrow

Secondary breeding species of this community include:

Common snipe American woodcock

Black-billed cuckoo

Downy woodpecker

Ruby-throated hummingbird

Eastern kingbird

American robin

Philadelphia vireo (rare)
Red-eyed vireo

Golden-winged warbler (south SNF only)

Wilson's warbler (very rare)

American redstart

Red-winged blackbird

Purple finch

White-throated sparrow

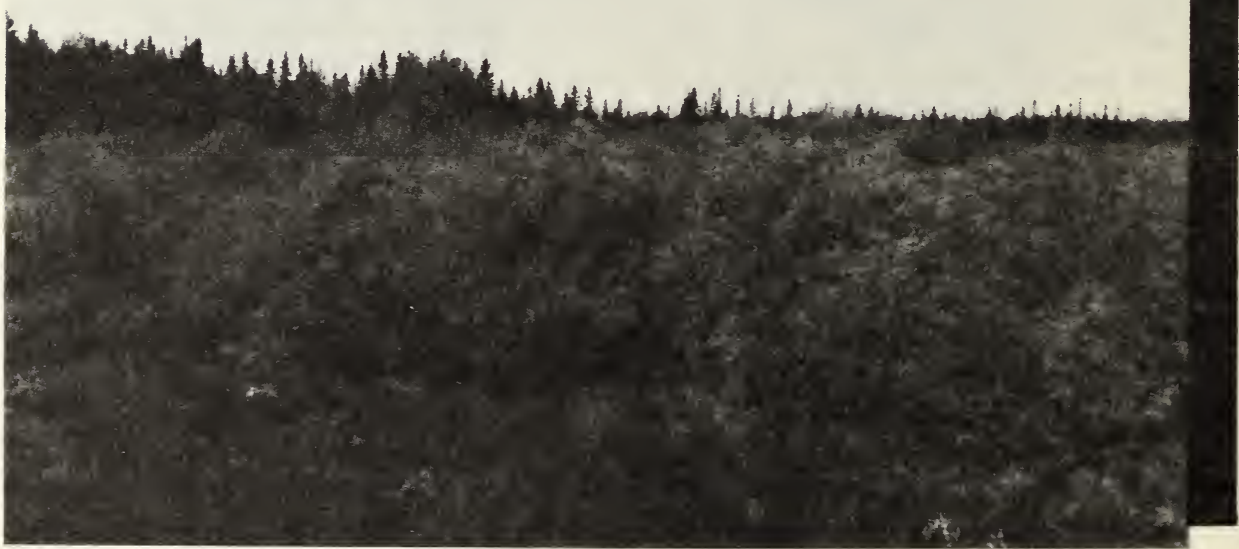




\section{CATTAIL-SEDGE MARSH COMMUNITY}

This community is generally well known because it is common throughout much of the United States. There is no canopy, subcanopy, or shrub layer except for occasional patches of alder or willow. The predominant species of the community are either the cattail, sedge, or various grasses between 1 and 4 feet high. In the northeastern part of the Forest this habitat is

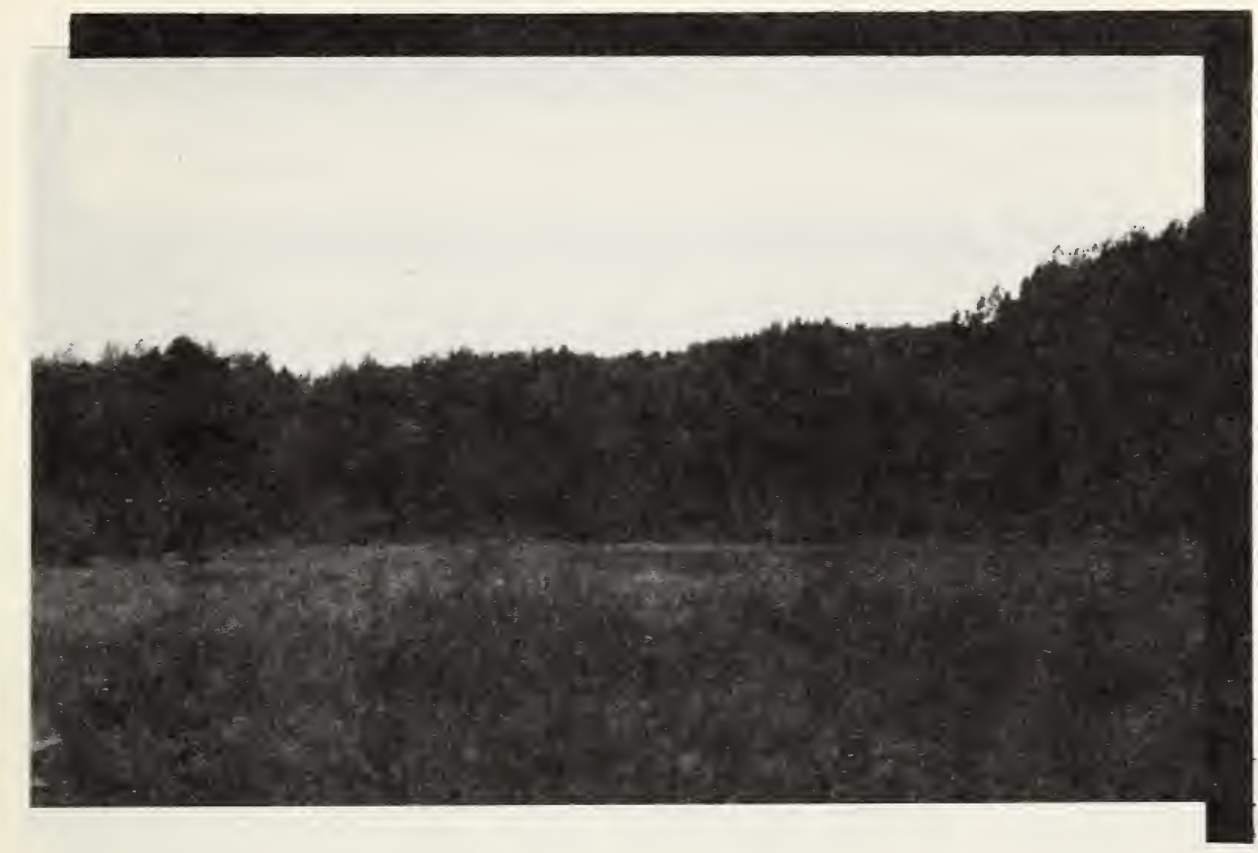

rare. Herbaceous plants are typically aquatic because the community is usually under water.

Primary breeding bird species of this community include:

Common yellowthroat

Red-winged blackbird

Common grackle

Swamp sparrow

Secondary breeding bird species include:

American bittern

Marsh hawk

Sora
Common snipe

Short-billed marsh wren

Yellow-headed blackbird (rare)

\section{WOODLAND POND COMMUNITY}

This community is very abundant in the once glaciated Superior National Forest. Often created by the beaver's impounding of small rivers and creeks, the typical setting is a small area of shallow water surrounded by a variety of plants such as alder, willow, cattail, or ericaceous species. This in turn grades 
into larger tree species such as aspen, birch, spruce, tamarack, or an occasional pine.

The primary breeding species of this community include:

$\begin{array}{ll}\text { Mallard } & \text { Red-winged blackbird } \\ \text { Tree swallow } & \text { Common grackle } \\ \text { Eastern kingbird } & \text { Swamp sparrow } \\ \text { Common yellowthroat } & \text { Song sparrow }\end{array}$

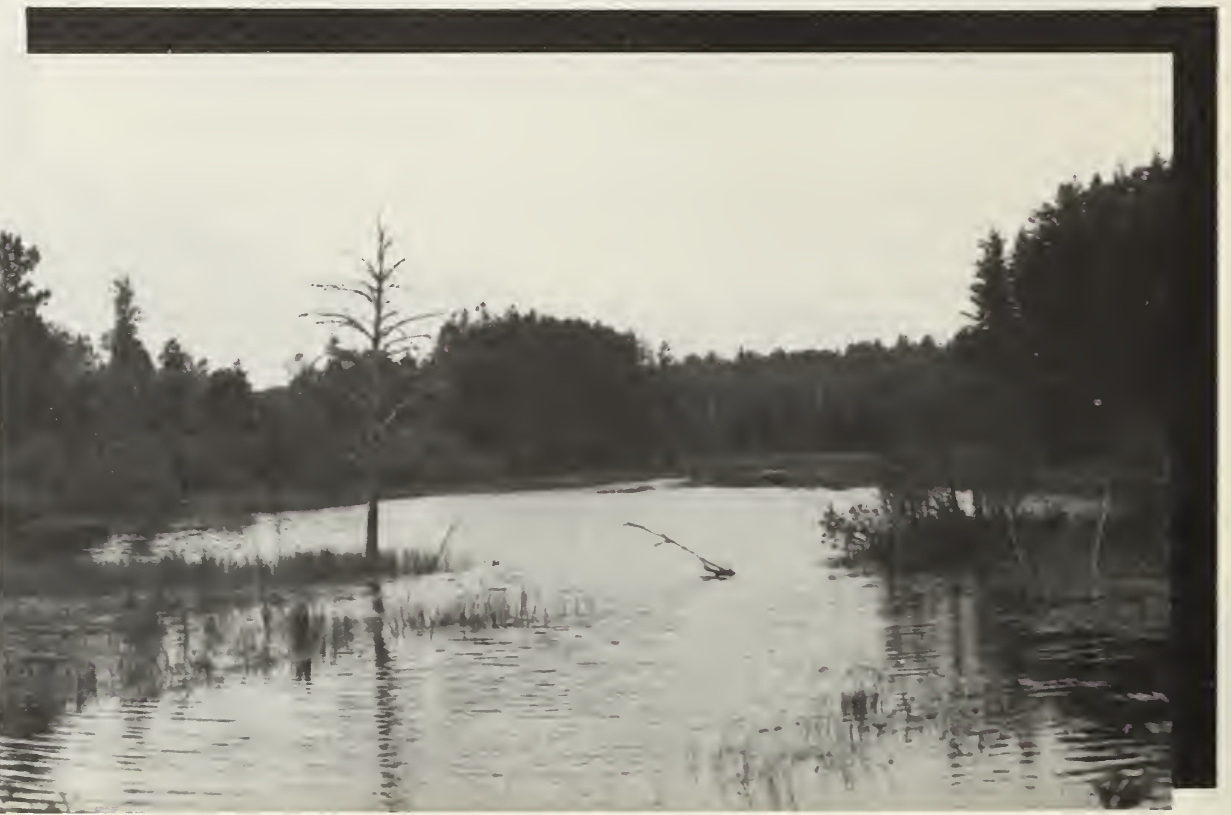

The secondary breeding species of this community include:

Common loon

Pied-billed grebe

Great blue heron

American bittern

Black duck

Blue-winged teal
Wood duck

Ring-necked duck

Common goldeneye

Hooded merganser

Spotted sandpiper

Belted kingfisher

During the migration season almost any of the waterbird species occurring in northeastern Minnesota could potentially be found in this community type. Broadwinged hawks may nest near the woodland pond in an adjacent deciduous community.

\section{LARGE LAKE COMMUNITY}

This community is one of the main attractions to recreationists. Except for its size and water qualities, there is no clear relationship between this 
community and the previously mentioned woodland pond community. The former community is generally made up of slow-moving, stagnant water, whereas the large lake community is subject to the normal influences of larger bodies of water such as currents and wave action. With the many lakes found in the Superior National Forest, this community is quite abundant and comprises much acreage.

The primary species breeding in this community include:

Common loon

Great blue heron

Common merganser

Bald eagle
Osprey

Spotted sandpiper

Herring gull

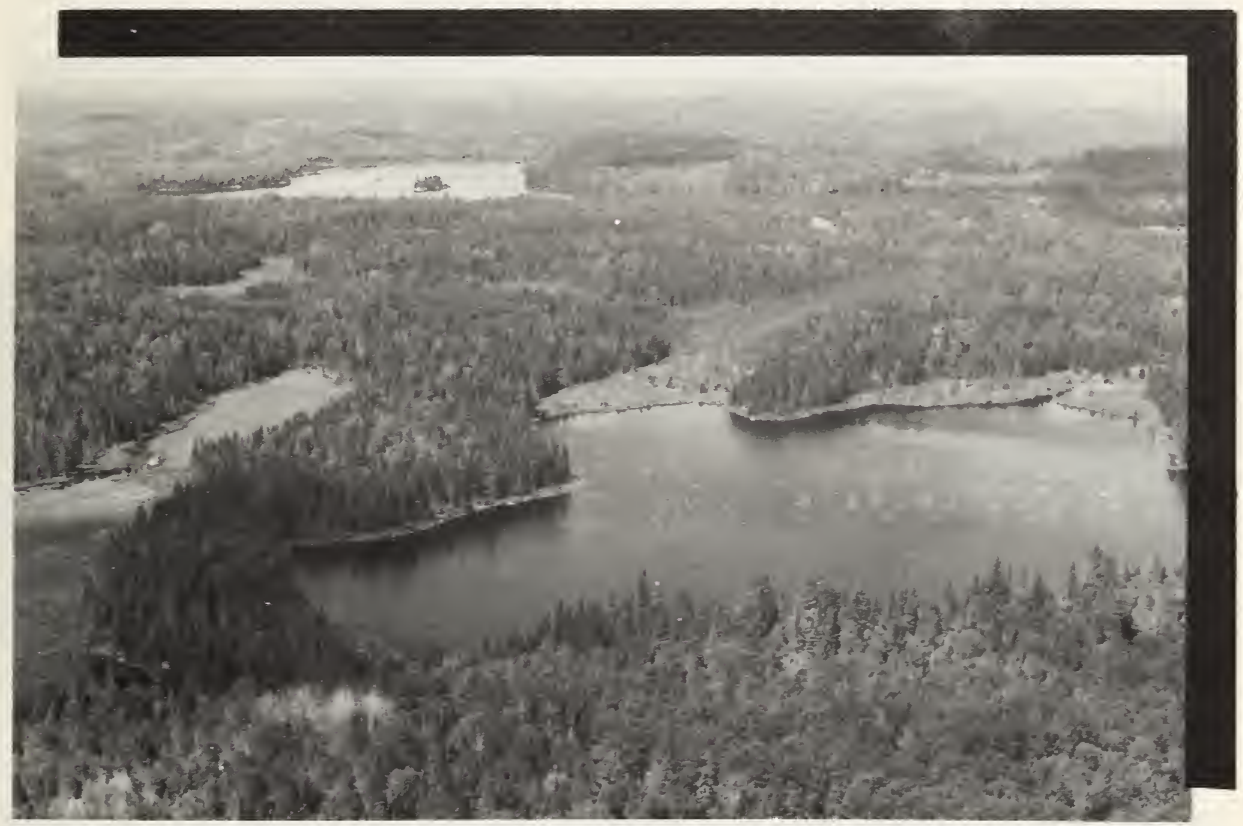

The secondary breeding species include:

Mallard

Black duck

Ring-necked duck
Common goldeneye Hooded merganser

Red-breasted merganser

As with the small woodland pond community, almost any of the waterbirds occurring in northeastern Minnesota during the migration season could be found inhabiting this community.

\section{URBAN-FARM COMMUNITY}

This community is closely associated with human activity. The characteristic components include houses, buildings, bridges, nest boxes, feeders, fences, telephone lines, roads, hayfields, shade trees such as elm and maple, 
and grassy areas.

The primary breeding species with their specific structural features of association shown in parenthesis include:

Killdeer (bare ground)

Common nighthawk

(flat roof tops)

Common flicker

Eastern kingbird

Tree swallow (nest boxes)

Barn swallow (buildings)

Cliff swallow (buildings)

Purple martin (nest houses)

Blue jay

Common crow

Black-capped chickadee

House wren (nest houses)

American robin (lawns, nest sites)
Warbling vireo (shade trees)

Starling (houses, buildings, feeders)

Yellow warbler

House sparrow (houses, buildings, feeder)

Northern oriole (shade trees)

Brewer's blackbird (roadsides)

Common grackle

American goldfinch

Savannah sparrow (fields)

Song sparrow

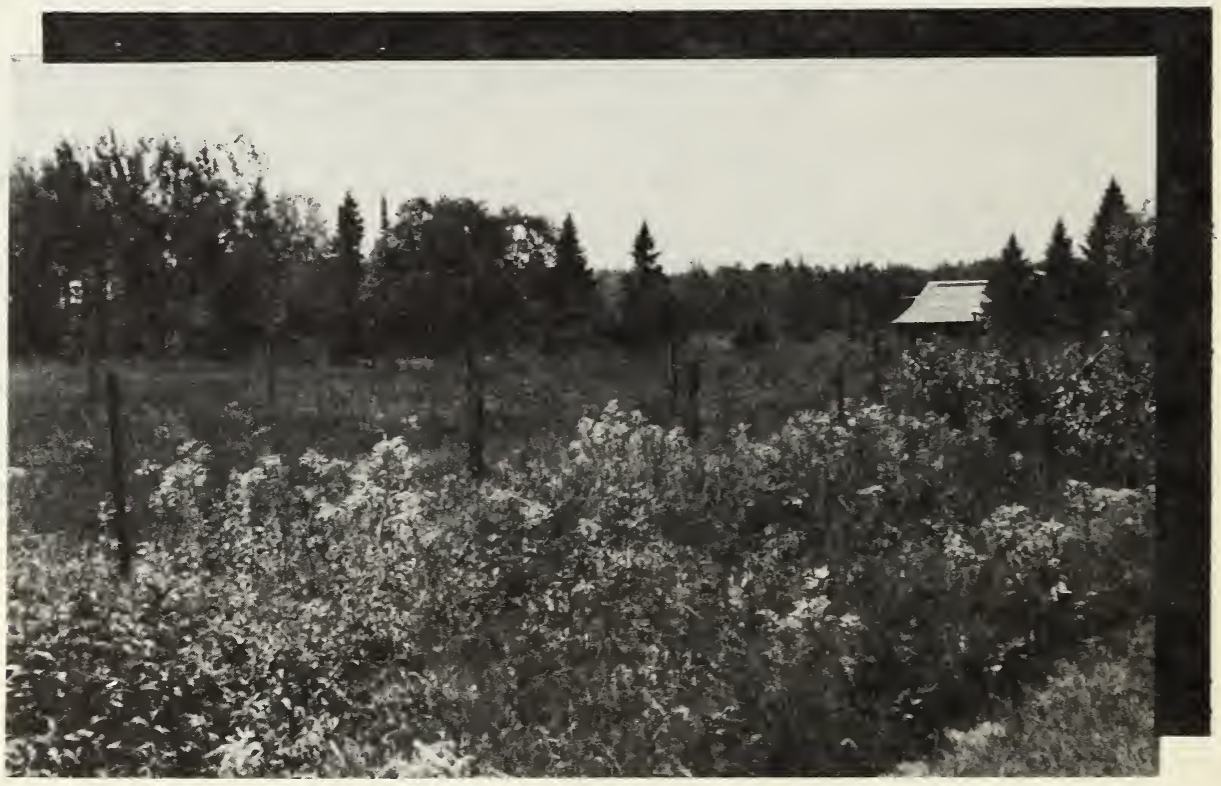

Secondary breeding species of the community are:

American kestrel

Rock dove (buildings)

Mourning dove

Chimney swift (buildings)

Eastern phoebe (bridges)
Eastern bluebird (nest boxes)

Bobolink (fields)

Eastern meadowlark (fields)

Brown-headed cowbird

LeConte's sparrow (wet fields) 
Rough-winged swallow

(bridges)

Catbird

Brown thrasher
Vesper sparrow (fields)

Chipping sparrow (evergreens)

Clay-colored sparrow (brushy fields)

These species are found in similar situations throughout the United States. Thus, their uniqueness or specificity to the forest is minimal.

\section{MISCELLANEOUS}

Some species have specific needs beyond vegetative structure, while others are very adaptable. This makes it difficult to pinpoint their habitat requirements. Species that have needs beyond vegetative structure include the pileated woodpecker. This bird generally occurs wherever there are very large trees with an available food supply. The cedar waxwing is almost always found close to an abundant food supply such as berry trees or an emerging insect hatch on a river or small pond. The belted kingfisher and bank swallow are found near exposed banks and use this for nest sites. Parula warblers are found near Usnea moss or "old man's beard", as this is a requirement for nest building. Common nighthawks nest on rock surfaces throughout the forest including the tops of flat pebble roofs on buildings. There is virtually no habitat data on owls of the Superior National Forest. Presumably, the great horned owl, barred owl, and saw-whet owl are all associated with woodlands.

Other species that are difficult to place into a specific community because they range over wide areas include the goshawk, merlin, common raven, and common crow.

\section{CHAPTER 5: BIRD FINDING}

\section{CASUIAL BIRD WATCHING}

Bird watching in a dense forest environment is a challenging task. The casual observer is most likely to see only the large and conspicuous species that are visible along bodies of water, roads, or other openings. However, most of the species in the Superior National Forest are songbirds that are both obscured by the vegetation or absent during the seasons when the leaves are off the trees. Even during migration, when concentrations or waves of birds are seen elsewhere in more open areas, large numbers of birds are difficult to find in the forest.

During migration and in the winter, the north shore of Lake Superior is the best place for finding flocks of birds in the national forest. The lake and open shoreline provide habitat for waterbirds, shorebirds, and tundra species like larks and longspurs. Lake Superior, however, is a very infertile body of water and most ducks that come to rest there do so for only a short period of time. The exception is during the late April spawning run of smelt when many diving ducks congregate near the mouths of North Shore streams. Flocks of 
oldsquaw, goldeneye, and scoters can be seen in late fall and winter, particularly in the Hovland-Grand Marais area. Groups of migrating land birds can also be found along the North Shore more easily than elsewhere in the national forest. Land birds, grounded by weather during migration, are concentrated along the shore, especially in the fall. They can be watched in the many public parks and waysides. Fall is also a good time to look for vagrants who are out of their normal migration path and are stopped by the broad expanse of Lake Superior. Finches and other northern invaders migrate throughout the early winter, and the abundant mountain ash berries and conifer seeds of the North Shore attract them. More information on specific places to watch birds on the North Shore can be obtained from K. R. Eckert's A Birder's Guide to Minnesota.

Inland, the chance of finding large groups of birds in either winter or the migration season is more uncertain. If berries and cones are available, the invading northern finches will flock to them and then move on as the supply is exhausted. Ducks and other waterbirds use the inland lakes for resting and feeding but not in the numbers that are found in the Mississippi or prairie flyways. Most lakes are still frozen at the height of the spring duck migration. Waves of migrating passerines are not encountered as frequently as they are further south. Spring migration is very brief and most birds seen at this time are on breeding territories. In the fall, the birds gradually leave the national forest. Migrants from farther north usually pass overhead, making their first landfall to the south. The early cold fronts of August sometimes bring waves of warblers into the national forest, but by September only stragglers remain. If the weather forces migrants to be grounded, flocks of sparrows can be found later in the fall, particularly along gravel roadsides.

Summer is interesting for bird watching in the Superior National Forest. The variety of forest birds surpasses other wooded areas in Minnesota and some species are of special interest because of their rarity elsewhere in the United States. Unfortunately, bird watching during the summer is more difficult than at other seasons due to the thick vegetation, early hour of peak bird activity, confusing songs of many species, especially warblers, and the hordes of biting insects. In dense foliage, song often provides the only clue to a bird's presence and further identification is not necessary once the songs have been learned. Knowing what birds are present greatly enriches one's appreciation of the variety of life in the forest.

The following hints may aid the novice birder during the nesting season of June and July.

1. Identification by sound. This technique is more difficult to master than sight identification, but the use of recordings of bird songs is a great help as is a knowledgeable companion. During the breeding season, an observer might easily identify 10 to 20 species by just standing in one spot and listening, never seeing a bird. After very early July, the volume of bird song dies down rapidly although the birds are still present. Then, the sound of young birds, 
recently out of the nest and begging for food, is often the only indication of their presence.

2. Observe at the time of greatest bird activity. The first 2 to 3 hours after sunrise are when birds are most active and hence most conspicuous. This is distressingly early for most people, but the experience of hearing the dawn chorus by walking through the woods is well worth the effort.

3. Observe during good weather. Most birds are very inactive and quiet during rainy or windy weather.

4. "Swishing" to arouse the curiosity of the birds. It is often possible to attract nesting birds by standing or sitting still and making a squeaking sound by sucking in through closed lips or by making the sound reproduced by the word "swish" or "spsh" over and over again, emphatically. It helps if the "swishing" arouses a common bird like a white-throated or song sparrow who scolds the observer in its territory. This scolding also attracts many other birds who fly in from their adjacent territories to see what is going on. The "swishing" technique is most successful when the birds are feeding young.

\section{BIRDING AREAS}

Most bird watchers who make a special trip to the Superior National Forest are looking for particular species, usually those associated with boreal forest communities. The most sought after species for out-of-State birders include spruce grouse, three-toed woodpeckers, yellow-bellied flycatcher, boreal chickadee, Cape May and Connecticut warblers, winter finches, plus the northern owls - great gray, hawk, and boreal. It is not possible to send a person to a particular locality with absolute assurance of finding a sought-after species, because populations, song activity, land use, and other factors fluctuate a great deal. Many of the species listed above are present all year in coniferous habitats and this guide can be used at any season. Certain parts of the national forest have a higher proportion of accessible boreal habitats than others and consequently are the best places to search for the uncommon or rare species associated with that habitat. Many other coniferous forest bird species will be found in these areas as well as other more common species, due to the fact that no part of the national forest has extensive areas of uniform habitat.

The birding guide that follows gives areas and particular stands with mileages on National Forest Service roads.

The maintenance of logging roads is always uncertain so driving should be cautious; many of the roads may not be plowed in the winter. The guide must be used in conjunction with large scale national forest maps that can be purchased for 50 cents per sheet from the district ranger stations or the forest supervisor's headquarters in Duluth. There are two series of maps that show all the numbered Forest Service roads - one is a single sheet with a scale of $1 / 4$ inch to the mile covering the entire national forest; the other map has three sheets at a scale of $1 / 2$ inch to the mile. The birding areas are organized by 
Forest Service ranger districts. Other good boreal communities exist on the Superior National Forest, with those described being the most accessible.

\section{Gunflint Ranger District}

1. Brule River area - Located 16 to 21 miles north of Grand Marais on the Gunflint Trail (Cook County Highway 12). All of the triangle formed by the Gunflint Trail and Forest Service Roads 325, 315, and 152 should be birded. Watch for spruce grouse, boreal chickadee, Connecticut warbler, three-toed woodpeckers, and any northern owls or finches that might be present. Forest Service Roads 315 and 1378 north past Lima Mountain to the Gunflint Trail should be traveled as well with an eye out for boreal habitats. Some of the best boreal conifer stands include:

- Forest Service Road 325: On this road, $1 / 2$ mile west of its junction with the Gunflint Trail, an extensive black spruce area begins on the south side of the road and continues for approximately 3 miles to the west.

- Forest Service Road 144: On either side of this road, which goes eastward from the Gunflint Trail (18.8 miles from Grand Marais), is an upland black spruce area.

- Forest Service Road 152: Follow, from the junction of this road and the Gunflint Trail, north along the Gunflint Trail to a little north of its crossing at the North Brule River. Here is another area of upland black spruce.

2. Iron Lake Area - Located about 36 miles north of Grand Marais on the Gunflint Trail. The place to birdwatch is the west end of Cook Co. Hwy. 92 from its junction with the Gunflint Trail eastward for one mile to the lron Lake campground road; there is a black spruce stand on the north side of this county road.

3. Kekekabic Trail - Located about 47 miles north of Grand Marais on the Gunflint Trail. The trailhead is in the middle of a black spruce bog where there is a small parking lot. The trail itself goes west from the Gunflint Trail and offers a chance to birdwatch in the woods.

\section{Tofte Ranger District}

1. Sawbill Trail - This road, Cook County Highway 2, goes inland from the town of Tofte. The southern part of the Sawbill Trail has been extensively logged, but the northern half, from the junction with Forest Service Road 164 to Sawbill Lake, has a good proportion of mature boreal conifers.

2. Heartbreak Ridge - Located on Forest Service Road 166, going westward from the Sawbill Trail about 6 miles north of Tofte, the top of this hill is covered with a mature stand of northern hardwoods. It is the best spot in the State to consistently find black-throated blue warblers. The best birding area is from the junction with Forest Service Road 344 westward to almost the foot of the hill at Heartbreak Creek.

\section{Isabella Ranger District - North Part}

1. Wanlass Road - This road, Forest Service Road 172, goes eastward from the town of lsabella on State Highway 1. The entire road east to Hogback 
Lake is an interesting road for birding; a few good spots at the west end are given below.

- Forest Service Road 369: At the junction of this road and Forest Service Road 172 is an upland black spruce/jack pine stand; north to Kelly Landing on this road there is much mature forest, (pine, birch, and aspen) an unusual occurrence in an area that is as extensively logged as Isabella.

- Black spruce bog: On Forest Service Road 172, about 21/2 miles east of its junction with State Highway 1, is a bog that usually has a Connecticut warbler population.

2. Little Isabella River campground - Located about $4 \frac{1}{2}$ miles west of the Isabella store on State Highway 1. It has a mature stand of pine and provides an opportunity to walk around in the woods.

3. Flathorn Lake - Located on Forest Service Road 177, going north of State Highway 1 about 6 miles west of the Isabella store. The Isabella Environmental Learning Center maintains a hiking trail around the lake, offering good access through mixed woods to birdwatch for the more usual forest birds. The hiking trail can be reached from the Flathorn Lake picnic areas; the environmental learning center provides facilities for environmental education.

4. Tomahawk Trail - This main logging road, Forest Service Road 173, goes eastward from State Highway 1 about 6 miles north of the junction of State Highway 1 and Lake County Highway 2 (or about 20 miles from the Isabella store). Connecticut warblers and yellow-bellied flycatchers have been found in a spruce stand (partially logged in 1978) just east on Forest Service Road 173 from its junction with Highway 1. The rest of the Tomahawk Trail eastward to Isabella Lake passes through many lowland black spruce bogs interspersed with upland conifer and aspen stands and is a good place to look for the two species mentioned above and other boreal birds. The Tomahawk Trail, going west from State Highway 1 to Babbitt (Forest Service Road 424), also passes through some good black spruce bog country.

\section{Isabella Ranger District - South Part}

1. Jordan - The road to this railroad siding (Lake County Highway 204) is 1 mile north of the Langley River and swings eastward in a 5-mile loop from Lake County Highway 2. The southerly part of the Jordan Road, until it crosses the Cloquet River, goes through some spruce bogs and pine plantations. Lake County Highway 2 , for $3 \frac{1}{2}$ miles north of the junction with county highway 204, also goes through some black spruce bogs where spruce grouse are sometimes seen.

2. White Pine Picnic Area - Located on Lake County Highway 2 about 28 miles north of Two Harbors, this is an old growth stand of red and white pine.

3. Whyte Road - This road, Forest Service Road 104, goes east from Lake County Highway 2 about 1 mile north of the White Pine Picnic Area. It is a rough road that may be flooded after heavy rains and is not usually plowed, but it traverses one of the largest accessible spruce bogs in the national forest. 
About $4 \frac{1}{2}$ miles east of County Highway 2 the most extensive area of bog begins and continues eastward for about 5 miles; beyond that, the road traverses spruce-fir and aspen-birch forest to the Cloquet Lake Road (Forest Service Road 102). Both the great gray owl and spruce grouse are residents of the spruce bog country, but it takes a lot of hunting of their habitat to find one.

4. Greenwood Lake - At the western end of this lake and north for a couple of miles, Lake County Highway 2 traverses good black spruce bog habitat that alternates with more deciduous uplands. Spruce grouse should be looked for here.

\section{Aurora Ranger District}

1. Langley River - Located on Lake County Highway 2 about 21 miles north of Two Harbors, this spruce-fir forest suffered a spruce budworm outbreak in 1974 killing the firs. It is the most southerly area where boreal species like boreal chickadee, gray jay and the more usual warblers associated with conifers can be found with some regularity. Black-backed three-toed woodpeckers have also been seen there recently.

2. Fairbanks - West of this town on St. Louis County Highway 16, the road goes through a number of black spruce bogs in a 3 mile stretch that begins just west of the Whiteface River crossing. The boreal chickadee, gray jay, and black-backed three-toed woodpecker can be found here.

3. Forest Service Road 130 - Located about $11^{1 / 2}$ miles west of Fairbanks, it travels north from St. Louis County Highway 16 just west of the crossing of Mud Hen Creek. It is a quiet road for birdwatching. The best spots are the cedar swamp at the junction of Forest Service Road 1822 (about 4 miles north of county highway 16), the jack pine stand (singing Connecticut warbler) at the junction of the road to the Norway Point Picnic Area, and the picnic area itself. Further north, just east of the junction of Forest Service Road 130 and St. Louis County Highway 569, is an extensive black spruce bog on the north side of the county highway. This bog can be seen from the road but is difficult to penetrate; Connecticut warblers and boreal chickadees are found here.

\section{Kawishiwi and LaCroix Ranger Districts}

1. Echo Trail - This road, St. Louis County Highway 116, is one of the major roads within the national forest. It goes north around the east end of Shagawa Lake and connects Ely with the next town of Buyck through 50 miles of virtually uninhabited forest. The stretch of road that goes through the best boreal habitat is the east-west segment of the Echo Trail from Ed Shave Lake west to the Little Indian Sioux River. A large natural burn occurred in the Meander Lake area in 1971 (about 30 miles up the Trail from Ely); it has been a good place for black-backed three-toed woodpeckers. West of the burn the forest is mostly cutover or of mixed deciduous.

2. East End of Fernberg Road - This major road penetrates the forest east of Ely and is wide and paved for most of its length. It travels mostly through second-growth deciduous woods - not very special for birdwatch- 
ing. However, at its eastern end Forest Service Roads 1544 and 439 are worth exploring since they access some coniferous habitats.

\section{CHAPTER 6: ANNOTATED LIST}

The species on this annotated list are described first by the frequency of occurrence over a span of several decades and second by the type of occurrence within a single year. Several other kinds of information are included under the seasonal categories: 1) abundance rates for summer residents and winter visitors, 2) breeding habitat preferences, and 3) general migration times. The definitions and assumptions underlying the terms used are discussed below.

\section{FREQUENCY OF OCCURRENCE}

Regular - Occurs in the national forest every year during one or more seasons.

Occasional - Does not occur every year, but because of the proximity of its regular range in Minnesota it can be expected to wander into the national forest at frequent intervals.

Accidental - One to four records have been made in the last 20 years of these species that are not on the regular Minnesota list; or, these species are expected to occur again only very infrequently. Substantiating data on these records can be obtained from Minnesota Birds or issues of The Loon.

Extinct or Extirpated - Formerly occurred and is either no longer in existence anywhere (extinct) or has a population elsewhere (extirpated).

\section{SEASONAL STATUS}

Permanent Resident - A population that is primarily sedentary, remaining in the same area throughout the year.

Summer Resident - Occurs during the summer and nests. There are only a few summer observations for some species so their actual breeding needs confirmation. Record keeping has not been extensive enough to document nesting for all national forest species listed as resident, but extensive summer observations plus known range boundaries make the assumption of breeding realistic.

Summer Visitor - Stragglers into the national forest during the summer and not suspected as nesting.

Winter Visitor - Regular movement into the national forest during the winter from a breeding area farther north or west.

Migration - The normal times for passage through or into the national forest 
of both visitors and residents are given in 10 day intervals (early, mid, late) within the month. Out of necessity, much of the information was extrapolated from Minnesota Birds and field experience in the Duluth area.

\section{ABUINDANCE}

The abundance terms are used only for residents or visitors and are not given for migration, because during that season populations are weather dependent and very variable. The terms apply to the Superior National Forest as a whole and only to the forested environment. Therefore, populations that are local or found only in fields and towns are so described.

Abundant - Seen daily; 30 to 100 counted on a breeding bird survey* route.

Common - Seen daily; 10 to 29 counted on a breeding bird survey route.

Fairly common - Seen almost daily; 2 to 9 counted on a breeding bird survey route.

Uncommon - Seen at least weekly; 0 to 1 counted on a breeding bird survey route.

Rare - Found a few times each season.

Very rare - Not encountered every year unless species' habitats or locales are sought out.

Relative abundance terms for the summer residents are based on a forestwide designation from the following data: 1) 12 years of field experience in the Superior National Forest by Green; 2) the U.S. Fish and Wildlife Cooperative Breeding Bird Surveys for Sawbill Landing (north of lsabella on the Tomahawk Trail), Lockport (inland from Tofte along Honeymoon, Sawbill, and Heartbreak Ridge Trails), and Hovland (Arrowhead Trail to Mineral Center); 3) plot censuses by Niemi in the Little Sioux burn (Echo Trail) and by Doran at the Minnamax Site (southeast of Babbitt); 4) 2 years of transect and plot censuses by Niemi and Pfannmuller in the State of Minnesota Copper-Nickel Study Area (between Hoyt Lakes and the South Kawishiwi River); and 5) some species, such as the woodcock, black duck, kestrel, are not easily observed during the breeding bird survey or the plot census. This may result from breeding activities occurring before or after the standard late May-early June songbird census or from lack of habitat along a particular census route. Consequently, observations by the forest wildlife biologist, over a 6-year period, are included in this listing and noted in parenthesis following the Abundance Classification in the Annotated List.

\footnotetext{
*A breeding bird survey is a 25 mile route along which a census is taken by recording birds heard and seen for 3 minutes at $1 / 2$ mile intervals (50 stops) early in the morning on 1 day in June; routes randomly chosen by the U.S. Fish and Wildlife Service which collects the data nationwide.
}

It is difficult to set up categories that describe abundance over the entire national forest. There are major physiographic and land use differences, such 
as the rocky, wilderness lakeland of BWCA and the glacially deposited landforms to the south that have been extensively logged. The abundance terms are based on integrating all these differences, using experience and the defined standards.

\section{STATUS SUIMMARY}

There are 265 species on the Superior National Forest that include:

Regular -220

Occasional -22

Accidental -21

Extinct -2

The species present during the breeding season are classified as 155 permanent and summer resident species and 14 visitors. Slightly more than half, or 84 , of the resident species are numerous or widely distributed enough to be located frequently or almost daily. These residents are further divided as abundant ( 8 species), common (13 species), fairly common (23 species), and uncommon (38 species). The rest of the residents are either very rare (32 species), rare ( 27 species), or local in towns and fields (12 species) for a total of 71 infrequent breeding species. A listing of all the breeding species by abundance category is found in Table 1 in the appendix.

\section{Family GAVIIDAE: Loons}

COMMON LOON (Gavia immer): Regular

Summer: fairly common resident; lakes

Migration: early April — summer - early December

RED-THROATED LOON (Gavia stellata); Occasional

Summer: one record from Lake Superior $(7 / 31 / 52)$

Migration: one May and one October record from Lake Superior

\section{Family PODICIPEDIDAE: Grebes}

RED-NECKED GREBE (Podiceps grisegena): Regular Summer: occasional visitor; lakes

Migration: mid-April through late May; late August through late November

Winter: occasional Lake Superior

HORNED GREBE (Podiceps auritus): Regular

Summer: occasional visitor; lakes 
Migration: mid-April through late May; mid-August through mid-November

Winter: occasional on Lake Superior

EARED GREBE (Podiceps nigricollis): Occasional

Migration: occasional on Lake Superior in May and September

WESTERN GREBE (Aechmophorus occidentalis): Occasional

Migration: occasional on Lake Superior in May

PIED-BILLED GREBE (Podilymbus podiceps): Regular

Summer: rare resident; marshy lakes

Migration: late March - summer - early December

\section{Family PELECANIDAE: Pelicans}

WHITE PELICAN (Pelecanus erythrorhynchos): Occasional

Summer: two June records on Lake Superior in 1973

Migration: occasional in May and September

\section{Family PHALACROCORACIDAE: Cormorants}

DOUBLE-CRESTED CORMORANT (Phalacrocorax auritus): Regular Summer: occasional visitor; lakes

Migration: mid-April through early June; mid-September through early November

\section{Family ARDEIDAE: Herons and Bitterns}

GREAT BLUE HERON (Ardea herodias): Regular

Summer: uncommon resident: rivers, lakes and beaver ponds

Migration: early April - summer - early November

NORTHERN GREEN HERON (Butorides striatus): Occasional

Summer: one record from Trout Lake, St. Louis County $(7 / 16 / 69)$

AMERICAN BITTERN (Botaurus lentiginosus): Regular

Summer: rare resident; marshes and swamps

Migration: mid-April — summer — late October

\section{Family ANATIDAE: Swans, Geese and Ducks}

MUTE SWAN (Cygnus olor): Accidental

Records: three birds at Grand Marais, January 27 through March 16, 1975

WHISTLING SWAN (Olor columbianus): Regular

Summer: occasional visitor; lakes

Migration: early April through late May; early October through late November 
CANADA GOOSE (Branta canadensis): Regular

Summer: occasional visitor; lakes

Migration: mid-March through early May; early September through early December

Winter: occasional at Grand Marais

BRANT (Branta bernicla): Accidental

Records: one bird at Grand Marais on October 4, 1974

SNOW GOOSE (Chen caerulescens): Regular

Migration: mid-March through late May; mid-September through mid-November

MALLARD (Anas platyrhynchos): Regular

Summer: uncommon resident; lakes (fairly common-beaver ponds)

Migration: late march - summer - mid-December

Winter: regular at Grand Marais; occasional elsewhere

BLACK DUCK (Anas rubripes): Regular

Summer: uncommon resident; lakes (fairly common-beaver ponds)

Migration: late March - summer - mid-December

Winter: regular at Grand Marais; occasional elsewhere

GADWALL (Anas strepera): Occasional

Migration: late March through mid-May; early October through mid-November

PINTAIL (Anas acuta): Regular

Migration: late March through mid-May; early September through late November

Winter: one at Grand Marais (2/12/69)

GREEN-WINGED TEAL (Anas crecca): Regular

Summer: occasional visitor; lakes

Migration: early April through late May; late August through mid-November

BLUE-WINGED TEAL (Anas discors): Regular

Summer: very rare resident; lakes

Migration: mid-April - summer - mid-October

AMERICAN WIGEON (Anas americana): Regular

Summer: very rare resident; lakes

Migration: late March - summer - mid-November

Winter: one record at Grand Marais (12/12/74-1/25/75)

NORTHERN SHOVELER (Anas clypeata): Regular

Summer: one record of adults and young at Devil's Track Lake, Cook County $(7 / 3 / 22)$

Migration: early April through mid-May; early September through mid-November 
WOOD DUCK (Aix sponsa): Regular

Summer: rare resident; lakes and rivers (uncommon-beaver ponds)

Migration: early April - summer - late October

REDHEAD (Aythya americana): Regular

Summer: one record of four birds in June in Cook County (7/25-26/22)

Migration: mid-April through late May; late September through late November

RING-NECKED DUCK (Aytha collaris): Regular

Summer: uncommon resident; lakes

Migration: early April - summer - early December

Winter: occasional in early winter

CANVASBACK (Aythya valisineria): Regular

Summer: occasional visitor; lakes

Migration: mid-April through late May; late September through late

November

GREATER SCAUP (Aythya marila): Regular

Migration: late March through early June; late September through late November

LESSER SCAUP (Aythya affinis): Regular

Summer: occasional visitor; lakes

Migration: late March through early June; mid-September through mid-December

Winter: occasional in early winter

COMMON GOLDENEYE (Bucephala clangula): Regular

Summer: rare resident; lakes

Migration: mid-March - summer - mid-December

Winter: common visitor on Lake Superior; occasional elsewhere

BARROW'S GOLDENEYE (Bucephala islandica): Accidental

Records: three winter records from Lake Superior in Cook County

$(11 / 30 / 28 ; 12 / 12 / 74 ; 1 / 25 / 75)$ and one spring record inland in Lake County (5/11/74, Nine Mile Lake)

BUFFLEHEAD (Bucephala albeola): Regular

Summer: one record in July in Cook County $(7 / 24 / 28)$

Migration: mid-March through late May; mid-September through mid-December

Winter: occasional on Lake Superior

OLDSQUAW (Clangula hyemalis): Regular

Migration: late October - winter - late May

Winter: common visitor on Lake Superior

HARLEQUIN DUCK (Histrionicus histrionicus): Occasional

Migration: late October - winter - mid-April 
Winter: rare visitor on Lake Superior

COMMON EIDER (Somateria mollissima): Accidental

Records: female at Grand Marais on November 7, 1953

KING EIDER (Somateria spectabilis): Accidental

Records: female at Grand Marais on December 12, 1974

WHITE-WINGED SCOTER (Melanitta deglandi): Regular

Migration: mid-April through early June; mid-October through early December

Winter: occasional on Lake Superior

SURF SCOTER (Melanitta perspicillata): Regular

Migration: late April through early June; early October through mid-December

BLACK SCOTER (Melanitta nigra): Regular

Migration: late April through early June; early October through late November

Winter: one record at Grand Marais (1/1/72)

RUDDY DUCK (Oxyura jamaicensis): Occasional

Summer: occasional visitor; lakes

Migration: mid-April through late May; early September through late November

HOODED MERGANSER (Lophodytes cucullatus): Regular

Summer: rare resident; lakes and rivers

Migration: late March - summer - late November

COMMON MERGANSER (Mergus merganser): Regular

Summer: uncommon resident; lakes and rivers

Migration: mid-Mareh - summer - mid-December

Winter: uncommon visitor on Lake Superior

RED-BREASTED MERGANSER (Mergus serrator): Regular

Summer: uncommon resident; Lake Superior only

Migration: late March - summer - mid-December

Winter: rare visitor on Lake Superior

Family CATHARTIDAE: American Vultures

TURKEY VULTURE (Cathartes aura): Regular

Summer: uncommon resident; forests

Migration: early April - summer - late October

Family ACCIPITRIDAE: Kites, Hawks, Eagles and Harriers

GOSHAWK (Accipter gentilis): Regular

Summer: rare resident; forests 
Migration: mid-March - summer - early December Winter: rare visitor

SHARP-SHINNED HAWK (Accipiter striatus): Regular

Summer: rare resident; forests

Migration: late March - summer - late November

Winter: one record from Cook County $(1 / 1 / 77)$

COOPER'S HAWK (Accipter cooperii): Regular

Summer: very rare resident; forests

Migration: late March - summer - early November

RED-TAILED HAWK (Buteo jamaicensis): Regular

Summer: rare resident; forests

Migration: late March - summer - early December

Winter: rare visitor

BROAD-WINGED HAWK (Buteo platypterus): Regular

Summer: fairly common resident; forests

Migration: early April - summer - mid-October

ROUGH-LEGGED HAWK (Buteo lagopus): Regular

Migration: mid-September - winter - mid-May

Winter: rare visitor

GOLDEN EAGLE (Aquila chrysaetos): Regular

Migration: mid-September - winter - mid-April

Winter: occasional visitor

BALD EAGLE (Haliaeetus leucocephalus): Regular

Summer: rare resident; lakes and lakeshores (fairly common - along the Canadian border

Migration: late February - summer - late December

Winter: occasional visitor

MARSH HAWK (Circus cyaneus): Regular

Summer: rare resident; marshes and bogs

Migration: mid-March - summer - late November

\section{Family PANDIONIDAE: Osprey}

OSPREY (Pandion haliaetus): Regular

Summer: uncommon resident; lakes and lakeshores

Migration: mid-April — summer - late October

\section{Family FALCONIDAE: Fälcons}

GYRFALCON (Falco rusticolus): Occasional

Records: there are two records from the North Shore in Cook County $(11 / 5 / 66 ; 2 / 12 / 66)$. 
PEREGRINE FALCON (Falco peregrinus): Regular

Summer: former resident on the North Shore and in the Boundary

Waters Canoe Area; extirpated by the early 1960's

Migration: late March through late May; late August through mid-November

MERLIN (Falco columbarius): Regular

Summer: very rare resident; forests, especially islands and lakeshores

Migration: early April - summer - late October

Winter: occasional in winter

AMERICAN KESTREL (Falco sparverius): Regular

Summer: Uncommon resident; forest openings and fields (fairly common - logged areas)

Migration: mid-March - summer - late October

\section{Family TETRAONIDAE: Grouse and Ptarmigan}

SPRUCE GROUSE (Canachites canadensis): Regular

Permanent: rare resident; coniferous forests

RUFFED GROUSE (Bonasa umbellus): Regular

Permanent: uncommon resident; forests (fairly

common - deciduous forest)

WILLOW PTARMIGAN (Lagopus lagopus): Accidental

Records: during the winter of 1933-34 an influx occurred in the Ely area

SHARP-TAILED GROUSE (Pedioecetes phasianellus): Accidental

Records: one at Grand Marais on February 4, 1968; formerly in farmland north and west of Virginia, 1973

\section{Family PHASIANIDAE: Quails and Pheasants}

CHUKAR (Alectoris chukar): Extirpated?

Permanent: resident at Ely where a population remained from introductions in the 1940's near the abandoned open-pit iron mines until the mid 1970's when the pit began to flood; last seen on July 16, 1977

\section{Family RALLIDAE: Rails, Gallinules and Coots}

SORA (Porzana carolina): Regular

Summer: very rare resident; marshes

Migration: late April - summer - mid-October

YELLOW RAIL (Coturnicops noveboracensis): Occasional

Summer: one record from Hook Lake, St. Louis County on July 3, 1975

AMERICAN COOT (Fulica americana): Regular

Summer: occasional visitor; lakes 
Migration: early April through late May; mid-September through late November

\section{Family CHARADRIIDAE: Plovers and Turnstones}

SEMIPALMATED PLOVER (Charadrius semipalmatus): Regular

Migration: early May through mid-June; mid-July through late September PIPING PLOVER (Charadrius melodus): Occasional

Migration: late April through late May; late July through mid-September

KILLDEER (Charadrius vociferus): Regular

Summer: uncommon resident; forest openings and fields

Migration: late March - summer - mid-November

AMERICAN GOLDEN PLOVER (Pluvialis dominica): Regular

Migration: early May through early June; late August through early November

BLACK-BELLIED PLOVER (Pluvialis squatarola): Regular

Migration: early May through mid-June; mid-August through early November

RUDDY TURNSTONE (Arenaria interpres): Regular

Migration: early May through mid-June; late July through late September

\section{Family SCOLOPACIDAE: Woodcock, Snipe and Sandpipers}

AMERICAN WOODCOCK (Philohela minor): Regular

Summer: uncommon resident; brushy forest openings (common logged areas, forest openings, alder swales)

Migration: late March - summer - late October

COMMON SNIPE (Capella gallinago): Regular

Summer: uncommon resident; fields and wet, grassy forest openings

Migration: late March - summer - early November

WHIMBREL (Numenius phaeopus): Regular

Migration: mid-May through mid-June; late August through late September

UPLAND SANDPIPER (Bartramia longicauda): Regular

Summer: very rare resident; fields in western part of national forest

Migration: late April - summer - mid-August

SPOTTED SANDPIPER (Actitis macularia): Regular

Summer: uncommon resident; lake and river shorelines

Migration: late April - summer - mid-October

SOLITARY SANDPIPER (Tringa solitaria): Regular

Migration: late April through early June; early July through mid-October 
GREATER YELLOWLEGS (Tringa melanoleucus): Regular

Migration: mid-April through late May; early July through early November

LESSER YELLOWLEGS (Tringa flavipes): Regular

Migration: mid-April through late May; early July through late October

RED KNOT (Calidris canutus): Regular

Migration: late May through mid-June; late July through mid-September

PURPLE SANDPIPER (Calidris maritima): Accidental

Records: one collected at Grand Marais, December 20, 1966

PECTORAL SANDPIPER (Calidris melanotos): Regular

Migration: mid-April through early June; mid-July through late October

WHITE-RUMPED SANDPIPER (Calidris fuscicollis): Regular

Migration: mid-May through mid-June; mid-July through

mid-September

BAIRD'S SANDPIPER (Calidris bairdii): Regular

Migration: late April through early June; mid-July through late September

LEAST SANDPIPER (Calidris minutilla): Regular

Migration: early May through early June; early July through mid-October

DUNLIN (Calidris alpina): Regular

Migration: early May through mid-June; mid-July through late October

SEMIPALMATED SANDPIPER (Calidris pusillus): Regular

Migration: early May through mid-June; mid-July through early October

WESTERN SANDPIPER (Calidris mauri): Occasional

Migration: May; August

SANDERLING (Calidris alba): Regular

Migration: early May through mid-June; mid-July through late October

SHORT-BILLED DOWITCHER (Limnodromus griseus): Regular

Migration: mid-May through early June; early July through mid-September

LONG-BILLED DOWITCHER (Limnodromus scolopaceus): Regular

Migration: mid-May through early June; mid-July through late September

STILT SANDPIPER (Micropalama himantopus): Regular

Migration: May; early July through late September

BUFF-BREASTED SANDPIPER (Tryngites subruficollis): Regular

Migration: May; late July through late September

\section{Family PHALAROPODIDAE: Phalaropes}

NORTHERN PHALAROPE (Lobipes lobatus): Occasional 
Migration: May; late July through late September

Family STERCORARIIDAE: Jaegers

LONG-TAILED JAEGER (Stercorarius longicaudus): Accidental

Records: one seen at Dyer's Lake, Cook County on November 16 or

17,1934

\section{Family LARIDAE: Gulls and Terns}

GLAUCOUS GULL (Larus hyperboreus): Regular

Migration: early November - winter - late May

Winter: uncommon visitor on Lake Superior

HERRING GULL (Larus argentatus): Regular

Summer: fairly common resident; lakes

Migration: mid-March - summer - late November

Winter: common visitor on Lake Superior

THAYER'S GULL (Larus thayeri): Regular

Migration: mid-November - winter - early May

Winter: rare visitor on Lake Superior

RING-BILLED GULL (Larus delawarensis): Regular

Migration: late March through late May; mid-August through early December

BONAPARTE'S GULL (Larus philadelphia): Regular

Summer: occasional visitor; lakes

Migration: mid-April through early June; late July through late November

IVORY GULL (Pagophila eburnea): Accidental

Records: two records from Lake Superior at the Onion River $(10 / 28 / 70)$ and Grand Marais (about 12/1-20/76)

COMMON TERN (Sterna hirundo): Occasional

Migration: early May through early June; early August through late September

CASPIAN TERN (Sterna caspia): Occasional

Summer: occasional visitor on Lake Superior

Migration: early May through early June; late July through late September

BLACK TERN (Chlidonias niger): Regular

Summer: very rare resident (Ely area from the Echo Trail east to

Basswood Lake); marshy lakes

Migration: early May - summer - late September

\section{Family COLUMBIDAE: Pigeons and Doves}

ROCK DOVE (Columba livia): Regular 
Permanent: rare and local resident; settlements only

MOURNING DOVE (Zenaida macroura): Regular

Summer: very rare resident; fields and settlements on North Shore and western part of national forest

Migration: late March - summer - late November

PASSENGER PIGEON (Ectopistes migratorius): Extinct

Records: the last reliable observations for the national forest were in Cook

County in 1879

Family CUCULIDAE: Cuckoos and Anis

BLACK-BILLED CUCKOO (Coccyzus erythropthalmus): Regular

Summer: uncommon resident; forests and forest edges

Migration: mid-May — summer — mid-September

\section{Family TYTONIDAE: Barn Owls}

BARN OWL (Tyto alba): Accidental

Records: pair observed at Lutsen in the summer of 1953

\section{Family STRIGIDAE: Typical Owls}

GREAT HORNED OWL (Bubo virginianus): Regular

Permanent: uncommon resident, forests

SNOWY OWL (Nyctea scandiaca): Regular

Migration: mid-October - winter - early May

Winter: rare visitor

HAWK OWL (Surnia ulula): Regular

Migration: early October - winter - early May

Winter: very rare visitor except in irregular invasions

BARRED OWL (Strix varia): Regular

Permanent: uncommon resident; forests

GREAT GRAY OWL (Strix nebulosa): Regular

Permanent: very rare resident (breeding needs confirmation); coniferous bogs and forests

Winter: very rare visitor except in irregular invasions

LONG-EARED OWL (Asio otus): Regular

Summer: very rare resident (breeding needs confirmation); forests

Migration: mid-April - summer - early December

SHORT-EARED OWL (Asic flammeus): Regular

Summer: very rare resident (breeding needs confirmation); marshes

Migration: mid-March - summer - early December 
BOREAL OWL (Aegolius funereus): Regular

Summer: very rare resident; coniferous forests

Migration: early November - winter - mid-April

Winter: very rare visitor except in irregular invasions, 66 recorded in winter 1977-1978

SAW-WHET OWL (Aegolius acadicus): Regular

Summer: uncommon resident; forests

Migration: mid-March - summer - mid-November

Winter: occasional visitor

Family CAPRIMULGIDAE: Goatsuckers

WHIP-POOR-WILL (Caprimulgus vociferus): Regular

Summer: very rare resident; forests

Migration: early May - summer - mid-September

COMMON NIGHTHAWK (Chordeiles minor): Regular

Summer: uncommon resident; rocky forest openings and settlements

Migration: early May - summer - mid-September

\section{Family APODIDAE: Swifts}

CHIMNEY SWIFT (Chaetura pelagica): Regular

Summer: very rare resident except locally in towns; old growth deciduous

(northern hardwood type) forests and settlements

Migration: early May - summer - mid-September

\section{Family TROCHILIDAE: Hummingbirds}

RUBY-THROATED HUMMINGBIRD (Archilochus colubris): Regular Summer: uncommon resident; forest openings and settlements Migration: early May - summer - early October

\section{Family ALCEDINIDAE: Kingfishers}

BELTED KINGFISHER (Megaceryle alcyon): Regular Summer: uncommon resident; lake and river shorelines Migration: early April - summer - late October

\section{Family PICIDAE: Woodpeckers}

COMMON FLICKER (Colaptes auratus): Regular

Summer: common resident; forest edges and openings

Migration: early April - summer - early November

PILEATED WOODPECKER (Dryocopus pileatus): Regular

Permanent: uncommon resident; old growth forests 
RED-HEADED WOODPECKER (Melanerpes erythrocephalus): Regular Summer: very rare resident; forest openings and settlements (North

Shore and western part of national forest)

Migration: late April - summer - early October

YELLOW-BELLIED SAPSUCKER (Sphyrapicus varius): Regular

Summer: common resident; forests

Migration: early April - summer - late October

HAIRY WOODPECKER (Picoides villosus): Regular

Permanent: uncommon resident; forests and forest openings

DOWNY WOODPECKER (Picoides pubescens): Regular

Permanent: fairly common resident; forests

BLACK-BACKED THREE-TOED WOODPECKER (Picoides arcticus):

Regular

Permanent: rare resident; coniferous forests and burns

Migration: mid-September - winter - late April

Winter: irregular invasions

NORTHERN THREE-TOED WOODPECKER (Picoides tridactylus): Regular

Permanent: very rare resident (breeding needs confirmation); coniferous forests and burns

Migration: late September - winter - late March

Winter: irregular invasions

\section{Family TYRANNIDAE: Tyrant Flycatchers}

EASTERN KINGBIRD (Tyrannus tyrannus): Regular

Summer: uncommon resident; fields and forest openings (including water)

Migration: early May - summer - mid-September

WESTERN KINGBIRD (Tyrannus verticalis): Occasional Migration: May; mid-August through mid-September

SCISSOR-TAILED FLYCATCHER (Muscivora forficata): Accidental

Records: one at Lutsen on November 16, 1972

GREAT CRESTED FLYCATCHER (Myiarchus crinitus): Regular

Summer: rare resident (mostly North Shore and western part); forests

Migration: mid-May - summer - late September

EASTERN PHOEBE (Sayornis phoebe): Regular

Summer: rare resident; river shores and settlements

Migration: mid-April - summer - early October

YELLOW-BELLIED FLYCATCHER (Empidonax flaviventris): Regular Summer: uncommon resident; coniferous forests and bogs

Migration: mid-May - summer — mid-September 
ALDER FLYCATCHER (Empidonax alnorum): Regular Summer: fairly common resident; swamps and bogs Migration: mid-May - summer - late September

LEAST FLYCATCHER (Empidonax minimus): Regular Summer: common resident; forests

Migration: early May - summer - late September

EASTERN WOOD PEWEE (Contopus virens): Regular

Summer: fairly common resident; forests

Migration: mid-May - summer - late September

OLIVE-SIDED FLYCATCHER (Nuttallornis borealis): Regular

Summer: uncommon resident; coniferous forest openings

Migration: mid-May - summer — mid-September

\section{Family ALAUDIDAE: Larks}

HORNED LARK (Eremophila alpestris): Regular

Summer: very rare and local resident; fields (airports)

Migration: mid-February through mid-April; late September through mid-November

\section{Family HIRUNDINIDAE: Swallows}

TREE SWALLOW (Iridoprocne bicolor): Regular

Summer: fairly common resident; settlements and forest openings

(including water)

Migration: mid-April - summer - late September

BANK SWALLOW (Riparia riparia): Regular

Summer: rare and local resident; gravel banks and shorelines (usually near settlements)

Migration: early May - summer - early September

ROUGH-WINGED SWALLOW (Stelgidopteryx ruficollis): Regular

Summer: rare and local resident; lake and river shorelines (usually near settlements)

Migration: early May - summer - early September

BARN SWALLOW (Hirundo rustica): Regular

Summer: uncommon resident; shorelines and settlements

Migration: late April - summer - early October

CLIFF SWALLOW (Petrochelidon pyrrhonota): Regular

Summer: rare and local resident; settlements

Migration: early May - summer - mid-September

PURPLE MARTIN (Progne subis): Regular

Summer: uncommon resident; settlements near lakes 
Migration: mid-April — summer - mid-September

Family CORVIDAE: Jays, Magpies and Crows

GRAY JAY (Perisoreus canadensis): Regular

Permanent: uncommon resident; coniferous forests and bogs

BLUE JAY (Cyanocitta cristata): Regular

Summer: common resident; forests

Migration: late April - summer - mid-October

Winter: rare resident

BLACK-BILLED MAGPIE (Pica pica): Occasional

Migration: early October - winter - early May

Winter: occasional visitor

COMMON RAVEN (Corvus corax): Regular

Permanent: fairly common resident; forests (common, in northern part of national forest)

COMMON CROW (Corvus brachyrhynchos): Regular

Summer: fairly common resident; forests, especially near settlements

Migration: late February - summer - early December

Winter: rare visitor, especially around settlements

CLARK'S NUTCRACKER (Nucifraga columbiana): Accidental

Records: three in the fall of $1969(9 / 27 / 69 ; 12 / 6 / 69 ; 12 / 8-18 / 69)$ and one in the fall of $1972(11 / 24-25 / 72)$

Family PARIDAE: Titmice, Verdins and Bushtits

BLACK-CAPPED CHICKADEE (Parus atricapillus): Regular

Permanent: common resident; forests

BOREAL CHICKADEE (Parus hudsonicus): Regular

Permanent: rare resident; coniferous forests and bogs

Family SITTIDAE: Nuthatches

WHITE-BREASTED NUTHATCH (Sitta carolinensis): Regular

Permanent: very rare resident; deciduous forests

Winter: occasional visitor at feeders

RED-BREASTED NUTHATCH (Sitta canadensis): Regular

Permanent: fairly common resident; coniferous forests

Migration: early April - summer - late November

Winter: irregular invasions

\section{Family CERTHIIDAE: Creepers}

BROWN CREEPER (Certhia familiaris): Regular 
Summer: uncommon resident; old growth forests

Migration: late March - summer - mid-November

\section{Family CINCLIDAE: Dippers}

DIPPER (Cinclus mexicanus): Accidental

Records: one on the North Shore (Baptism, Temperence, Poplar, and Cascade Rivers), January 29-April 4, 1970

\section{Family TROGLODYTIDAE: Wrens}

HOUSE WREN (Troglodytes aedon): Regular

Summer: rare resident; forest openings and settlements

Migration: early May - summer - early October

WINTER WREN (Troglodytes troglodytes): Regular

Summer: fairly common resident; brushy forests and swamps

Migration: mid-April - summer - early October

LONG-BILLED MARSH WREN (Cistothorus palustris): Regular

Summer: very rare resident (breeding needs confirmation); marshes

Migration: mid-May - summer - early October

SHORT-BILLED MARSH WREN (Cistothorus platensis): Regular

Summer: rare resident; marshes and grassy openings

Migration: mid-May - summer - mid-September

ROCK WREN (Salpinctes obsoletus): Accidental

Records: one seen at Grand Marais on October 29, 1966

Family MIMIDAE: Mockingbirds and Thrashers

MOCKINGBIRD (Mimus polyglottos): Occasional

Summer: occasional visitor; North Shore settlements

Migration: May; late September through late November

GRAY CATBIRD (Dumetella carolinensis): Regular

Summer: rare resident; brushy forest openings and water edges, also settlements

Migration: early May - summer - early October

BROWN THRASHER (Toxostoma rufum): Regular

Summer: rare resident; brushy forest openings and settlements

Migration: late April - summer - late October

Family TURDIDAE: Thrushes, Solitaires and Bluebirds

AMERICAN ROBIN (Turdus migratorius): Regular

Summer: abundant resident; forest openings and edges, also settlements Migration: late March - summer - late November

Winter: irregular invasions 
VARIED THRUST (Ixoreus naevius): Occasional

Migration: late November - winter - early April

Winter: occasional visitor

WOOD THRUSH (Hylocichla mustelina): Regular

Summer: very rare resident; deciduous forests

Migration: mid-May - summer - early September

HERMIT THRUSH (Catharus guttatus): Regular

Summer: common resident; forests

Migration: mid-April - summer - late October

SWAINSON'S THRUSH (Catharus ustulatus): Regular

Summer: fairly common resident; coniferous forests and bogs

Migration: early May - summer - late October

GRAY-CHEEKED THRUSH (Catharus minimus): Regular

Migration: early May through early June; mid-August through mid-October

VEERY (Catharus fuscescens): Regular

Summer: abundant resident; forests, mostly deciduous

Migration: mid-May - summer - late September

EASTERN BLUEBIRD (Sialia sialis): Regular

Summer: very rare resident (breeding needs confirmation); forest openings and fields

Migration: early April - summer - late October

Winter: occasional visitor

MOUNTAIN BLUEBIRD (Sialia currucoides): Accidental

Records: one at Lutsen, January 20-24, 1971

TOWNSEND'S SOLITAIRE (Myadestes townsendi): Accidental

Records: one at Grand Marais, December 26, 1977 through March, 1978

Family SYLVIDAE: Gnatcatchers and Kinglets

GOLDEN-CROWNED KINGLET (Regulus satrapa): Regular

Summer: fairly common resident; coniferous forests and bogs

Migration: late March - summer - late November

RUBY-CROWNED KINGLET (Regulus calendula): Regular

Summer: fairly common resident; coniferous forests and bogs

Migration: mid-April - summer - late October

\section{Family MOTACILLIDAE: Pipits}

WATER PIPIT (Anthus spinoletta): Regular

Migration: throughout May; mid-September through early November 
Family BOMBYCILLIDAE: Waxwings

BOHEMIAN WAXWING (Bombycilla garrulus): Regular

Migration: late October - winter - mid-April

Winter: rare visitor except in irregular invasions

CEDAR WAXWING (Bombycilla cedrorum): Regular

Summer: common resident; forest edges, also settlements

Migration: mid-May - summer - November

Winter: irregular invasions

Family LANIIDAE: Shrikes

NORTHERN SHRIKE (Lanius excubitor): Regular

Migration: early October - winter - mid-April

Winter: uncommon visitor

Family STURNIDAE: Starlings

STARLING (Sturnus vulgaris): Regular

Summer: rare resident except locally in towns; forest openings

and settlements

Migration: migration timing unknown

Winter: visitor in settlements

Family VIREONIDAE: Vireos

SOLITARY VIREO (Vireo solitarius): Regular

Summer: uncommon resident; coniferous forests

Migration: early May - summer - early October

RED-EYED VIREO (Vireo olivaceus): Regular

Summer: abundant resident; forests, mostly deciduous

Migration: mid-May - summer - early October

PHILADELPHIA VIREO (Vireo philadelphicus): Regular

Summer: rare resident; deciduous forests and swamps

Migration: mid-May - summer - early October

WARBLING VIREO (Vireo giluus): Regular

Summer: very rare resident (breeding needs confirmation away from settlements); deciduous forests and settlements

Migration: mid-May - summer - mid-September

\section{Family PARULIDAE: Wood Warblers}

BLACK-AND-WHITE WARBLER (Mniotilta varia): Regular

Summer: common resident; forests

Migration: early May - summer - early October

GOLDEN-WINGED WARBLER (Vermivora chrysoptera): Regular 
Summer: very rare resident (mostly Babbitt-Hoyt Lakes area); brushy openings

Migration: mid-May - summer - late September

BLUE-WINGED WARBLER (Vermivora pinus): Accidental

Records: one seen on June 11, 1977, on Lake County Highway 7 south of Hare Lake

TENNESSEE WARBLER (Vermivora peregrina): Regular

Summer: uncommon resident; brushy openings, mostly in coniferous forests

Migration: mid-May - summer - early October

ORANGE-CROWNED WARBLER (Nermivora celata): Regular

Migration: late April through late May; mid-August through mid-October

NASHVILLE WARBLER (Vermivora ruficapilla): Regular

Summer: abundant resident; brushy edges and openings in. young

forests and bogs, also mature coniferous forests

Migration: early May - summer - mid-October

NORTHERN PARULA (Parula americana): Regular

Summer: fairly common resident; coniferous forests

Migration: mid-May - summer - late September

YELLOW WARBLER (Dendroica petechia): Regular

Summer: rare resident; brushy edges mostly along water, also settlements

Migration: early May - summer - mid-September

MAGNOLIA WARBLER (Dendroica magnolia): Regular

Summer: fairly common resident; young coniferous forests

Migration: early May - summer - early October

CAPE MAY WARBLER (Dendroica tigrina): Regular

Summer: uncommon resident; coniferous forests and bogs

Migration: early May - summer - early October

BLACK-THROATED BLUE WARBLER (Dendroica caerulescens): Regular

Summer: rare resident; deciduous forests, mostly old growth northern hardwoods

Migration: mid-May - summer - mid-September

YELLOW-RUMPED WARBLER (Dendroica coronata): Regular

Summer: common resident; coniferous forests and bogs

Migration: mid-April - summer - early November

Winter: occasional in early winter (December)

BLACK-THROATED GREEN WARBLER (Dendroica virens): Regular

Summer: fairly common resident; mature forests, both coniferous and deciduous 
Migration: early May - summer - late September

BLACKBURNIAN WARBLER (Dendroica fusca): Regular Summer: fairly common resident; coniferous forests

Migration: early May - summer - late September

CHESTNUT-SIDED WARBLER (Dendroica pensylvanica): Regular

Summer: abundant resident; brushy openings and edges

Migration: early May - summer — late September

BAY-BREASTED WARBLER (Dendroica castanea): Regular

Summer: rare resident; coniferous forests and bogs

Migration: mid-May - summer - late September

BLACKPOLL WARBLER (Dendroica striata): Regular

Migration: mid-May through early June; mid-August through early October

PINE WARBLER (Dendroica pinus): Regular

Summer: very rare resident; mature red or white pine forests

Migration: late April - summer - early October

PALM WARBLER (Dendroica palmarum): Regular

Summer: very rare resident (breeding needs confirmation); open bogs

Migration: late April - summer - mid-October

OVENBIRD (Seiurus aurocapillus): Regular

Summer: abundant resident; forests

Migration: early May - summer - late September

NORTHERN WATERTHRUSH (Seiurus noveboracensis): Regular Summer: uncommon resident; river and lake edges, swamps

Migration: early May - summer - early October

CONNECTICUT WARBLER (Oporornis agilis): Regular

Summer: rare resident; bogs

Migration: mid-May - summer - mid-September

MOURNING WARBLER (Oporornis philadelphia): Regular

Summer: abundant resident; brushy openings and edges

Migration: mid-May - summer - mid-September

COMMON YELLOWTHROAT (Geothylpis trichas): Regular

Summer: common resident; marshes, bogs and brushy water edges

Migration: early May - summer - early October

WILSON'S WARBLER (Wilsonia pusilla): Regular

Summer: very rare resident (breeding needs confirmation); brushy swamps

Migration: mid-May - summer - late September 
CANADA WARBLER (Wilsonia canadensis): Regular

Summer: fairly common resident; brushy forests and swamps

Migration: mid-May - summer - mid-September

AMERICAN REDSTART (Setophaga ruticilla): Regular

Summer: fairly common resident; forests, mostly deciduous

Migration: early May — summer - early October

Family PLOCEIDAE: Weaver Finches

HOUSE SPARROW (Paser domesticus): Regular

Permanent: rare and local resident; settlements only

Family ICTERIDAE: Meadowlarks, Blackbirds and Orioles

BOBOLINK (Dolichonyx oryzivorus): Regular

Summer: rare and local resident; settlements only (fields)

Migration: early May - summer - early September

EASTERN MEADOWLARK (Sturnella magna): Regular

Summer: rare and local resident; settlements only (fields)

Migration: late March - summer - early November

YELLOW-HEADED BLACKBIRD (Xanthocephalus xanthocephalus):

Regular

Summer: very rare resident (Hoyt Lakes area ); marshes

Migration: mid-April - summer - late October

RED-WINGED BLACKBIRD (Agelaius phoeniceus): Regular

Summer: fairly common resident; marshes and water edges

Migration: late March - summer - late November

Winter: occasional in early winter

NORTHERN ORIOLE (Icterus galbula): Regular

Summer: very rare resident except in towns; deciduous forests, also settlements

Migration: mid-May - summer - early September

RUSTY BLACKBIRD (Euphagus carolinus): Regular

Summer: very rare resident (breeding needs confirmation); swamps and brushy water edges

Migration: early April through mid-May; mid-September through late November

Winter: occasional in early winter

BREWER'S BLACKBIRD (Euphagus cyanocephalus): Regular

Summer: rare and local resident; settlements only (fields)

Migration: mid-April - summer - early November 
COMMON GRACKLE (Quiscalus quiscula): Regular Summer: uncommon resident; brushy water edges, also settlements Migration: late March - summer - late November

Winter: occasional in settlements

BROWN-HEADED COWBIRD (Molothrus ater): Regular

Summer: uncommon resident; forest openings

Migration: mid-April — summer - late October

\section{Family THRAUPIDAE: Tanagers}

WESTERN TANAGER (Piranga ludoviciana): Accidental

Records: one seen at Lutsen on May 20, 1967

SCARLET TANAGER (Piranga olivacea): Regular Summer: uncommon resident; deciduous forests Migration: mid-May - summer - late September

Family FRINGILLIDAE: Grosbeaks, Finches, Sparrows and Buntings

CARDINAL (Cardinalis cardinalis): Occasional

Migration: mid-October - winter - late May

Winter: occasional visitor

ROSE-BREASTED GROSBEAK (Pheucticus ludovicianus): Regular

Summer: common resident; deciduous forests

Migration: early May - summer - late October

Winter: one record at Tofte $(1 / 24 / 75)$

INDIGO BUNTING (Passerina cyanea): Regular

Summer: rare resident; forest openings

Migration: mid-May - summer - mid-September

PAINTED BUINTING (Passerina ciris): Accidental

Records: one at Schroeder, May 12-16, 1965

EVENING GROSBEAK (Hesperiphona vespertina): Regular

Summer: fairly common resident; coniferous forests

Migration: early October - winter - late May

Winter: uncommon visitor

PURPLE FINCH (Carpodacus purpureus): Regular

Summer: fairly common resident; forests

Migration: mid-April - summer - late October

Winter: rare visitor

PINE GROSBEAK (Pinicola enucleator): Regular

Migration: mid-October - winter - early April

Winter: common visitor

HOARY REDPOLL (Carduelis hornemanni): Regular 
Migration: late October - winter - mid-April

Winter: rare visitor

COMMON REDPOLL (Carduelis flammea): Regular

Migration: mid-October - winter - late April

Winter: common visitor

PINE SISKIN (Carduelis pinus): Regular

Summer: uncommon resident (irregular); forests

Migration: too erratic to define

Winter: irregular invasions

AMERICAN GOLDFINCH (Carduelis tristis): Regular

Summer: fairly common resident; forest openings, edges and brushy swamps

Migration: early May - summer - early November

Winter: occasional visitor

RED CROSSBILL (Loxia curvirostra): Regular

Summer: very rare resident (breeding needs confirmation); coniferous forests and bogs

Migration: too erratic to define

Winter: irregular invasions

WHITE-WINGED CROSSBILL (Loxia leucoptera): Regular

Summer: irregular visitor; coniferous forests

Migration: too erratic to define

Winter: irregular invasions

RUFOUS-SIDED TOWHEE (Pipilo erythrophthalmus): Occasional

Migration: May

LARK BUNTING (Calamospiza melanocorys): Occasional

Migration: May; early September through early November - North Shore only

SAVANNAH SPARROW (Passerculus sandwichensis): Regular

Summer: very rare resident except locally in fields; grassy openings and fields

Migration: late April - summer - late October

GRASSHOPPER SPARROW (Ammodramus savannarum): Regular

Summer: very rare resident (breeding needs confirmation); grassy openings and fields

Migration: early May - summer - mid-September

LE CONTE'S SPARROW (Ammospiza leconteii): Regular

Summer: very rare resident (breeding needs confirmation); grassy openings and fields

Migration: early May — summer - early October 
SHARP-TAILED SPARROW (Ammospiza caudacuta): Occasional Migration: May

VESPER SPARROW (Pooecetes gramineus): Regular

Summer: very rare resident (breeding needs confirmation); grassy openings and fields

Migration: mid-April - summer - late October

DARK-EYED JUNCO (Junco hyemalis): Regular

Summer: uncommon resident; coniferous forest edges and bogs

Migration: late March — summer - early December

Winter: occasional at feeders

TREE SPARROW (Spizella arborea): Regular

Migration: early April through mid-May; late September through late November

CHIPPING SPARROW (Spizella passerina): Regular

Summer: common resident; coniferous forest edges and bogs, also settlements

Migration: late April - summer - mid-October

CLAY-COLORED SPARROW (Spizella pallida): Regular

Summer: rare resident; brushy fields and openings

Migration: late April - summer - early October

HARRIS' SPARROW (Zonotrichia querula): Regular

Migration: late April through late May; mid-September through

late October

WHITE-CROWNED SPARROW (Zonotrichia leucophyrys): Regular

Migration: late April through early June; early September through

late October

Winter: occasional at feeders (three records)

WHITE-THROATED SPARROW (Zonotrichia albicollis): Regular

Summer: abundant resident; forests and forest openings

Migration: late April - summer - late November

FOX SPARROW (Passerella iliaca): Regular

Migration: early April through mid-May; mid-September through mid-November

LINCOLN'S SPARROW (Melospiza lincolnii): Regular

Summer: very rare resident; open bogs

Migration: late April - summer - late October

SWAMP SPARROW (Melospiza georgiana): Regular

Summer: fairly common resident; brushy swamps and bogs

Migration: late April - summer - late October 
SONG SPARROW (Melospiza melodia): Regular

Summer: common resident; brushy openings and water edges

Migration: late March - summer - early November

LAPLAND LONGGSPUR (Calcarius lapponicus): Regular

Migration: late March through late May; mid-September through early November

Winter: one record for Cook County $(1 / 14 / 75)$

CHESTNUT-COLLARED LONGSPUR (Calcarius ornatus): Accidental

Records: adult male seen on March 20, 1976 near mouth of

Cascade River

SNOW BUNTING (Plectrophenax nivalis): Regular

Migration: early October - winter - mid-May

Winter: rare visitor

\section{SIGHTING INFORMATION WANTED}

Any new sighting information on uncommon or rare species will be appreciated. Please send sighting information to:

Forest Biologist

Superior National Forest

Box 338

Federal Building

Duluth, Minnesota 55801

Additional copies of this brochure may be obtained by writing to the Forest Supervisor at the same address. 


\section{TABLE 1 - ABUNDANCE OF BREEDING RESIDENTS}

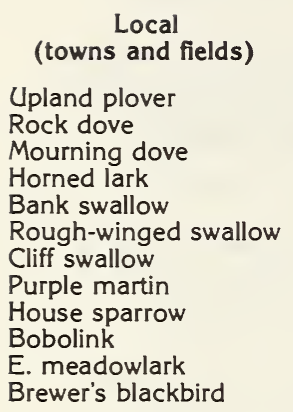

Upland plover

Rock dove

Horned lark

Bank swallow

Cliff swallow

Purple martin

House sparrow

E. meadowlark

Brewer's blackbird

\section{INFREQUENTLY SEEN ON THE FOREST}

Very Rare

Rare

Blue-winged teal

American wigeon

Cooper's hawk

Merlin

Sora

Black tern

Great gray owl

Long-eared owl

Short-eared owl

Boreal owl

Whip-poor-will

Chimney swift

Red-headed woodpecker

Northern three-toed woodpecker

White-breasted nuthatch

Long-billed marsh wren

Wood thrush

Eastern bluebird

Starling

Warbling vireo

Golden-winged warbler

Pine warbler

Palm warbler

Wilson's warbler

Yellow-headed blackbird

Northern oriole

Rusty blackbird

Red crossbill

Savannah sparrow

Grasshopper sparrow

LeConte's sparrow

Vesper sparrow

Marsh hawk
Pied-billed grebe

American bittern

Wood duck

Common goldeneye

Hooded merganser

Goshawk

Sharp-shinned hawk

Red-tailed hawk

Bald eagle

Spruce grouse

Black-backed three-toed woodpecker

Great crested flycatcher

Eastern phoebe

Boreal chickadee

House wren

Short-billed marsh wren

Catbird

Brown thrasher

Philadelphia vireo

Yellow warbler

Black-throated blue warbler

Bay-breasted warbler

Connecticut warbler

Clay-colored sparrow

Indigo bunting

Lincoln's sparrow 


\section{TABLE 1 - ABUNDANCE OF BREEDING RESIDENTS (Continued)}

\section{FOUND THROUGHOUT THE BREEDING SEASON}

\section{Uncommon}

Great blue heron

Mallard

Black duck

Ring-necked duck

Common merganser

Red-breasted merganser

Turkey vulture

Osprey

American kestrel

Ruffed grouse

Killdeer

American woodcock

Common snipe

Spotted sandpiper

Black-billed cuckoo

Great horned owl

Barred owl

Saw-whet owl

Common night hawk

Ruby-throated hummingbird

Belted kingfisher

Pileated woodpecker

Hairy woodpecker

Eastern kingbird

Yellow-bellied flycatcher

Olive-sided flycatcher

Barn swallow

Gray jay

Brown creeper

Solitary vireo

Tennessee warbler

Cape May warbler

Northern waterthrush

Common grackle

Brown-headed cowbird

Scarlet tanager

Pine siskin

Dark-eyed junco
Fairly Common

Common loon

Broad-winged hawk

Herring gull

Downy woodpecker

Eastern wood pewee

Alder flycatcher

Tree swallow

Common raven

Common crow

Red-breasted nuthatch

Winter wren

Swainson's thrush

Golden-crowned kinglet

Ruby-crowned kinglet

Parula warbler

Magnolia warbler

Black-throated green warbler

Blackburnian warbler

Canada warbler

American redstart

Red-winged blackbird

Evening grosbeak

Purple finch

American goldfinch

Swamp sparrow

\section{Common}

Yellow-shafted flicker Yellow-bellied sapsucker Least flycatcher

Blue jay

Black-capped chickadee

Hermit thrush

Cedar waxwing

Black-and-white warbler

Yellow-rumped warbler

Common yellowthroat

Rose-breasted grosbeak

Chipping sparrow

Song sparrow

\section{Abundant}

Robin

Veery

Red-eyed vireo

Nashville warbler

Chestnut-sided warbler Ovenbird

Mourning warbler

White-throated sparrow 
TABLE 2 - FOREST-DWELLING UBIQUITOUS

25 Mile Roadside Count

Guilds

\begin{tabular}{|c|c|c|c|c|}
\hline & Abundance & $\begin{array}{l}\text { Prominence } \\
\text { Value }\end{array}$ & $\begin{array}{l}\text { Mean } \\
\text { Total }\end{array}$ & Foraging \\
\hline Broad-winged hawk & FC & 1 & 1 & predator \\
\hline Sparrow hawk & $u$ & 1 & 1 & predator \\
\hline Ruffed grouse & $u$ & 1 & 1 & ground feeder \\
\hline Killdeer & $u$ & - & - & ground feeder \\
\hline American woodcock & $u$ & - & - & ground feeder. \\
\hline Common snipe & $\cup$ & 2 & 1 & ground feeder \\
\hline Spotted sandpiper & U & - & - & ground feeder \\
\hline Black-billed cuckoo & $u$ & 1 & 1 & foliage gleaner \\
\hline Great horned owl & $u$ & - & - & predator \\
\hline Barred owl & $u$ & - & - & predator \\
\hline Saw-whet owl & U & - & - & predator \\
\hline Common nighthawk & 4 & 1 & 1 & aerial feeder \\
\hline Ruby-throated hummingbird & $u$ & - & - & specialized \\
\hline Belted kingfisher & $u$ & $\therefore$ & - & predator \\
\hline Yellow-shafted flicker & C & 16 & 5 & ground feeder \\
\hline Pileated woodpecker & u & - & - & bark prober \\
\hline Yellow-bellied sapsucker & C & 34 & 9 & bark prober \\
\hline Hairy woodpecker & u & 1 & 1 & bark prober \\
\hline Downy woodpecker & FC & 5 & 2 & bark prober \\
\hline Eastern kingbird & $u$ & 2 & 1 & flycatcher \\
\hline Yellow-bellied flycatcher & 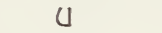 & 11 & 8 & flycatcher \\
\hline Alder flycatcher & FC & 23 & 7 & flycatcher \\
\hline Least flycatcher & C & 56 & 16 & flycatcher \\
\hline Eastern wood pewee & FC & 4 & 2 & flycatcher \\
\hline Olive-sided flycatcher & $U$ & 3 & 2 & flycatcher \\
\hline Tree swallow & $\mathrm{FC}$ & 8 & 4 & aerial feeder \\
\hline Barn swallow & $u$ & 1 & 1 & aerial feeder \\
\hline Gray jay & $u$ & 4 & 2 & variable \\
\hline Blue jay & C & 20 & 7 & variable \\
\hline Common raven & FC & 6 & 3 & variable \\
\hline Common crow & FC & 11 & 4 & variable \\
\hline Black-capped chickadee & C & 4 & 2 & foliage gleaner \\
\hline Red-breasted nuthatch & FC & 5 & 3 & bark gleaner \\
\hline Brown creeper & $u$ & - & - & bark gleaner \\
\hline Winter wren & FC & 19 & 6 & ground gleaner, foliage gleaner \\
\hline American robin & A & 194 & 33 & ground feeder \\
\hline Hermit thrush & C & 35 & 8 & ground feeder \\
\hline Swainson's thrush & FC & 12 & 5 & ground feeder, foliage gleaner \\
\hline Veery & A & 176 & 32 & ground feeder \\
\hline Golden-crowned kinglet & FC & 5 & 2 & foliage gleaner \\
\hline Ruby-crowned kinglet & $\mathrm{FC}$ & 4 & 2 & foliage gleaner \\
\hline Cedar waxwing & C & 7 & 4 & flycatcher, foliage gleaner \\
\hline Solitary vireo & $u$ & 1 & 1 & foliage gleaner \\
\hline Red-eyed vireo & $\bar{A}$ & 252 & 41 & foliage gleaner \\
\hline Black-and-white warbler & C & 21 & 7 & bark gleaner \\
\hline Tennessee warbler & $u$ & 1 & 1 & foliage gleaner \\
\hline Nashville warbler & A & 187 & 33 & foliage gleaner \\
\hline Parula warbler & FC & 5 & 2 & foliage gleaner \\
\hline Magnolia warbler & FC & 49 & 13 & foliage gleaner \\
\hline Cape May warbler & u & 1 & 1 & foliage gleaner \\
\hline Yellow-rumped warbler & $\mathrm{C}$ & 9 & 4 & foliage gleaner \\
\hline Black-throated green warbler & FC & 16 & 6 & foliage gleaner \\
\hline Blackburnian warbler & FC & 12 & 5 & foliage gleaner \\
\hline Chestnut-sided warbler & A & 310 & 50 & foliage gleaner \\
\hline Ovenbird & A & 224 & 39 & ground feeder, foliage gleaner \\
\hline Northern waterthrush & $u$ & 1 & 1 & ground feeder, foliage gleaner \\
\hline Mourning warbler & A & 158 & 27 & ground feeder, foliage gleaner \\
\hline Common yellowthroat & C & 44 & 12 & foliage gleaner \\
\hline Canada warbler & FC & 36 & 10 & foliage gleaner \\
\hline American Redstart & $\mathrm{FC}$ & 60 & 14 & foliage gleaner, flycatcher \\
\hline Red-winged blackbird & FC & 4 & 2 & variable \\
\hline Common grackle & $u$ & 1 & 1 & variable \\
\hline Brown-headed cowbird & $\cup$ & 6 & 2 & variable \\
\hline
\end{tabular}


Habitat

Nesting

tree

cavity

ground

ground

ground

ground

ground

shrub

tree

cavity

cavity

ground

tree

cavity (bank)

cavity

cavity

cavity

cavity

cavity

tree, stub

ground

shrub

tree

tree

tree (conifer)

cavity

ledge structure

tree (conifer)

tree

ledge, tree

tree

cavity

cavity

tree (loose bark)

cavity (roots)

tree

ground

shrub

ground

tree (conifer)

tree (conifer)

tree

tree

tree $\mathcal{E}$ shrub

ground

ground

ground

tree (usnea moss)

tree (small conifer)

tree (conifer)

tree (conifer)

tree (conifer)

tree

shrub

ground

ground

ground $\varepsilon$ shrub

ground $\&$ shrub

ground

tree $\mathcal{E}$ shrub

cattails $\&$ shrub

tree $\mathcal{E}$ shrub

nest parasite
Food

vertebrates

vertebrates, insects

variable

insects

insects

insects

insects

insects

vertebrates

vertebrates

vertebrates

insects

nectar, sap

fish

insects, berries

insects

insects, sap

insects

insects

insects

insects

insects

insects

insects

insects

insects

insects

variable

variable

variable

variable

insects, seeds

insects, seeds

insects

insects

insects, berries

insects, berries

insects, berries

insects, berries

insects

insects

insects, berries

insects

insects

insects

insects

insects

insects

insects

insects

insects

insects

insects

insects

insects

insects

insects

insects

insects

insects

insects, seeds

insects, seeds

insects, seeds forests

forest openings $\mathcal{E}$ fields

forests

forest openings $\varepsilon$ fields

brushy forest openings

wet, grassy forest openings

lakes $\varepsilon$ river shorelines

forest $\mathcal{E}$ forest edges

forests

forests

forests

rocky forest openings

forest openings

lake $\mathcal{E}$ river shorelines

forest edges $\mathcal{E}$ openings

old growth forests

forests

forests $\mathcal{E}$ forest openings

forests

forest openings

coniferous forests $\mathcal{E}$ bogs

swamps \& bogs

forests

forests

coniferous forest openings

forest openings

shorelines

coniferous forests $\varepsilon$ bogs

forests

forests

forests

forests

coniferous forests

old growth forests

brushy forests $\mathcal{E}$ swamps

forest openings $\mathcal{E}$ edges

forests

coniferous forests $\varepsilon$ bogs

deciduous forests

coniferous forests $\varepsilon$ bogs

coniferous forests $\varepsilon$ bogs

forest edges

coniferous forests

deciduous forests

forests

brushy openings in coniferous forests

forests

coniferous forests

young coniferous forests

coniferous forests $\varepsilon$ bogs

coniferous forests $\varepsilon$ bogs

muture forests

coniferous forests

brushy openings $\mathcal{E}$ edges

forests

river $\mathcal{E}$ lake edges $\mathcal{E}$ swamps

brushy openings $\varepsilon$ edges

marshes, bogs $\&$ brushy water edges

brushy forests $\&$ swamps

deciduous forests

marshes $\mathcal{E}$ water edges

brushy water edges

forest openings 
25 Mile Roadside Count

\begin{tabular}{lcccl} 
& Abundance & $\begin{array}{c}\text { Prominence } \\
\text { Value }\end{array}$ & $\begin{array}{c}\text { Mean } \\
\text { Total }\end{array}$ & \multicolumn{1}{c}{ Foraging } \\
Scarlet tanager & U & 1 & 1 & foliage gleaner \\
Rose-breasted grosbeak & C & 65 & 14 & foliage gleaner \\
Evening grosbeak & FC & 7 & 3 & variable \\
Purple finch & FC & 1 & 1 & foliage gleaner \\
Pine siskin & U & 1 & 1 & variable \\
American goldfinch & FC & 7 & 3 & variable \\
Dark-eyed junco & U & 1 & 1 & ground feeder \\
Chipping sparrow & C & 25 & 8 & ground feeder, foliage gleaner \\
White-throated sparrow & A & 481 & 71 & ground feeder, foliage gleaner \\
Swamp sparrow & FC & 10 & 4 & ground feeder, foliage gleaner \\
Song sparrow & C & 60 & 10 & ground feeder, foliage gleaner
\end{tabular}

Table 2 summarizes a variety of information for the forest-dwelling birds. Only those species that are ubiquitous (seen daily or almost daily) throughout the forest during the breeding season are included. Their abundance is coded as follows: A - abundant, C - common, FC - fairly common, U - uncommon. The definitions are given in Chapter 6 . The habitat descriptions are also taken from the annotated list.

\section{PROMINENCE VALUE}

Prominence value is an arbitrary index that is used to "quantify" the classification of a species into a category of commonness. Prominence value was introduced by Beals (1960) in a study of forest bird communities in the Apostle Islands in Wisconsin. Prominence value is calculated by multiplying the density of a species by the square root of its frequency. In this case, density is the number of individuals of a species recorded on a U. S. Fish and Wildlife Service Cooperative Breeding Bird Survey route (Robbins and Van Velzen, 1966) and frequency is the number of stops at which the species was recorded. There are three such routes conducted in or near the Superior National Forest; their location is described in Chapter 6. Ideally, the counts would be evenly distributed throughout the national forest; however, there is a bias for routes in the eastern portion of the forest. The Sawbill Landing roadside count has been run for 4 years, Lockport for 7 years, and Hovland for 3 years.

The reasoning for using the prominence value was based on reducing the impact of "clumping" by birds. As stated by Beals, "Several birds observed at one point are considered less important, for example, than the same number of birds scattered throughout the community." Thus, the prominence value with the square root modification of frequency is a transformation such that " 10 birds found all at one point are about one-third as 'prominent' as one bird found at each of 10 points." The mean total is the average number of individuals of each forest-dwelling species identified on the 25-mile breeding bird survey count.

\section{GUILDS}

These three classifications refer to an ecological concept known as the 
Guilds

\begin{tabular}{ll}
\multicolumn{1}{c}{ Nesting } & \multicolumn{1}{c}{ Food } \\
tree & insects \\
tree & insects, fruit \\
tree (conifer) & seeds, fruit \\
tree (conifer) & seeds, fruit \\
tree (conifer) & seeds \\
tree E shrub & seeds \\
ground & seeds, insects \\
tree E shrub & seeds, insects \\
ground & seeds, insects \\
ground E shrub & seeds, insects \\
ground $\varepsilon$ shrub & seeds, insects
\end{tabular}

Habitat

deciduous forests
deciduous forests
coniferous forests
forests
forests
forest openings $\varepsilon$ edges
coniferous forest edges $\varepsilon$ bogs
coniferous forest edges $\varepsilon$ bogs
forests $\varepsilon$ forest openings
brushy swamps $\varepsilon$ bogs
brushy openings $\varepsilon$ water edges

guild. Like the medieval associations of merchants or craftsmen with common pursuits and interests, birds too can be classified into various guilds. These guilds include foraging, food, and nesting guilds, respectively defined by the way each procures its food, what food it procures, and where it nests. A guild is basically a group of functionally related species that are not necessarily taxonomically related. The objective of classifying species into guilds is to simplify a forest bird community by partitioning species into smaller "workable" units. Theoretically, species that fall into different guilds are not competing with one another for that resource. Species that are in the same guild may be competing for that rescurce but are separated by their requirements for other resources. A resource is anything a species needs to survive and most commonly includes food, shelter, and nest sites. The reason for including the data on guilds in this booklet is twofold: 1) to provide easy reference for researchers in the national forest and 2) to provide an ecological aid for those interested in observing birds in the national forest.

\section{Foraging Guild}

The foraging guild classifies species into groups based on the way food is obtained. "Bark prober" refers to a species, for example most woodpeckers, that drills into the bark of trees in search of insects or sap.

"Bark gleaner" refers to a species that primarily feeds by picking up insects off the bole or branches of trees or shrubs, for example nuthatches and creepers.

A "foliage gleaner" is a species that finds food among the leaves (including needles) of trees and shrubs, for example most vireos and warblers.

A "flycatcher" refers to a species that perches on the outer branches of trees or shrubs and snatches flying insects on the wing, often then returning to the same spot.

"Aerial feeder" refers to species, like swallows, that catch insects while flying over the tree canopy, a field, or a marsh.

"Ground feeder" refers to species that obtain their food by probing, gleaning, or scratching for food on the ground.

A prédator, in this case, is reserved for larger species of birds (e.g., hawks 
and owls) that pursue prey like rodents, large insects, birds, or fish. Strictly speaking, most birds could be classified as predators because so many of them prey on other animals, mainly insects.

\section{Nesting Guild}

The nesting guild classifies species by where they usually place their nests. The words used are self-explanatory. For example, ground means that the species constructs its nest on or a few inches above the ground. The height that nests are placed above the ground varies among individuals of the same species and the term "shrub" or "tree" was used to describe the average situation. H. H. Harrison's "A Field Guide to Birds' Nests" is a good compila-

\section{SELECTED BIBLIOGRAPHY}

Apfelbaum, S. and Haney, A. 1977.

Nesting and foraging activity of the brown creeper in northeastern Minnesota.

Loon 49:78-80.

Anderson, S. H. and Shugart, H. H. 1974.

Habitat selection of breeding birds in an east Tennessee deciduous forest.

Ecology 55:828-837.

Balda, R. P. 1975.

Vegetation structure and breeding bird diversity.

Proceedings of the symposium on management of forest and range habitats for non-game birds, May 5-6, 1975. USDA Forest Service, General Technical Report WO-1, p. 59-86.

Beals, E. 1960.

Forest bird communities in the Apostle lslands of Wisconsin.

Wilson Bull. 72:156-181.

Beer, J. R. 1958.

Changes in ovenbird and mourning warbler abundance at Basswood Lake, Minnesota.

Flicker 30:22-23.

Beer, J. R. and Frenzel, L. D. 1956.

Additional bird records for the Quetico-Superior Wilderness Research Area.

Flicker 28:40

Beer, J. R. and Priewert, F. 1951.

Some observations of the birds of Basswood Lake.

Flicker 23:61-68.

Bergstedt, B. V. 1972.

Breeding-bird census: burned jack pine ridge.

Amer. Birds 27:987-988

Bergstedt, B. V. and Niemi, G. J. 1974.

A comparison of two breeding bird censuses following the Little Sioux fire.

Loon 46:28-33. 
tion of the literature on this subject and was used as a corrective for personal experience.

\section{Food Guild}

The food guilds are also self-explanatory. However, within this group there is also much variation. For example, in the summer the black-capped chickadee feeds extensively on insects, but in the winter it readily accepts sunflower seeds, berries, and suet. The season and the availability of food are of prime importance in determining what and how much of certain types of food a species will accept or use. In general, the food guild listed for a species refers to the season or time the species is resident in the Superior National Forest.

Best, L. B. 1975.

Interpretation errors in the "mapping method" as a census technique.

Auk 92:454-460.

Bond, R. R. 1957.

Ecological distribution of breeding birds in the upland forests of southern Wisconsin.

Ecol. Monog. 27:351-386.

Carbyn, L. N. 1971.

Densities and biomass relationships of birds nesting in boreal forest habitats.

Arctic 24:51-61

Cody, M. L. 1974.

Competition and structure of bird communities.

Princeton: Princeton Univ. Press. 318 pp.

Cody, M. L. and Diamond, J. M., ed. 1975.

Ecology and evolution of communities.

Cambridge, Mass.: The Belknap Press of Harvard Univ. Press. 545 pp.

Cottrille, B. D. 1962.

A search for nesting Cape May warblers.

Flicker 34:38-40.

Cottrille, B. D. 1964.

Lake County nesting records, 1962; Lake County nesting records, 1963.

Loon 36: 22-23.

Curtis, J. T. 1959.

The vegetation of Wisconsin.

Madison: Univ. Wisc. Press. 657 pp.

Dickinson, J. G. 1978.

Comparison of breeding bird census techniques.

Amer. Birds 32:10-13.

Doran, P. and Todd, J. 1976.

Breeding birds on a copper-nickel exploration site.

Loon 48:29-33. 
Doran, P., Todd, J. and Hargy, T. 1977.

Minnamax - avian update for 1976.

Loon 49:70-77.

Emlen, J. T. 1971.

Population densities of birds derived from transect counts.

Auk 88:323-341.

Erskine, A. J. 1974.

Problems associated with bird populations not adequately sampled by the mapping census method.

Acta Ornithol. 24:340-346.

Erskine, A. J. 1977.

Birds in boreal Canada.

Canadian Wildlife Service, Report Series No. 41, 73 pp.

Flaccus, E. and Ohmann, L. E. 1964.

Old growth northern hardwood forests in northeastern Minnesota.

Ecology 45:448-459.

Flack, J. A. D. 1976.

Bird populations of aspen forests in western North America.

Amer. Ornith. Union, Ornith Monogr. 19. 97 pp.

Godfrey, W. E. 1966.

The birds of Canada.

Nat. Mus. Canada Bull. No. 203. 428 pp.

Green, J. C. 1971.

Summer birds of the Superior National Forest, Minnesota.

Loon 43:103-107.

Green, J. C. and Janssen, R. B. 1975.

Minnesota Birds: where, when, and how many.

Minneapolis: Univ. Minn. Press. 217 pp.

Grigal, D. F. and Ohmann, L. F. 1975.

Classification, description, and dynamics of upland plant communities within a

Minnesota wilderness area.

Ecol. Monog. 45:389-407.

Harrison, H. H. 1975.

A field guide to birds' nests.

Boston: Houghton Mifflin Co. 257 pp.

Heinselman, M. L. 1973.

Fire in the virgin forests of the Boundary Waters Canoe Area, Minnesota.

J. Quaternary Res. 3:329-382.

James, F. C. 1971.

Ordinations of habitat relationships among breeding birds.

Wilson Bull. 83:215-235.

James, F. C. and Shugart, H. H., Jr. 1970.

A quantitative method of habitat description.

Audubon Field Notes 24:727-736.

Johnson, C. E. 1920.

Summer bird records from Lake County, Minnesota.

Auk 37:541-551. 
Karr, J. R. and Roth, R. R. 1971.

Vegetation structure and avian diversity in several New World areas.

Amer. Nat. 105:423-436.

Kendeigh, S. C. 1947.

Bird population studies in the coniferous forest biome during a spruce budworm outbreak.

Ontario Dept. of Lands and Forests, Biol. Bull. No. 1:1-100.

Lack, D. 1966.

Population studies of birds.

Oxford: Clarendon Press. 341 pp.

MacArthur, R. H. 1958.

Population ecology of some warblers of northern coniferous forests.

Ecology 39:599-619.

MacArthur, R. H. and MacArthur, J. W. 1961.

On bird species diversity.

Ecology 42:394-398.

MacArthur, R. H. and Wilson, E. O. 1967.

The theory of island biogeography.

Princeton: Princeton Univ. Press. 203 pp.

Marschner, F. J. 1930 (1974).

Map: the original vegetation of Minnesota.

USDA Forest Service, North Central Forest Experiment Station, St. Paul.

Mattsson, J. P. and Grewe, A. H., Jr. 1976.

Bald eagle nesting in the Superior National Forest.

USDA Forest Service, Research Note NC-198. 2 pp.

Morris, R. F., Cheshire, W. F., Miller, C. A. and Mott, D. G. 1958.

The numerical response of avian and mammalian predators during a gradation of the spruce budworm.

Ecology 39:487-494.

Morse, D. H. 1968.

A quantitative study of foraging of male and female spruce-woods warblers.

Ecology 49:779-784.

Niemi, G. J. 1975.

Burned jack pine ridge $l$.

Amer. Birds 29:1106-1107.

Niemi, G. J. 1975.

Burned jack pine ridge 11 .

Amer. Birds 29:1107

Niemi, G. J. 1977.

Habitat alteration: its effect on avian composition and habitat selection.

M. S. Thesis, U. of Minn., Duluth. 110 pp.

Niemi, G. J. 1978.

Breeding birds of burned and unburned areas in northern Minnesota.

Loon 50:73-84.

Odum, E. P. 1971.

Fundamentals of Ecology.

Philadelphia: W. B. Saunders Co. 574 pp. 
Ohmann, L. R. and Ream, R. R. 1971.

Wilderness ecology: virgin plant communities of the Boundary Waters Canoe Area. USDA Forest Service, Research Paper NC-63. 55 pp.

Pfannmuller, L. 1978.

Regional copper-nickel study: song birds of the study area.

Preliminary Draft, July 5, 1978.

Minn. Environmental Quality Board.

Pielou, E. C. 1969.

An introduction to mathematical ecology.

New York: John Wiley E Sons. 286 pp.

Ricklefs, R. E. 1973.

Ecology.

Newton, Mass: Chiron Press. 861 pp.

Robbins, C. S. 1970.

An interna. nal standard for a mapping method in bird census work, recommended by the Inter: ational Bird Census Committee.

Aububon Field Notes 24:722-726.

Robbins, C. S. and Van Velzen, W. T. 1967.

The breeding bird survey, 1966.

U.S. Dept. Int., Fish \& Wildlife Serv., Special Scientific Rpt.-Wildlife No. 102. 43 pp.

Rusterholz, K. A. 1973.

Island bird communities on Burntside Lake, Minnesota.

M. A. Thesis, Univ. Wis., Madison.

Siderits, K. 1977.

Bald Eagle and Osprey report, 1977, Superior National Forest.

Loon 49:235-236.

Siderits, K. and Radtke, R. 1977.

Enhancing forest wildlife habitat through diversity.

Trans. 42nd N. Amer. Wildl. and Nat. Res. Conf., pp. 425-434.

Wildl. Management Instutute.

Smith, K. C. 1977.

Distribution of summer birds along a forest moisture gradient in an Ozark watershed. Ecology 58:810-819.

Sturges, F. W., Holmes, R. T. and Likens, G. E. 1974.

The role of birds in nutrient cycling in a northern hardwoods ecosystem.

Ecology 55:149-155.

Swanson, G. 1940.

Wildlife in the canoe country.

Flicker 40:24-28.

Swedenborg, E. D. 1939.

Summer birds of the Lake Vermilion region.

Flicker 11-14-16.

Todd, J. and Doran, P. 1976.

A preliminary study of summer Parulids near Babbitt, Minnesota.

Loon 48:6-10. 
Whittaker, R. H. 1970.

Communities and ecosystems.

Toronto: MacMillan. 158 pp.

Wiens, J. A. 1969.

An approach to the study of ecological relationships among grassland birds.

Amer. Ornith. Union, Ornith. Monogr. 8. 93 pp.

Wiens, J. A. 1975.

Avian communities, energetics, and functions in coniferous forest habitats.

Proceedings of the symposium on management of forest and range habitats for nongame birds, May 5-6, 1975.

USDA Forest Service, General Technical Report WO-1, p. 226-265.

Willson, M. F. 1974.

Avian community organization and habitat structure.

Ecology 55:1017-1029.

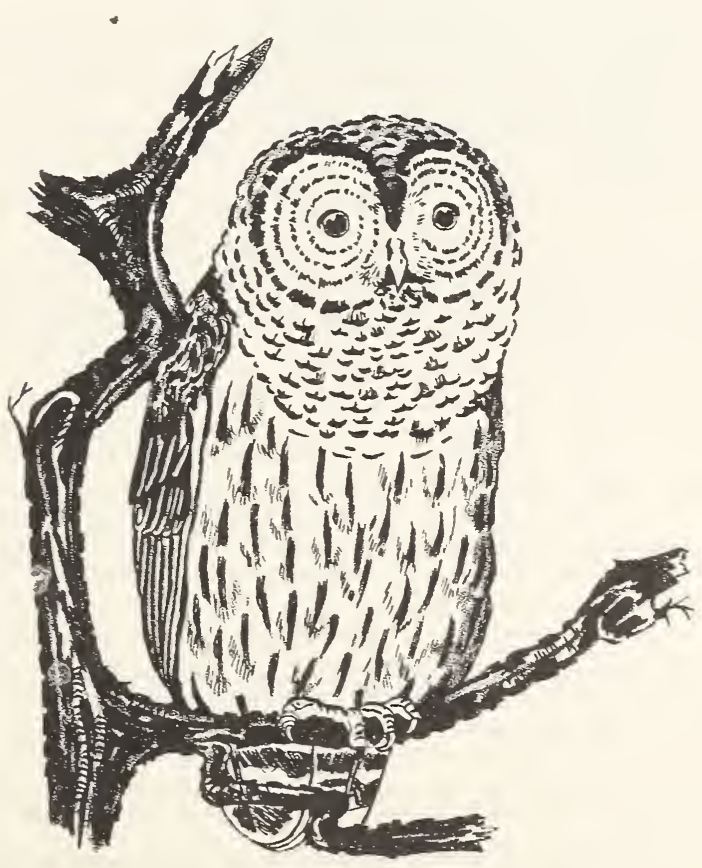

BARRED OWL 
NOTES 


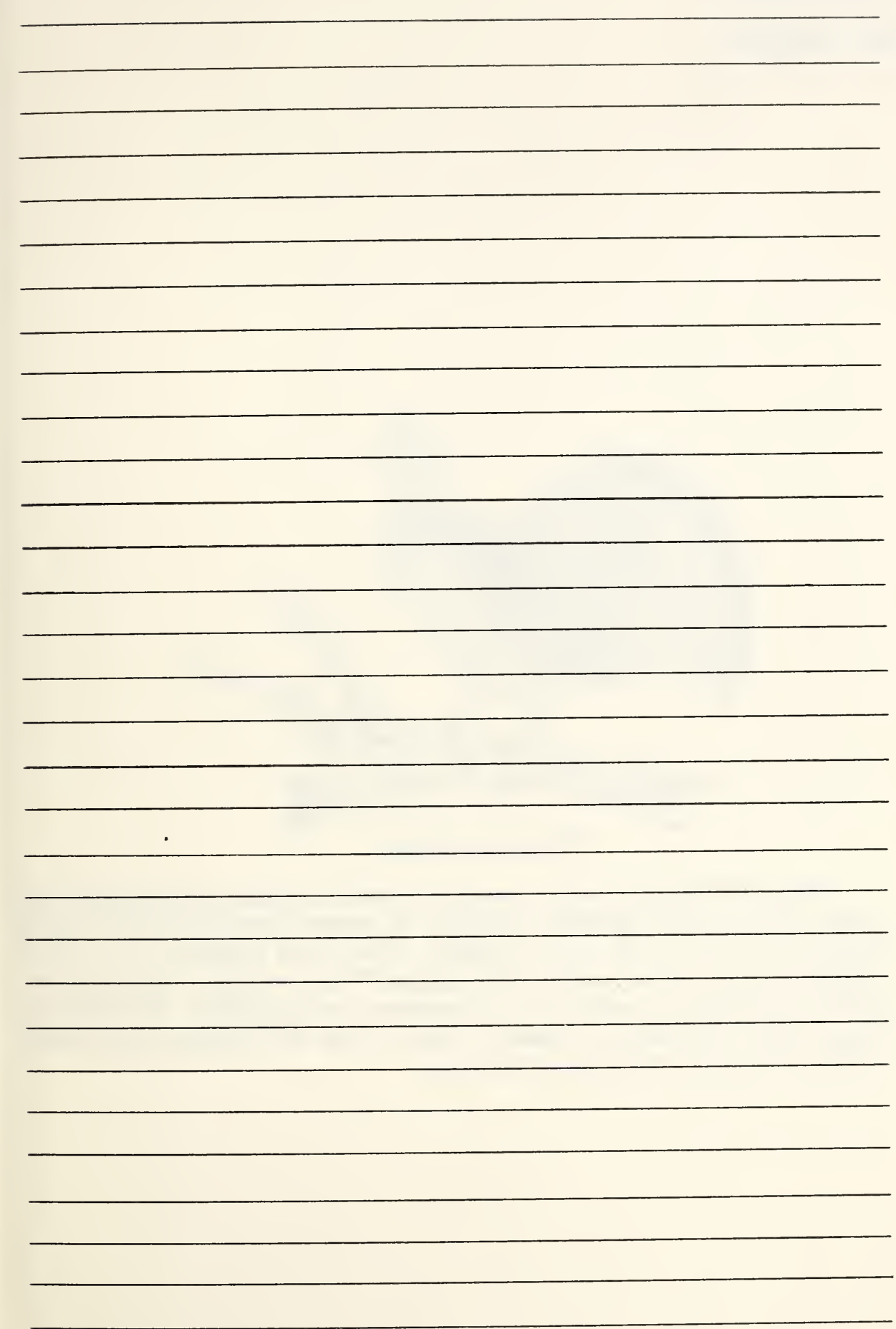


National Forests provide a variety of uses, products, and pleasures for people. They were originally established to protect watersheds and supply timber, and they still do. But in addition, these forest lands are now rich in wildlife, forage, and recreation opportunities. These and other uses are managed by the Forest Service, U. S. Department of Agriculture. Specialists in many fields coordinate and balance uses so that all Americans will receive maximum benefits throughout the years. 


\section{$R 0000260375$}

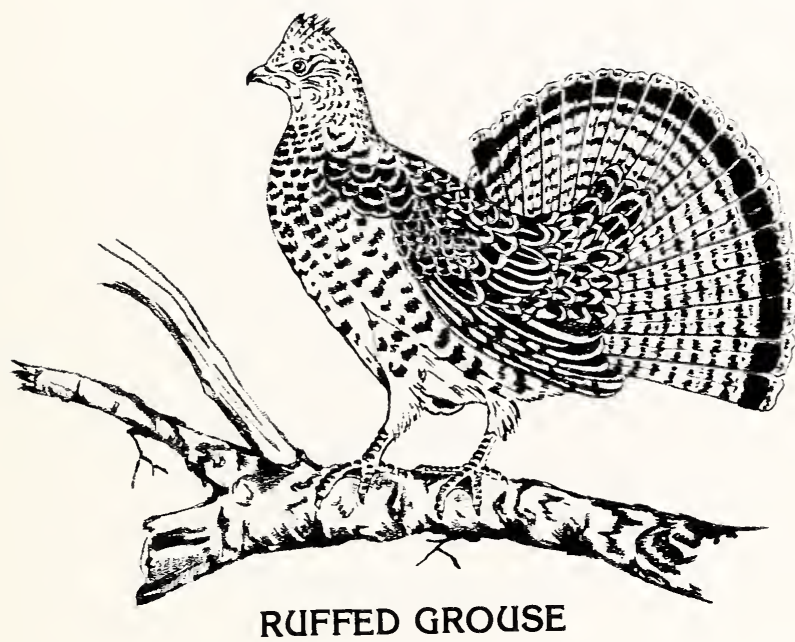




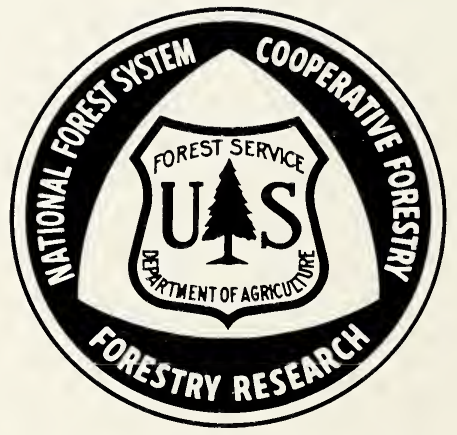

Superior National Forest

Forest Service U.S. Department of Agriculture 